\title{
Export Commodity Production and Broad-based Rural Development: Coffee and Cocoa in the Dominican Republic
}

\author{
by \\ Paul B. Siegel \\ Consultant, World bank, Washington, DC \\ psiegel@worldbank.org \\ and \\ Jeff Alwang \\ Professor, Virginia Tech, VA \\ alwangi@vt.edu \\ Prepared for
Agriculture and Rural Development Department (ARD) \\ and \\ Latin American and the Caribbean Regional Office \\ The World Bank
}

\begin{abstract}
An estimated 80,000-100,000 Dominican farmers produce coffee and cocoa, nearly $40 \%$ of all agricultural producers. The sectors also provide employment for tens of thousands of field laborers and persons employed in linked economic activities. The majority of coffee and cocoa producers are small-scale and most are located in environmentally sensitive watersheds. Recent trends in international commodity markets have challenged the survival of both sectors. Production is characterized by low yields and uneven quality, while periodic hurricanes have contributed to a lackluster and unstable record of output and exports. Despite these conditions, most experts acknowledge the fact that appropriate agro-ecological conditions exist in Dominican Republic for production of high-quality coffee and cocoa. To be competitive and sustainable, some changes must take place in the coffee and cocoa sectors. The objective of this study is to provide an overview of the coffee and cocoa sectors, to identify major problems, and to suggest possible strategies to deal with these problems. The authors conclude that if the objectives of the government are poverty reduction, environmental protection and overall well-being of rural society, it is critical to move beyond a commodity-specific approach to a broader rural development focus on households, regions and environments where coffee and cocoa are currently being grown.
\end{abstract}

KEY WORDS: Dominican Republic, coffee, cocoa, rural development.

World Bank Policy Research Working Paper 3306, May 2004

The Policy Research Working Paper Series disseminates the findings of work in progress to encourage the exchange of ideas about development issues. An objective of the series is to get the findings out quickly, even if the presentations are less than fully polished. The papers carry the names of the authors and should be cited accordingly. The findings, interpretations, and conclusions expressed in this paper are entirely those of the authors. They do not necessarily represent the view of the World Bank, its Executive Directors, or the countries they represent. Policy Research Working Papers are available online at http://econ.worldbank.org. 


\title{
CURRENCY EQUIVALENTS
}

Currency Unit

US\$1

US\$1

\section{WEIGHTS AND MEASURES}

1 hectare (ha)

1 metric ton (ton)

1 quintal (qq)
$=$

$=$

$=$
Dominican Republic Peso (RD\$)

17.0 (July 2002)

27.1 (May 2003)

\author{
ABBREVIATIONS AND ACRONYMS \\ ADOCAFES \\ $A F D$ \\ AGRODOSA \\ AIRAC \\ CAS \\ CATIE \\ CEDAF \\ CEDOPEX \\ CODOCAFE \\ CNC \\ CRMG \\ CONACADO \\ DEFINPRO \\ DR \\ FEDECARES \\ GoDR \\ GTZ \\ IAD \\ $I A D B$ \\ ICP \\ IDA \\ IDIAF \\ INDUBAN \\ INESPRE \\ JAD \\ NYBOT \\ SEA \\ UNACAFEN \\ USAID \\ Dominican Specialty Coffee Association \\ Agence Francaise de Developpement (FDA in English) \\ Asegudora Agropecuria Dominicana, S.A. \\ Asociacion de Insituciones Rurales de Ahorro y Credito \\ Country Assistance Strategy \\ Centro Agronomico Tropical de Investigación y Ensenanza \\ Centro Para el Desarrollo Agropecuario y Forestal \\ Dominican Center for the Promotion of Exports \\ Consejo Dominicano del Café (Coffee Council) \\ Comisión Nacional del Cacao \\ Commodity Risk Management Group (World Bank) \\ Confederación Nacional de Cacaocultores Dominicanos \\ Department of Project Finance \\ Dominican Republic \\ Federación de Caficultores del Sur \\ Government of Dominican Republic \\ German Technical Cooperation Agency \\ Instituto Agrario Dominicano \\ InterAmerican Development Bank \\ International Coffee Partners \\ International Development Agency, World Bank \\ Instituto Dominicano de Investigacion Agropecuria y Forestal \\ Industrias Banilejas \\ Institute for Price Stabilization \\ Junta Agroempresarial Dominicana \\ New York Board of Trade \\ Secretariat of Agriculture \\ Unión de Asociaciones de Caficultores del Norte \\ United States Agency for International Development
}




\title{
CONTENTS
}

\author{
ABSTRACT
}

EXECUTIVE SUMMARY

INTRODUCTION

\begin{tabular}{|c|c|}
\hline CHAPTER I & $\begin{array}{l}\text { RECENT MACROECONOMIC and AGRICULTURAL SECTOR } \\
\text { PERFORMANCE and POLICIES }\end{array}$ \\
\hline Section A & Macroeconomic Performance \\
\hline Section A.1 & GDP and Exports \\
\hline Section A.2 & Exchange Rates and Inflation \\
\hline Section B & Population, Per Capita GDP, and Poverty \\
\hline Section B.1 & Population \\
\hline Section B.2 & Per Capita GDP and Poverty \\
\hline Section $\mathrm{C}$ & Overview of Factor Markets \\
\hline Section C.1 & Labor Markets and Human Capital \\
\hline Section C.2 & Land Distribution and Land Titles \\
\hline Section C. 3 & Financial Sector \\
\hline Section D & Recent Agricultural Sector Performance and Policies \\
\hline Section D.1 & Overview of Performance of Agricultural Sector \\
\hline Section D.2 & Recent Agricultural Policies \\
\hline Section D.3 & Public Institutions \\
\hline Section D.4 & International Agencies and NGOs \\
\hline Section E. & Agriculture and the Environment \\
\hline CHAPTER II & $\begin{array}{l}\text { RECENT WORLD COFFEE and COCOA PRICES, PRODUCTION, } \\
\text { EXPORTS }\end{array}$ \\
\hline Section A & Recent Coffee Prices, Production, and Exports \\
\hline Section B & Recent Cocoa Prices, Production, and Exports \\
\hline Section C & Comparing the Situation in Coffee and Cocoa Markets \\
\hline CHAPTER III & OVERVIEW of DOMINICAN COFFEE SECTOR \\
\hline Section A & Trends in Coffee Production and Export \\
\hline Section B & Geography and Ecology of Production \\
\hline Section C & Quantities Produced and Exported \\
\hline Section D & Structure of Production \\
\hline Section E & Structure of Post-Harvest Activities, Marketing, and Exports \\
\hline Section E.1 & Post-Harvest Activities \\
\hline Section E.2 & Coffee Intermediaries \\
\hline Section E.3 & Coffee Exporters \\
\hline
\end{tabular}




\author{
Section E.4 Domestic Coffee Market \\ Section E.5 Estimated Marketing Margins \\ Section F Other Coffee-Related Institutions \\ Section F.1 Government \\ Section F.2 International Development Agencies and NGOs \\ Section G Competitiveness of the Dominican Coffee Sector

\section{CHAPTER IV OVERVIEW of DOMINICAN COCOA SECTOR} \\ Section A Trends in Cocoa Production and Export \\ Section B Geography and Ecology of Production \\ Section C Quantities Produced and Exported \\ Section D Structure of Production \\ Section E Structure of Post-Harvest Activities, Marketing, and Exports \\ Section E. 1 Cocoa Intermediaries \\ Section E.2 Cocoa Exporters \\ Section E. 3 Domestic Cocoa Market \\ Section E.4 Estimated Marketing Margins \\ Section F Other Cocoa-Related Institutions \\ Section F.1 Government \\ Section F.2 International Development Agencies and NGOs \\ Section $\mathrm{G} \quad$ Competitiveness of the Dominican Cocoa Sector \\ CHAPTER V CHALLENGES to the DOMINICAN COFFEE and COCOA SECTORS \\ Section A Overview of Strategies for the Coffee Sectors of Central America and Caribbean \\ Section B Challenges Strategies for the Coffee Sectors of Dominican Republic \\ Section B.1 Macro and Agricultural Sector Policies \\ Section B.2 Production and Marketing Issues \\ Section B.3 Land, Labor and Finance Issues \\ Section C Commodity Price and Weather Risks \\ Section D Environmental Issues \\ Section E Conclusion: Towards a Strategy for the Coffee and Cocoa Sectors

\section{REFERENCES}

ANNEX World Bank’s Cocoa and Coffee Project 1982-1989

MAP Agricultural Regions of Dominican Republic 


\section{Acknowledgements}

This report was prepared by Paul B. Siegel and Jeffrey Alwang (consultants).

Panos Varangis (ARD) was the Task Team Leader (TTL).

The authors acknowledge the technical assistance of Erin Bryla (consultant, ARD), who provided some of the background materials used for the report, and also provided helpful comments and suggestions. Additional inputs were received from Bryan Lewin (consultant, ARD), Jorge Tiemier (EDE Consulting), Paul Trupo (USAID-DR). Comments and suggestions were provided by Steve Jaffee (PRMTR) and Francisco Pichon (LCSER)

Some of the information in this report was collected for the Commodity Risk Management Group's Phase II Study on the coffee and cocoa sectors, including the survey of producers. During the team's mission, from May 27 - June 1, 2003, meetings were held with representatives of the coffee and cocoa sectors. These meetings were coordinated with the Coffee Council (Consejo Dominicano del Café) and the Cocoa Department and Cocoa Commission to represent the public and private sectors, producer associations, exporters and processors. The authors thank the participants at these meetings for generously giving of their time and opinions, and to Pedro Pablo Pena (CEDAF) who provided assistance for the team mission to Dominican Republic.

The authors also would like to acknowledge the useful comment by the peer reviewers Donald Larson (DECRG) and Nadim Khouri (LCSER).

Finally, the authors would like to express thanks to Cicely Spooner, Elaine Wylie, and Melissa Williams (ARD) for providing administrative support for this study.

\section{Note from the Authors}

Some inconsistencies exist in Dominican coffee and cocoa data. In some cases, discrepancies result from rounding, use of different units of measure, different reporting years, etc. In other cases, discrepancies and inconsistencies are more difficult to reconcile. The authors have attempted to use consistent data series and reconcile inconsistencies, but this was not always possible. 


\section{Export Commodity Production and Broad-based Rural Development: Coffee and Cocoa in the Dominican Republic}

\section{EXECUTIVE SUMMARY}

In the early 1980s, coffee and cocoa exports from Dominican Republic accounted for about 30$35 \%$ of total exports. By 2000 this figure was closer to 5\%. However, an estimated 80,000100,000 Dominican farmers still produce coffee and cocoa, nearly $40 \%$ of all agricultural producers. The sectors also provide employment for tens of thousands of field laborers and persons employed in linked economic activities. The majority of coffee and cocoa producers are small scale and most are located in environmentally sensitive watersheds. Recent trends in international commodity markets have challenged the survival of both sectors, which are known for their low productivity and low quality beans. Present challenges to the Dominican coffee and cocoa sectors in the $21^{\text {st }}$ century follow decades of high direct and indirect taxes on the sectors, which transferred resources to government coffers. In recent years, these taxes have largely been eliminated and these sectors have increasingly been depending on assistance from Government, international agencies and NGOs for their preservation. Some of this assistance has been provided after damaging hurricanes and some of it as short-term bailouts during periods of price declines.

The coffee and cocoa sectors provide only partial income to most Dominican producers, who tend to have diversified income-generating strategies. Coffee and cocoa sectors have seasonal labor demands and have increasingly faced tightening markets for low-paying low-skill harvest laborers. Coffee and cocoa production, harvesting and marketing have pronounced seasonal cash flows that necessitate financing arrangements. With a problematic rural financial sector and high interest rates, funds for coffee and cocoa producers tend to be constrained. Both the coffee and cocoa sectors are characterized by markets that are highly concentrated and dominated by a small number of exporters. Some of the financing void has been filled by exporters. Financingmarketing arrangements for the Dominican coffee and cocoa sectors requires more in-depth analyses to understand their efficiency and equity.

Most experts acknowledge the fact that appropriate agro-ecological conditions exist in Dominican Republic to produce high-quality coffee and cocoa. Past performance, however, has not lived up to this latent potential. To be competitive and sustainable, some changes must take place in the coffee and cocoa sectors. Faced by many challenges, it is timely to examine these sectors to provide some guidance about their future. The objective of this study is to provide an overview of the coffee and cocoa sectors, to highlight major problems, and to suggest possible strategies to deal with these problems. The authors conclude that if the objectives of the government are poverty reduction, environmental protection and the overall well-being of rural society, it is critical to move beyond a commodity-specific approach to a broader rural development focus on households, regions and environments where coffee and cocoa are currently being grown. While policies and programs can help bolster the economic viability of both commodity sectors, their ultimate sustainability depends on the mosaic of linkages between households and their economic, social and environmental context. 


\section{INTRODUCTION}

In the early 1980s, coffee and cocoa exports from the Dominican Republic accounted for about $30-35 \%$ of total exports. By 2000 this figure was closer to $5 \%$. However, it is estimated that there are still about 80,000-100,00 Dominican coffee and cocoa producers, or about $35-40 \%$ of all Dominican farmers. In addition, there are tens of thousands of laborers and persons employed in linked economic activities. Furthermore, the majority of coffee and cocoa producers are smallscale producers and most coffee and cocoa producing areas are located in environmentally sensitive watersheds. Recent trends in international commodity markets have challenged the existence and sustainability of both the coffee and cocoa sectors, as have periodic hurricanes that have damaged coffee and cocoa plantations. Problems with marketing and financing arrangements in the coffee and cocoa sectors have tended to exacerbate these challenges, which are also associated with low yields and poor quality.

During 2002, the Commodity Risk Management Group (CRMG) of the Agricultural and Rural Development Department prepared a report about the Dominican Republic's coffee and cocoa sectors. The focus of the report was on the appropriateness of piloting commodity price insurance for coffee and/or cocoa producers, and included a survey of producers (see World Bank, 2002a). After preparing the report, and attempting to pursue a pilot commodity price insurance scheme, it was realized that a broader set of issues should be investigated in the coffee and cocoa sectors of the Dominican Republic.

Since the Country Management Unit for the Dominican Republic was beginning to undertake an Agricultural Sector Strategy review, it was thought that a deeper investigation of the coffee and cocoa sectors, particularly in the context of the country's overall macroeconomic and agricultural sector performance and policies, would be a useful contribution to the process of background analyses and policy dialogues.

Thus, this report is an initial attempt to provide some additional analyses and to stimulate policy dialogue for the coffee and cocoa sectors in the Dominican Republic. This report also points out that although considerable data and information are available, there are significant knowledge gaps. This is especially true if the objectives of the government are poverty reduction, environmental protection and maintenance of rural society, which requires that analyses and policy dialogues move beyond a commodity-specific approach to a broader focus on households, regions and environments where coffee and cocoa are currently being grown. While policies and programs can help bolster the economic viability of both commodity sectors, their ultimate sustainability depends on the mosaic of linkages between households and their economic, social and environmental context. And there are still important gaps to fully understanding and appreciating this complex mosaic, and for identifying the appropriate roles for Government, the private sector, international development agencies, and non-governmental organizations (NGOs). 


\section{RECENT MACROECONOMIC and AGRICULTURAL SECTOR PERFORMANCE and POLICIES}

The Dominican Republic is classified as a "middle-income country" with a per-capita GNP of $\$ 1,910$ in 2000 (thereby no longer qualifying for IDA loans). It occupies the eastern part of the island of Hispaniola (which is shared with Haiti), covering some 49,000 square kilometers. It is densely populated by Latin American standards with more than 170 people per square kilometer. While the country is still relatively dependent on agriculture ${ }^{1}$, it is becoming increasingly urbanized. As of 2000, approximately $64 \%$ of the country's 8.6 million people lived in cities. The economy has undergone major structural changes that reflect this increased urbanization. In this section we present an overview of recent macroeconomic and agricultural sector performance and policies. We also present an overview of changes in population, per capita GDP, and poverty, and highlight issues related to factor markets for land, labor and finance.

\section{A Macroeconomic Performance}

In this overview of recent macroeconomic performance, we investigate trends in GDP and exports, and rates of exchange and inflation.

\section{A.1 GDP and Exports}

Economic growth in the Dominican Republic (DR) was erratic in the late 1980s and early 1990s; due largely to policy changes, fluctuations in fast-growing export manufacturing free zones ("maquilas") and tourism and construction sectors, and fluctuations in slow-growing traditional agricultural export crops such as sugar, coffee, cocoa, and tobacco. The global recession spread to the Caribbean region, reducing tourism earnings and slowing investment. Fluctuating energy prices and problems with the national electrical supply system contributed to economic instability. Prospects turned around in the mid-1990s, and through 2000 the Dominican Republic experienced high and stable rates of economic growth - about $8 \%$ per annum (see table I.1), among the highest in Latin America (ECLAC, 2001). Economic growth continued despite the damaging Hurricane Georges that hit the Dominican Republic in September 1998.

Recent growth has been led by exports of goods and services (e.g., manufactured goods, tourism and non-traditional agricultural exports) and growth in construction and communications (often linked to other fast-rowing sectors). This growth followed substantial economic reforms including deregulation of interest rates and foreign exchange, reform of the financial sector, lowering of import quotas and tariffs on agricultural imports, and an increase in public investment. The economic adjustment the country experienced in the early 1990s set the stage for growth later in the decade. However, not all sectors shared in this surge of growth; traditional agricultural enterprises, mining, and non-maquila manufacturing experienced slower growth or decline.

Agricultural growth rates were satisfactory for the 1990s (average annual growth about 2.6\%), but lagged behind the growth of other sectors. As such, the share of agriculture in GDP fell from $12.8 \%$ in 1996 to $11.1 \%$ in 2000 (see table I.2). This path continues a trend of decreasing share of agriculture in GDP. In 1960, agriculture accounted for about $30 \%$ of GDP and this share fell steadily through 2002. Another indication in the relative decline of agriculture is the share of primary exports in total exports. From 1995 to 2000 this share fell from $37 \%$ to $29 \%$ (see table

\footnotetext{
${ }^{1}$ Approximately $11 \%$ of GDP in 2000 came from agriculture.
} 
I.3), led by declines in sugar, coffee and cocoa. In contrast, in 1977-78 agricultural exports accounted for about $70 \%$ of the value of total exports, with coffee and cocoa accounting for about half of agricultural exports (World Bank, 1981).

There is evidence of a slowdown in overall economic growth in Dominican Republic starting in 2001 (Central Bank of Dominican Republic). This decline is due to a combination of internal policy changes such as higher taxes and tighter monetary conditions, decreases in agricultural production due to a drought and decreases in international prices for major agricultural exports, increases in energy imports, along with lower overall demand due to the global recession. Tourism revenue fell dramatically since September 11, 2001. In the first trimester of 2002, economic growth was negative in agriculture $(-7.8 \%)$, tourism $(-11.2 \%)$ and duty free zones ($7.5 \%$ ), pointing to a steep slump in these sectors.

Table I.1: Dominican Republic Gross Domestic Product 1996-2000

\begin{tabular}{|c|c|c|c|c|c|c|c|c|c|}
\hline & \multicolumn{5}{|c|}{ In millions of RD\$, 1970 prices } & \multicolumn{4}{|c|}{ Annual Growth Rates (\%) } \\
\hline & 1996 & 1997 & 1998 & $1999 *$ & $2000 *$ & $\begin{array}{l}1997 / \\
1996\end{array}$ & $\begin{array}{l}1998 / \\
1997\end{array}$ & $\begin{array}{l}1999 / \\
1998\end{array}$ & $\begin{array}{l}2000 / \\
1999\end{array}$ \\
\hline $\begin{array}{l}\text { TOTAL } \\
\text { of which: }\end{array}$ & 4907 & 5314 & 5701 & 6156 & 6633 & 8.3 & 7.3 & 8.0 & 7.8 \\
\hline Agriculture & 630 & 650 & 657 & 702 & 737 & 3.3 & 1.1 & 6.7 & 5.0 \\
\hline - Crops & 314 & 325 & 321 & 336 & 344 & 3.6 & -1.5 & 4.9 & 2.4 \\
\hline - Livestock & 292 & 301 & 305 & 332 & 361 & 3.1 & 1.5 & 8.8 & 8.6 \\
\hline - Forestry, Fishery & 24 & 24 & 32 & 33 & 31 & 1.0 & 31.0 & 4.5 & -4.5 \\
\hline Minerals & 129 & 133 & 112 & 110 & 120 & 3.1 & -15.9 & -1.5 & 9.2 \\
\hline Manufacturing & 858 & 922 & 974 & 1037 & 1130 & 7.5 & 5.7 & 6.4 & 9.0 \\
\hline - Sugar & 48 & 51 & 40 & 30 & 35 & 7.8 & -22.5 & -24.5 & 16.7 \\
\hline - Other & 640 & 683 & 732 & 809 & 881 & 6.6 & 7.3 & 10.5 & 8.9 \\
\hline - Free Zones** & 170 & 188 & 202 & 197 & 213 & 10.6 & 7.6 & -2.5 & 8.0 \\
\hline Other $* * *$ & 3290 & 3609 & 3958 & 4307 & 4646 & 9.7 & 9.7 & 8.8 & 7.9 \\
\hline $\begin{array}{ll}\text { Notes: } & * \text { Data for } 2 \\
& * * \text { Value-a } \\
& * * * \text { Other i } \\
& \text { commu }\end{array}$ & $\begin{array}{l}0,2001 \\
\text { d only. } \\
\text { udes: co }\end{array}$ & 002 are & elimina & & 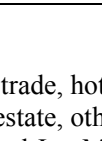 & & (1) & ansport, & \\
\hline
\end{tabular}

Table I.2: Dominican Republic Shares of Gross Domestic Product 1996-2000

\begin{tabular}{|l|l|l|l|l|l|}
\hline & \multicolumn{3}{|c|}{ Percent (\%) Shares } \\
\hline & 1996 & 1997 & 1998 & $1999^{*}$ & $2000^{*}$ \\
\hline TOTAL, of which: & 100 & 100 & 100 & 100 & 100 \\
\hline Agriculture & 12.8 & 12.2 & 11.5 & 11.4 & 11.1 \\
\hline - Crops & 6.4 & 6.1 & 5.6 & 5.5 & 5.2 \\
\hline - Livestock & 5.95 & 5.7 & 5.4 & 5.4 & 5.4 \\
\hline - Forestry, Fishery & 0.5 & 0.5 & 0.6 & 0.5 & 0.5 \\
\hline Minerals & 2.6 & 2.5 & 2.0 & 1.8 & 1.8 \\
\hline Manufacturing & 17.5 & 17.3 & 17.1 & 16.8 & 17.0 \\
\hline - Sugar Refining & 1.0 & 1.0 & 0.7 & 0.5 & 0.5 \\
\hline - Other & 13.0 & 12.8 & 12.8 & 13.1 & 13.3 \\
\hline - Free Zones** & 3.5 & 3.5 & 3.6 & 3.2 & 3.2 \\
\hline Other * & 67.1 & 67.9 & 69.4 & 70.0 & 70.0 \\
\hline
\end{tabular}


Table I.3: Dominican Republic: Value and Shares of Primary Exports 1995-2000

\begin{tabular}{|c|c|c|c|c|c|c|c|c|c|c|c|c|}
\hline & \multicolumn{6}{|c|}{ In US\$ millions } & \multicolumn{5}{|c|}{$\%$ Share of Total Exports } & \\
\hline & 1995 & 1996 & 1997 & 1998 & 1999 & 2000 & 1995 & 1996 & 1997 & 1998 & 1999 & 2000 \\
\hline 1. Primary Exports & 324 & 361 & 403 & 370 & 231 & 276 & $37 \%$ & $38 \%$ & $40 \%$ & $42 \%$ & $29 \%$ & $29 \%$ \\
\hline Of which: & & & & & & & & & & & & \\
\hline Crude Sugar & 103.4 & 145.9 & 175.6 & 66.3 & 65.6 & 70.9 & $12 \%$ & $15 \%$ & $17 \%$ & $8 \%$ & $8 \%$ & $7 \%$ \\
\hline Green Coffee & 81.6 & 63.0 & 66.4 & 64.6 & 14.8 & 20.8 & $9 \%$ & $7 \%$ & $6 \%$ & $7 \%$ & $2 \%$ & $2 \%$ \\
\hline Cocoa Beans & 54.4 & 58.2 & 54.1 & 79.3 & 20.2 & 21.7 & $6 \%$ & $6 \%$ & $5 \%$ & $9 \%$ & $2 \%$ & $2 \%$ \\
\hline Tobacco & 16.8 & 27.5 & 38.7 & 39.8 & 33.2 & 24.2 & $2 \%$ & $3 \%$ & $4 \%$ & $5 \%$ & $4 \%$ & $2 \%$ \\
\hline Banana & 12.0 & 10.0 & 7.6 & 13.0 & 16.6 & 19.3 & $1 \%$ & $1 \%$ & $1 \%$ & $1 \%$ & $2 \%$ & $2 \%$ \\
\hline Coconuts & 6.6 & 6.5 & 4.6 & 6.3 & 6.0 & 6.2 & $1 \%$ & $0.5 \%$ & $0.5 \%$ & $0.5 \%$ & $1 \%$ & $1 \%$ \\
\hline Melons & 3.5 & 4.9 & 3.9 & 4.3 & 7.5 & 10.8 & $0.5 \%$ & $0.5 \%$ & $0.5 \%$ & $0.5 \%$ & $1 \%$ & $1 \%$ \\
\hline Avocado & 3.8 & 4.2 & 2.3 & 5.4 & 7.6 & 6.6 & $0.5 \%$ & $0.5 \%$ & $0.5 \%$ & $0.5 \%$ & $1 \%$ & $1 \%$ \\
\hline Oranges & 2.9 & 2.9 & 2.4 & 2.2 & 1.7 & 1.4 & $0.5 \%$ & $0.5 \%$ & $0.5 \%$ & $0.5 \%$ & $0.5 \%$ & $0.5 \%$ \\
\hline Others & 38.8 & 38.2 & 46.8 & 89.1 & 67.4 & 94.1 & $4 \%$ & $4 \%$ & $5 \%$ & $10 \%$ & $8 \%$ & $10 \%$ \\
\hline $\begin{array}{l}\text { 2. Intermediate } \\
\text { Products }\end{array}$ & 328 & 331 & 312 & 211 & 202 & 286 & $38 \%$ & $35 \%$ & $31 \%$ & $24 \%$ & $25 \%$ & $30 \%$ \\
\hline $\begin{array}{l}\text { 3. Consumption } \\
\text { Products }\end{array}$ & 220 & 253 & 303 & 299 & 372 & 404 & $25 \%$ & $27 \%$ & $30 \%$ & $34 \%$ & $50 \%$ & $42 \%$ \\
\hline 4. Total $(1+2+3)$ & 872 & 946 & 1017 & 880 & 805 & 966 & $100 \%$ & $100 \%$ & $100 \%$ & $100 \%$ & $100 \%$ & $100 \%$ \\
\hline
\end{tabular}

Notes: Data for 2000 is preliminary.

Sugar, Coffee, Cocoa, Tobacco include raw products only.

Source: Central Bank of Dominican Republic (2001).

\section{A.2 Exchange Rates and Inflation ${ }^{2}$}

Economic reforms, including changes in monetary and fiscal policy along with market and trade liberalization, began in 1991. This followed a period of inappropriate fiscal and monetary policies. The previous policies caused inflation rates to rise to about 40-50\% from 1988-1991, and led to distorted exchange rates. In contrast, since 1992, annual inflation rates declined to 4$12 \%$, and there were appropriate adjustments in exchange rates. To stabilize prices and the exchange rate, the Government of Dominican Republic (GoDR) still controls some domestic prices and foreign exchange (forex) flows through import pricing and quota policies for agricultural products and energy products. Since 1999, GoDR raised the foreign exchange commission charged by the Central Bank on forex transactions from $1.75 \%$ to $5 \%$. GoDR has announced plans to eliminate the $5 \%$ forex commission, but has delayed doing so, while seeking alternative revenue generating sources. The $5 \%$ forex commission was, however, waived for traditional agricultural exports - coffee, cocoa sugar, tobacco - in August 2001. In September 2001 the forex commission was lowered from 5\% to 4.75\%, and in April 2002, commissions on insurance transactions were waived.

Misaligned exchange rates and high export taxes on traditional Dominican agricultural commodity exports, such as sugar, coffee and cocoa, which prevailed in the 1980s, have been blamed for placing these commodities at a relative comparative disadvantage in international markets (e.g., Varangis, 1989; World Bank, 1991; Schiff, 2001). They also placed these traditional agricultural exports at a comparative disadvantage relative to non-traditional (untaxed) agricultural export enterprises and crops destined for domestic markets. Direct export taxes for coffee and cocoa existed from 1975 to 1992. This taxation represented a significant transfer of

\footnotetext{
${ }^{2}$ This sub-section draws upon Central Bank publications from its website and The Economist's 2001 Country Profile for DR (The Economist, 2001).
} 
resources from coffee and cocoa producers to government coffers (Varangis, 1989). Additional taxes on exports were levied to fund public sector activities that were supposed to support the coffee and cocoa sectors. With exchange rates better aligned in recent years (Schiff, 2001), and the elimination of export taxes, the coffee and cocoa exports should, ceteris paribus ${ }^{3}$, be more profitable than previously.

It should be pointed out that in recent months there has been a rapid devaluation of the Dominican peso, largely as a result of severe problems in the financial sector (related to a scandal at the commercial bank Baninter). The Dominican peso was about DR \$17/US\$ in July 2002 and about RDS27/US\$ in the end of May 2003. This rapid devaluation (the Dominican Peso lost about $60 \%$ of its value relative to the US\$ from January to May 2003) is causing economic instability and increasing the rate of inflation.

\section{B. Population, Per Capita GDP and Poverty}

Economic restructuring and the emergence of tourism and light manufacturing industries have been associated with increased urbanization, changes in employment patterns and impacts on the distribution of economic gains. Some of these changes are described below.

\section{B.1 Population}

Population increased from 5.2 million in 1980 to 8.4 million in 1999 (see table I.4), while population growth rates fell from 2.2\% from 1980-1990 to 1.8\% per annum from 1990-1999. Over time, a major shift has taken place in urban-rural population compositions. The rural population has remained stable at about 3 million people, while urban populations almost doubled from 2.9 to 5.4 million from 1980 to 1999 . Consequently the share of rural population decreased from $49 \%$ in 1980 to $36 \%$ in 1999 . Most of this change is due to increased rural-urban migration and not to differences in fertility.

\begin{tabular}{|l|l|l|l|}
\hline \multicolumn{4}{|l|}{ Table I.4: Dominican Republic: Population and GDP per Capita 1970 - 1999 } \\
\hline & $\begin{array}{l}\text { Population } \\
\text { In Millions }\end{array}$ & $\begin{array}{l}\text { Per Capita GDP } \\
\text { RD\$ in Real Prices }\end{array}$ & $\begin{array}{l}\text { Per Capita GDP } \\
\text { US\$ Current Prices }\end{array}$ \\
\hline 1970 & 4.0 & 371 & 325 \\
\hline 1975 & 4.7 & 487 & 655 \\
\hline 1980 & 5.4 & 544 & 988 \\
\hline 1985 & 6.1 & 535 & 834 \\
\hline 1990 & 6.8 & 548 & 813 \\
\hline 1995 & 7.6 & 601 & 1597 \\
\hline 1999 & 8.4 & 740 & 2082 \\
\hline
\end{tabular}

Source: ECLAC (2001)

Population Data: US Census Bureau website.

\section{B.2 Per Capita GDP and Poverty}

From 1970 to 1999 per capita GDP in constant RD\$ doubled (see table I.4). Although some improvements in poverty and employment have occurred, persistent poverty, especially in rural areas, and high inequality have accompanied the high overall economic growth rates of the 1990s. For example, in 1998 , the wealthiest $20 \%$ of the population accounted for $47 \%$ of total income

\footnotetext{
${ }^{3}$ The term "ceteris paribus" is key, because other conditions have changed that affect the profitability of coffee and cocoa, notably international market prices.
} 
and the poorest $20 \%$ for only $7 \%$ of income (World Bank, 1999). The distributions of assets and other resources, particularly land, are also skewed.

Poverty in Dominican Republic is mostly a rural phenomenon (World Bank 2001). Rural poverty rates are about $40 \%$ compared to about $20 \%$ in urban areas, and about $60 \%$ of the poor are located in rural areas. A high proportion of rural poverty is concentrated in certain parts of the country, particularly in areas along the Haitian border. Rural poverty and agriculture are inexorably linked. While many farmers who specialize in agriculture are not poor, smaller scale farmers, those who live in less favored areas, and people dependent on agricultural wage labor are more likely to be counted among the rural poor (World Bank, 2001).

\section{Dualism in Dominican Agriculture}

Dominican agriculture is characterized by pronounced dualism. This dualism exists across and between specific sectors. For example, in 1992, 31\% of coffee producers were classified as low income and 15\% as high income (World Bank, 2001). At the same time, 14\% of cocoa producers were classified as low income and $8 \%$ as high income. There were (proportionally) about twice as many poor coffee producers as cocoa producers, but about twice as many high income coffee producers as cocoa producers. Thus, dualism appears more pronounced in coffee. Income and land distributions vary dramatically across other crops too. Dualism makes it difficult to make crop-specific generalizations about producers. The dualism results from wide differences in assets, access to technology, and access to markets.

Recent growth in exports and dynamic agriculture sectors may not have directly contributed to rural poverty reduction. Medium-scale and other farmers with high levels of human and physical assets have been the main beneficiaries of this growth, although the poor benefit indirectly through labor market linkages and lower food prices. Dualism in Dominican agriculture weakens the relationship between agricultural growth and poverty reduction, but certain forms of agricultural growth can clearly benefit the poor (World Bank, 2001).

The rural poor can also benefit from growth in other economic sectors. It is estimated that less than $30 \%$ of total rural income is directly generated from agricultural activities (Lopez, 2001). Another $15 \%$ originates in rural manufacturing and services, much of which are linked to agricultural activities. The remaining 55\% of rural incomes come from non-agricultural activities and non-employment sources such as government transfers and private remittances. As a result, a strategy intended to promote faster growth and poverty reduction in the rural sector should focus not only on promoting growth in agriculture sector, but also in other productive sectors (World Bank, 2001). As will be highlighted in this report, many coffee and cocoa producers receive significant shares of their incomes from other agricultural activities and non-agricultural activities. Thus, this message of the need for a broader rural economic approach than a more narrow agricultural or commodities approach is a key message.

\section{Overview of Factor Markets (Labor, Land, Finance)}

In this section we present an overview of factor markets, with a focus on the agricultural sector.

\section{C.1 Labor Markets and Human Capital}

Over the past few decades, the share of labor in agriculture has fallen, but the absolute number of persons employed in agriculture has remained relatively constant (table I.5). Important changes have recently occurred in rural labor markets in the Dominican Republic. Non-agricultural 
employment opportunities and rural-urban migration have contributed to a general tightening of rural labor markets and labor shortages for low-wage agricultural tasks are relatively new phenomena.

Table I. 5 Dominican Republic Economically Active Population Total \& Agriculture 1980-1999

\begin{tabular}{|l|l|l|l|l|l|}
\hline & $\begin{array}{l}1980 \\
\text { millions }\end{array}$ & $\begin{array}{l}1990 \\
\text { millions }\end{array}$ & $\begin{array}{l}1999 \\
\text { millions }\end{array}$ & $\begin{array}{l}\text { Growth Rate } \\
1980-1990 \%\end{array}$ & $\begin{array}{l}\text { Growth Rate } \\
1990-1999 \%\end{array}$ \\
\hline Total & 2.10 & 2.86 & 3.64 & 3.1 & 2.7 \\
\hline Agriculture & 0.682 & 0.711 & 0.634 & 0.4 & -1.3 \\
\hline $\begin{array}{l}\text { \% Share Employed } \\
\text { Agriculture }\end{array}$ & $32 \%$ & $25 \%$ & $17 \%$ & & \\
\hline \% Share GDP in Agriculture & $16 \%$ & $14 \%$ & $11 \%$ & & \\
\hline
\end{tabular}

Source: ECLAC (2001)

Seasonality of agricultural labor demand is particularly pronounced due to the rainfed nature of most Dominican agriculture and the inherent seasonality in production - most notably in traditional export commodities (like coffee and cocoa). This seasonality contributes to seasonal unemployment and migration of labor. In some regions, the coffee and cocoa harvesting seasons overlap and compliment work in other crops to provide continual employment of migrants who follow harvest cycles. Migrants are among the country's poorest workers, but agricultural laborers outside the migrant stream also tend to be poor. Seasonality of agricultural production and widespread small landholdings mean that most farmers seek additional sources of employment and income. This is the case for many coffee and cocoa producers.

Although difficult to measure, unemployment and under-employment are characteristic of many rural areas in the Dominican Republic. Traditional areas of agricultural production such as the Cibao Valley area in the north central part of the country (the valley is the traditional "breadbasket" of the Dominican Republic, and coffee and cocoa are produced on the mountains) tend to have a greater number of unemployed and seasonally unemployed workers than areas that more recently introduced intensive agricultural activity, such as the Nizao area in the south. In these intensive agricultural areas the boom in fruit and vegetable production has resulted in practically full employment of the farm labor force, and diversification together with widespread use of irrigation has reduced the seasonality of labor demand. According to a recent ECLAC (2001) study, because of alternative employment opportunities, there have been increasing shortages of inexpensive labor, particularly for coffee.

A major influence on labor markets and wages in the Dominican Republic is the existence of a relatively large amount of Haitian migrants, some residing legally and others illegally (Schiff, 2001). Most Haitians in the Dominican Republic are uneducated and have limited skills, and many work in construction and agricultural enterprises. In agriculture, most Haitians work as seasonal labor for the traditional export commodities. It has been reported that: "Many Dominican farm and other employers are complaining of labor shortages — an estimated $80 \%$ of Dominican Republic construction workers are Haitians, and they report earning $\$ 5$ to $\$ 8$ a day. Dominican coffee growers employ about 35,000 Haitians and 15,000 Dominicans to harvest coffee, and they complained of labor shortages because of the deportations. Haitians harvest an estimated $80 \%$ of Dominican coffee, ... and workers earn about $\$ 3$ for each 70 -pound box of coffee beans they pick." (Migration International, 2000)

The issue of Haitian migrants, their rights, and abuses of their rights has been contentious in the Dominican Republic. These issues exist and have important impacts on rural labor markets and 
wages. Government policies toward Haitian labor issues will have an impact on the future of the coffee and cocoa sectors; in particular with respect to farm sizes and technologies.

\section{Human Capital}

Since the Dominican Republic has tended to invest relatively little in social development, education levels and health indicators are among the lowest in the Latin America and Caribbean region (World Bank, 2001). Education levels in rural areas tend to be low, with about $25 \%$ of rural household heads having no schooling at all, and about $60 \%$ having 1-6 years of school. ${ }^{4}$ The lack of education and basic reading literacy is a constraint on improving agricultural productivity, particularly in sectors where global forces are creating increased competition, such as coffee and cocoa. In recent years, the main value of schooling in rural areas has been to facilitate migration to urban areas where returns to education are higher.

\section{C.2 Land Distribution and Land Titles}

The distribution of land in the Dominican Republic reflects the general dualism that characterizes the agricultural sector. Overall land distribution is highly skewed, and less than $50 \%$ of the rural population has access to formally titled land. ${ }^{5}$ About $40 \%$ of households with access to land own less than 1.2 ha and about $75 \%$ own less than 3.1 ha. In contrast, the largest 700 farmers $(0.3 \%$ of all farmers) control more than $15 \%$ of the agricultural land (much of these farms being extensive livestock operations). About $15-20 \%$ of total agricultural land is owned by government (SEA, Agricultural Census 1998).

As a result of historical factors, a high proportion of rural land is occupied without legal titles, and rural producers, do not possess clear rights to the land they occupy (de Ceara, 1986). In the last agricultural land registry, carried out in 1998, it is estimated that only $45 \%$ of the land is titled. An Agrarian Reform Program was launched in the 1960s, through establishment of the Instituto Agraria Dominicana (IAD), as a means to settle landless peasants on unused lands (de Ceara, 1986). The program has not had a major impact on the national land distribution situation (nor was it expected to do so), and some of these lands have not been legally titled.

The lack of legal land titles is a constraint to the expansion of commercial financial services into the agricultural sector. The inability to use land as collateral excludes those without land title from improved access to financial services, especially from commercial banks (Poyo, 2003). Lack of title leads to sub-optimal investment in the agricultural sector, lower productivity and growth, and contributes to the highly skewed income distribution in this sector (since wealthier large scale farmers often have title and access to formal and informal finance). On the other hand, as will be discussed, because they are perennial crops, some coffee and cocoa producers without formal title are able to use their plantations as a proxy for land ownership.

\section{C.3 Financial Sector ${ }^{6}$}

Following the severe banking crisis in the late 1980s and early 1990s and the tightening of prudential regulations on the part of the Monetary and Bank Supervisory Authorities, the Dominican Republic's banking system has become more risk adverse (World Bank, 2000; Fitch, 2002). This tightening follows years of poor supervision of banks, highly fluctuating interest rates and attempts by government to set ceilings on interest rates charged on loans, high levels of

\footnotetext{
${ }^{4}$ A World Bank "Early Childhood Education Project" began in 2002 to improve education achievements.

${ }^{5}$ About 200 families in the DR control about 600,000 ha , about 50\% of the arable land (Lopez, 2001).

${ }^{6}$ This section on the financial sector draws heavily on background papers prepared for the CRMG by

Domincan consultants Dr. Jeffrey Poyo (Poyo, 2003) and Teofilo Gomez (2002).
} 
loan defaults, etc. Historically, both public and private sector banks expected - and often received - bailouts from the government to re-capitalize, often at politically expedient moments.

The process of financial liberalization has led to rapid growth in the volume of financial services transacted in the domestic economy, and to consolidation of the number of institutions in the market. The reduction in the supply of subsidized agricultural credit from the second tier-lending window of the Central Bank has reduced the flow of agricultural credit. Commercial interest rates are high - about $25-30 \%$ per annum (before the current financial crisis) - which reduces the demand for agricultural credit (Schiff, 2001). Scarce agricultural credit makes the coffee and cocoa sectors less competitive compared to other countries with less expensive credit and better functioning banking systems. Because tree crops, like coffee and cocoa, have a long gestation period, they are especially sensitive to interest rates and credit access (Schiff, 2001).

Financial services for the agricultural sector in the Dominican Republic have historically been limited. Following financial sector reforms and Hurricane Georges, commercial banks have been withdrawing from the provision of agricultural credit. The main reasons given on the part of the private bankers for this are the excessive risks that accompany financing to the agricultural sector. The principal sources of risk perceived by the private banking institutions are: price risks, lack of appropriate loan guarantees (e.g., land titles), weather shocks, weak administration on the part of the farmers themselves, as well as the distortions in pricing generated by the marketing and financing functions of the GoDR (Poyo, 2003). In addition, rapid growth in construction, telecommunications, commerce, tourism and services over the past decade has provided the banking system with an attractive alternative to financing agricultural production (Schiff, 2001). ${ }^{7}$

Most private banking institutions do not offer financial services directly to smallholder producers (Schiff, 2001), but smallholders access credit though other sources. These producers depend on informal financial markets and exporters. The latter have access to credit from the domestic (and sometimes international) banking system. Historically, coffee and cocoa exporters and intermediaries have been a source of pre-harvest financing for producers. Thus, official data on lending to coffee and cocoa producers are under-reported, since these are "informal" financing arrangements. $^{8}$

Table I.6 Loan Portfolio of Principal Financial Institutions, 2000 (values in RD\$)

\begin{tabular}{|l|r|r|r|}
\hline Type of Institution & \multicolumn{2}{|l|}{$\begin{array}{l}\text { Total Loan } \\
\text { Portfolio }\end{array}$} & \multicolumn{2}{l|}{$\begin{array}{l}\text { Agriculture Loan } \\
\text { Portfolio }\end{array}$} & $\begin{array}{l}\text { Share } \\
\text { Agriculture }\end{array}$ \\
\hline Commercial Banks & 78,228 & 3,469 & $4.4 \%$ \\
\hline Development Banks (DEFINPRO) & 5,329 & 442 & $8.3 \%$ \\
\hline Banco Agricola & 2,440 & 2,494 & $100.0 \%$ \\
\hline Savings and Loan Associations & 18,280 & -- & -- \\
\hline Other & 2,493 & -- & -- \\
\hline Total & 104,330 & 6,405 & $6.2 \%$ \\
\hline
\end{tabular}

Source: World Bank (2002), based on Gomez (2002).

\footnotetext{
${ }^{7}$ Rapid economic growth has created a growing middle class and opened greater opportunities for expansion in consumer and small enterprise credit. The deepening of the consumer credit markets and small enterprise lending enables the banking system to rapidly expand its loan portfolios while shrinking participation of the agricultural sector in loan portfolios. The banking system has moved towards shortterm commercial lending (Poyo, 2003).

${ }^{8}$ Schiff (2001, p.63) notes: "Processor (mills) or exporters may lend to farmers since they exercise control over their output ... the lack of access to formal credit leads to interlinkages between the production and credit markets. The same is true for coffee, cocoa and tobacco where financing comes from exporters. Thus taxpayer money is used to subsidize credit, which reaches the larger farmers, mills and exporters, but does not reach the most needy."
} 
Financial institutions serving the Dominican agricultural sector are described next:

Banco Agricola. The state owned Agricultural Development Bank (Banco Agrícola - BA) is a major lender to the agricultural sector, and its loans are subsidized by GoDR. The supply of agricultural credit from BA has been unstable. Lax credit policies and tolerance of loan delinquency have served to undermine the credit discipline on the part of BA's borrowers, and contribute to the perception on the part of banking institutions that the credit risks associated with the agricultural sector are greater than they might be in reality. ${ }^{9}$ BA directs a large share of its lending operations for rice production to support the Government's agricultural sector policies for Agrarian Reform and protection of import substituting food staples. ${ }^{10}$ Although the concentration of BA's loans for rice production has declined recently declined, it still receives between $40 \%$ and $50 \%$ of annual disbursements.

DEFINPRO. Subsidized longer-term credit is available to the agricultural sector through the Department for Development and Financing of Projects ("Departamento de Desarrollo y Financiamiento de Proyectos" - DEFINPRO, of the Central Bank). The interest rate has been fixed at $13.5 \%$ (about one-half of commercial rates) and conditions for grace period and repayment are flexible. The grace period can vary between 6 months for working capital to 5 years for investment loans while the period of repayment can range from 2 years in the case of credit for working capital up to 12 years for investment loans (EDE, 2000). Usually, credit packages are tailored to meet the specific conditions of projects. Disbursements are made through BA and commercial banks such as Banco de Reservas, Baninter or Banco Popular. This credit is highly subsidized, in limited supply, and mostly goes for irrigation and non-traditional horticultural crops or livestock enterprises. The well-known effects of credit rationing for subsidized credit that favour larger farmers is also the case in Dominican Republic.

Producer Associations and Cooperatives. Producer associations and cooperatives serve as a financial intermediaries between banks (or exporters) and producers. They receive funds from international agencies and NGOs and on-lend to members. GoDR has long promoted producer associations and cooperatives for the coffee and cocoa sectors, with limited success (World Bank, 1981; 1991). While in many other developing countries producer associations and cooperatives have served as an effective institutional vehicle to overcome the relatively high transactions costs faced by commercial banks, in the Dominican Republic most of these institutions have been financially fragile and suffered from weak governance. In turn, since these groups are relatively weak and producers lack the titles to use their land as collateral, they cannot provide the guarantees that commercial banking institutions require. As a result, GoDR and the donor community have used producer cooperatives as vehicles for lending (Schiff, 2001). Reliance on these fragile institutions has made cooperatives vulnerable to financial collapse because of the lack of tangible collateral. ${ }^{11}$ To break this vicious cycle, some attempts are being made to help producer associations and cooperatives is to obtain legal title to members' land (see EDE Consulting, 2002).

Microfinance Institutions (MFI). Over the last 10 years a small group of rural credit unions affiliated to the Asociación de Institutiones Rurales de Ahorro y Crédito (AIRAC) has grown rapidly, and improved their efficiency and profitability. These institutions have funded their

\footnotetext{
${ }^{9}$ There have been historical incentives not to repay loans, agricultural lending appears risky. With appropriate incentives for financial discipline, loan repayment rates might be higher.

${ }^{10}$ Most notably for rice price supports, and investments in irrigation for rice production.

${ }^{11}$ Some producer associations and cooperatives receive subsidized credit and/or grants from donors and NGOs, which cause well-known disincentives for loan repayment.
} 
growth through the mobilization of rural savings. They have achieved growth rural areas because their institutional culture is more compatible with small entrepreneurs and agricultural producers. Although their ownership structure might be conducive for expanded lending to smallholder producers, it is well known that this same mutual based ownership structures can suffer from governance problems that tend to undermine the effectiveness of credit risk management. ${ }^{12}$ To date, there has been minimal direct lending by MFIs for agricultural enterprises. However, since loans are fungible, it is difficult to assess the extent loans are being used for agriculture.

Crop Insurance. The Dominican Republic is exposed to weather risks, and some areas are particularly vulnerable to hurricanes and other tropical storms. Coffee and cocoa growing areas are particularly vulnerable to hurricane damage. However, no formal natural disaster insurance exists in the Dominican Republic. Nor is there crop insurance against other weather related risks such as droughts and floods, or against yield losses due to diseases and pests. Since mid-2001, there has been an attempt by Banco Agricola (the public sector agricultural development bank) to begin a crop insurance scheme for rice producers (a large part of BA's clientele) through a subsidiary called Aseguradora Agropecuria Dominicana, S.A. (AGRODOSA). AGRODOSA is receiving technical assistance from Partner Re, an international re-insurance company. Premiums for rice producers (many of whom use irrigation) are about $7 \%$ of value insured, and are being subsidized at about 50\%.(producers pay 3.5\%). AGRODOSA is interested in developing new insurance products and services for the agricultural and rural sectors - especially linked to credit.

Commodity Exchange. The Junta Agroempresarial Dominica (JAD), an umbrella group formed to promote the interests of the agricultural sector (representing producers, exporters, importers, processors, financiers, academics, and policy makers from the public and private sectors) set up a commodity exchange called Bolsa Agroempresarial de la Republica Dominicana (BOLSAGRO) in 2000 (with assistance from IADB, IICA, and the Chicago Commodity Exchange). For example, there is a "Coffee Committee" in JAD. To date, BOLSAGRO is providing services that assist in the "commercialization" of agricultural and livestock produce, such as: information about prices and markets, and acting as a meeting place and clearinghouse for commodities, horticultural products, and livestock products and inputs. And it assists members in obtaining information on accessing international commodity market exchanges (e.g., in New York, Chicago, London) and international financial services. However, it is not conducting business as a commodity market exchange. Over time, the types of marketing and financial services to improve risk management and lower production and marketing costs are expected to expand, as BOLSAGRO offers market-based instruments as an alternative to price-setting practices associated with the Institute for Price Stabilization (INESPRE), which are slowly being phased out (JAD, 2002a;b).

\section{Recent Agricultural Sector Performance and Policies}

Dualism is a major feature of Dominican agriculture. The more traditional smallholder sector is associated with small landholding sizes, diversified on-farm production of staple and marketed crops, low-productivity livestock production, diversified income bases including varied off-farm

\footnotetext{
${ }^{12}$ In the new Monetary and Financial Law, passed in November 2002, rural credit unions should be incorporated into the regulatory and supervisory framework established for all financial intermediaries that mobilize domestic deposits. Their incorporation should improve their efficiency, financial transparency and further support their competitive advantage within rural and agricultural markets. Credit unions must confront many of the same structural difficulties which impede the flow of credit from private banking institutions.
} 
sources, stagnant productivity growth and pervasive poverty. The modern agricultural sector is increasingly dynamic, and is characterized by larger landholding sizes located in the more fertile agricultural areas, specialized monoculture production, high levels of fixed and variable inputs, and a focus on horticultural crops for exports and domestic markets, and modern livestock production (especially dairy and poultry). Recently, dualism has emerged even within specific crop sectors. For example, the coffee and cocoa sectors are gradually dividing into a modern sector with high technology production systems and increased consolidation of landholding sizes, while the traditional sector experiences low productivity and shrinking market shares. This dualism across agriculture and within specific sectors has major implications for a broad-based agriculture-led poverty reduction strategy. That is, it is not really possible to have a "one-sizefits-all" strategy even for individual commodities, such as coffee and cocoa; because of the vast differences between producers. Alternatively, a "one-size-fits-all" strategy could ostensibly favor or harm one of the extremes on the dualism spectrum; thereby exacerbating the dualism.

\section{D.1 Overview of Recent Performance of the Agriculture Sector}

Growth in agriculture has not been as fast as other sectors of the economy since 1990 . Aggregate growth figures mask major shifts within the agricultural sector, as agricultural dualism manifests itself through a restructuring in the sector. A major shift has occurred between the importance of crops relative to livestock (see table I.7). Between 1970 and 1999, the value of crop production increased by $45 \%$, while the value of livestock increased by $222 \%$. Part of this shift was caused by the evolution of the economy: as urban incomes grew, demands for dairy and poultry products increased. Another part was due to policy biases that tended to favor some crops and livestock and/or discriminate against the traditional exports such as coffee, sugar and cocoa. These policy biases are discussed in more detail below.

A second shift occurred between the importance of traditional crops relative to non-traditional crops. Production and value of non-traditional crops grew significantly in recent years. These changes are the result of market forces such as growing demands for non-traditional goods, deteriorating terms-of-trade and changing comparative advantages, and policy changes. Policy changes include lower sugar quotas in the US, reduction of direct and indirect export taxes for traditional export commodities, and preferential government assistance for import substitutes. Dynamic "new" sectors such as horticultural crops and citrus received credit and other input subsidies, technical assistance and extension services, import quotas and tariff protection, and in some cases price supports. Production of traditional crops has stagnated or declined as resources moved to more dynamic sectors. For example, coffee and cocoa together accounted for about $13 \%$ of the value of total Dominican exports in 1996 and less than 5\% in 2000; at a value of about US\$ 50 million.

Currently there are about 40,000-50,000 coffee and 40,000-50,000 cocoa producers, about 35$40 \%$ of all Dominican farmers. In addition, an estimated 80,000-100,000 laborers work in coffee and $\operatorname{cocoa}^{13}$, and thousands of others work in linked economic activities such processing, marketing, transport, and other services. Thus, a large proportion of Dominican households still derive at least some of their income from coffee and cocoa production. The key here is the phrase "at least some of their income". More research is needed to quantify the economic linkages of the coffee and cocoa sectors, and the relative income shares from these commodities for different types of households.

${ }^{13}$ As mentioned previously, because some small coffee and cocoa producers are also hire laborers for larger producers, and the large amount of Haitian labor, there are no accurate "official" figures. 
Table I.7: Dominican Republic Total GDP of which Agriculture, Crops, Livestock 1970-1999 (in constant 1970 RD\$ prices)

\begin{tabular}{|l|l|l|l|}
\hline \multirow{2}{*}{ Year } & Total Agriculture & Crops & Livestock \\
\cline { 2 - 4 } & $\begin{array}{l}\text { \% Share } \\
\text { GDP }\end{array}$ & $\begin{array}{l}\text { \% Share } \\
\text { GDP }\end{array}$ & $\%$ Share GDP \\
\hline 1970 & $23 \%$ & $16 \%$ & $7 \%$ \\
\hline 1975 & $17 \%$ & $11 \%$ & $6 \%$ \\
\hline 1980 & $16 \%$ & $10 \%$ & $6 \%$ \\
\hline 1985 & $16 \%$ & $10 \%$ & $6 \%$ \\
\hline 1990 & $13 \%$ & $7 \%$ & $6 \%$ \\
\hline 1999 & $11 \%$ & $5.5 \%$ & $5.5 \%$ \\
\hline
\end{tabular}

Note: Percentages are rounded off. Total Agriculture also includes fisheries and forestry. Source: ECLAC (2001).

In addition to the domestic policy biases against traditional export commodities, these commodities have faced unfavorable international prices in recent years. Downward price trends have exacerbated the underlying structural deficiencies that had prevailed, but had often been concealed by periodic price spikes and periodic Government bailouts in response to emergency situations. According to ECLAC (2001, p.86): "In the sugar industry, financial difficulties [have] continued to be a problem, as did worn-out machinery and equipment, and in the coffee industry, the assistance could not make up for the low yields resulting from the failure to maintain the plantation and the shortage of labor, especially foreign labor."

Increasing market and trade liberalization and the phasing out of the National Institute for Price Stabilization has worsened the balance of agricultural trade for Dominican Republic (table I.8). ${ }^{14}$ This change is largely a function of declining international prices and quantities exported for traditional export commodities and increases in imports of grains and oilseeds (much of it for livestock and poultry feed).

Table I.8: Trade Balance of Agricultural Products 1980-1999 (in US\$ millions)

\begin{tabular}{|l|l|l|l|l|l|l|l|}
\hline 1980 & 1985 & 1990 & 1995 & 1996 & 1997 & 1998 & 1999 \\
\hline 311 & 307 & 50 & -147 & -108 & -129 & -188 & -379 \\
\hline
\end{tabular}

Source: ECLAC (2001)

\section{D.2 Recent Agricultural Policies}

Like many Latin American and Caribbean countries, agricultural policy in the Dominican Republic was fundamentally restructured during the 1980s and 1990s (Raynolds, 2002). Traditional policy biases against exports have been lowered or removed, direct subsidies have become more infrequent, and the public role in agriculture has been altered. These changes represent significant policy shifts.

Historically, the GoDR heavily taxed its export agriculture sectors as a means of raising revenues. Beginning in the 1990s, export tariffs began to fall, but biases in favor of import-substituting

\footnotetext{
${ }^{14}$ Also, as a result of this liberalization, exposure to international price and market prices risks has increased for farmers. Increased price variability and declining international prices for agricultural commodities is having a negative impact on some of the rural poor (World Bank, 2001). As a result, it might be worthwhile considering direct income support programs to mitigate negative impacts of trade and agricultural reforms on small farmers, like the widely acclaimed PROGRESA program in Mexico.
} 
crops kept the traditional export sectors at a relative disadvantage. These distortionary policies took the form of financial subsidies, import tariff support and others. For example, the average producer subsidy from $1990-1998$ was about $23 \%$ per unit price of rice, $57 \%$ for maize and $66 \%$ for chicken, while there was a negative subsidy (or tax) of $35 \%$ on coffee and $30 \%$ on sugar cane (see table I.9). ${ }^{15}$

Table I.9 Dominican Republic Producer Subsidy Equivalents 1990-1998

\begin{tabular}{|l|l|l|l|l|}
\hline & $\begin{array}{l}\text { Avg. \% Subsidy } \\
1990-93\end{array}$ & $\begin{array}{l}\text { Avg. \% Subsidy } \\
1994-96\end{array}$ & $\begin{array}{l}\text { Avg. \% Subsidy } \\
1996-98\end{array}$ & $\begin{array}{l}\text { Avg. \% Subsidy } \\
1990-98\end{array}$ \\
\hline Import Substitutes & & & & \\
\hline - Rice & 16.0 & 28.2 & 30.2 & 22.8 \\
\hline - Maize & 73.7 & 43.4 & 40.9 & 56.9 \\
\hline - Garlic & 47.8 & 25.2 & 24.7 & 35.2 \\
\hline - Onion & 37.9 & 40.9 & 39.3 & 39.5 \\
\hline - Chicken & 63.8 & 67.7 & 66.1 & 66.0 \\
\hline Export Crops & & & & -34.9 \\
\hline - Coffee & -25.3 & -43.0 & -30.7 & -30.0 \\
\hline - Sugar Cane & -23.9 & -34.9 & -34.9 & \\
\hline
\end{tabular}

Source: IADB (2001).

Thus, despite removal of export tariffs, implicit biases against the traditional sectors have persisted. We use the term "implicit biases" to emphasize the fact that non-traditional agricultural sectors have been receiving various forms of support from the public sector. It is not known the degree to which such biases led to reallocation of resources away from the traditional export sectors, but data on productivity growth in coffee and cocoa (shown below) show that they did not keep pace with competing countries. ${ }^{16}$ However, it is important to highlight the fact that public and other resources have gone to the coffee and cocoa sectors during the 1990s. These resources came in the form of support from international development agencies and NGOs to the respective sectors. Most of these funds came in response to natural crises, such as weather and pests, or to adverse market conditions. This support came with the approval of government, and offset and compensated (to some extent) for the institutional biases noted above. What is not known is the full extent of the direct benefits received by producers through these different initiatives. While what is known is that much of the support to the coffee and cocoa sectors has been ad-hoc and not administered with a clear vision as to how they might impact the sectors and different types of producers - and to what extent they complement other government policies and objectives.

In contrast to historical policy biases that "taxed" exports of coffee and cocoa, government has traditionally protected domestic processors targeting the local market. For example, tariffs on imports of coffee beans are $14 \%$ and for ground coffee $20 \%$. Cocoa beans and butter and cocoa powder and chocolate face similar import tariffs. An additional $12 \%$ value added tax on imports further protects domestic coffee and cocoa processors from foreign competition. A detailed analysis of these import policies and the impacts on domestic and export coffee and cocoa markets and prices is recommended; especially considering the high degree of concentration of marketing structures in these sectors.

\footnotetext{
${ }^{15}$ For details on producer subsidies and evidence that the support for import substitutes and bias against traditional exports existed previously in DR, see Valdes, Schaeffer and de los Santos (1995).

${ }^{16}$ On the other hand, as pointed out in this report, comparing data on average yields as a proxy for productivity are rife with inaccuracies, especially in a country like DR with its periodic hurricanes that cause large scale damage to coffee and cocoa plantations.
} 


\section{Examples of Recent Emergency Assistance to the Coffee and Cocoa Sectors}

Coffee Sector: International coffee prices in 2000 were about one-half of what they were in 1997, and have continued to fall. In response to lobbying from the coffee industry, in 2001 GoDR decided to provide exporters with a RD $\$ 200$ for every hundredweight (i.e., qq) exported. This amounts to a subsidy of about $\$ 260 / \mathrm{MT}$ in July 2002 prices when international coffee prices were about \$1200/MT. Government established a special fund of RD \$140 million for this purpose. Exporters, in turn, are supposed to pass this subsidy on to coffee producers. Because coffee producers are used to receiving a percent share of the international coffee price, and the program was highly publicized, it is believed that most producers were able to actually receive (all or part of it from coffee purchasing intermediaries) this subsidy from GoDR in the form of a "price premium" irregardless if the coffee was actually destined for export. This "emergency program" is indefinite in duration and will only be suspended when world prices exceed $\$ 100$ per hundredweight.

Cocoa Sector: Cocoa producers were severely affected by Hurricane Georges, which struck at a critical moment in the marketing cycle. Cocoa production and exports had peaked in 1997/8, and exporters had advanced significant pre-harvest loans in anticipation of a larger 1998/9 harvest. The hurricane caused serious damage to cocoa plantations (with some Dominicans calling it the "Cocoa Hurricane"), reducing production by more than one-half. Many producers were neither able to deliver cocoa to exporters nor to repay loans. In turn, exporters were not able to deliver on forward marketing contracts nor to repay their loans. This caused a major financial crisis in the cocoa sector, affecting exporters and producers alike. In response, the government established an emergency credit fund of RD $\$ 425$ million which was provided to the principal exporters and through Banco de Reservas. The objective of the program was twofold: a) to provide liquidity to exporters and, $b$ ) to provide cocoa producers with funding for the upcoming harvest and to maintain their income flows. Cocoa producers who did not have outstanding debt with the exporters were provided with a cash advance proportional to their past sales. Debt recovery (to Government) was funded through a tax on all exports of cocoa of RD\$100 per hundredweight. This emergency credit program was designed to inject liquidity into the cocoa sector at a time when it had been significantly decapitalized by the hurricane. Since cocoa prices have recently rebounded, the tax burden on the individual cocoa producers has become relatively minimal.

\section{D.3 Public Institutions}

The Secretariat of State for Agriculture (SEA) is the principal organization dealing with the agricultural sector. During the 1990s, SEA underwent major restructuring, and additional institutional restructuring is currently being undertaken. These efforts are designed to better prepare the SEA for an appropriate role in an era of market and trade liberalization. There is recent recognition that the Dominican Republic's agricultural growth strategy needs to be designed in the context of a broader pro-poor rural development strategy. The new IADB project called "Support for the Transition to Competitive Agriculture" reflects the new strategies and priorities for the agricultural sector (IADB, 2001). ${ }^{17}$ The World Bank is currently working with SEA to prepare an Agricultural Sector Strategy, during which priorities, policies and strategies will be reassessed.

\footnotetext{
${ }^{17}$ The objective of this $\$ 34$ million project is to enhance the efficiency of Dominican agriculture in order to make the agri-food sector more competitive and reduce poverty in rural areas. Major components are: a) support for the adoption of technology, b) food health and safety, and c) technical assistance for commercial and institutional reform. See the IADB website iadb.org for details.
} 
As part of the restructuring of SEA its relationship with the coffee and cocoa sectors has evolved. Formerly, the Coffee and Cocoa Departments were responsible for policy formulation and delivery of public services to the respective sectors. In 1976, GoDR set up Coffee and Cocoa Commissions. These had representatives from the public and private sectors and were created to assist SEA in policy formulation and were charged with carrying out some former functions of the Coffee and Cocoa Departments. More recently, as a part of an ongoing process of decentralization, a Coffee Council (CODOCAFE) was formed. CODOCAFE includes public and private sector representatives on its Governing Council. It is responsible for all functions of the Coffee Department and the Coffee Commission. A similar Council is planned for the cocoa sector (the law to create a Cocoa Council is pending in the Dominican Senate). These Councils were granted more autonomous status and are administratively independent of SEA. However, they are still largely financed by GoDR. They have legal status that allows more flexibility in contracting, and that allows for continued support of the sectors while complying with WTO freetrade agreements. This autonomous administration and flexibility, along with closer relations to the sector's stakeholders, are expected to provide an institutional framework for more efficient delivery of services and more objective and effective policy formulation.

Another important change in the of support for the coffee and cocoa sectors has been the transfer of research duties to the Instituto Dominicano de Investigacion Agropecuria y Forestal (IDIAF), which is also administratively autonomous and dependent on funding from GoDR. This should provide for a more professional and multi-dimensional approach to research, that encompasses agronomic issues, but also incorporates economic, social and environmental aspects of the coffee and cocoa sectors. IDIAF is working closely with CODOCAFE, and the cocoa sector.

\section{D.4. International Agencies and NGOs}

From 1982 to 1989, a World Bank-funded Cocoa and Coffee Project helped support both sectors (World Bank, 1981; 1991). See the Annex for a review of the projects' objectives and performance. The project involved a \$28 million loan of which \$24 was actually disbursed. Following hurricane damage in 1979, the project focused on rehabilitation and replanting cocoa and coffee farms, improvements in productivity and post-harvest practices to improve quality. During this project, the Presidency initiated a parallel program to support the coffee sector, which included subsidies to small-scale (less than 6.2 hectares) producers renovating and replacing tipica trees with higher-producing caturra varieties.

In addition to emergency assistance from GoDR to the coffee and cocoa sectors, significant assistance was provided by various international agencies following the devastation caused by Hurricane Georges. Thousands of hectares of coffee and cocoa plantations were rehabilitated and replanted with funding from the World Bank ${ }^{18}$ and IADB and other development agencies (e.g., USAID, GTZ, EU) and NGOs. Furthermore there has been a long history of direct support to the coffee and cocoa sectors from international agencies and NGOs, particularly aimed at small producers. This support has been justified by the perceived important social and environmental aspects of coffee and cocoa sectors, and potential impacts on poverty reduction. Major issues include the fact that the majority of coffee and cocoa producers are small landholders, many of whom are poor or near-poor, the high seasonal demands for unskilled labor (especially Haitian migrants), and environmental externalities related to coffee and cocoa production, which is mostly located in areas of sensitive watersheds.

\footnotetext{
${ }^{18}$ Part of the World Bank's Hurricane Georges' $\$ 114$ project was targeted to coffee and cocoa producers (World Bank, 1998).
} 
The major point to be made here is that GoDR has professed a somewhat "hands-off" approach to the coffee and cocoa sectors, by limiting direct taxation and financial support, and by establishing quasi-independent administrative institutions. Rather than formulating a strategic vision for the coffee and cocoa sectors, and providing transparent and direct support ${ }^{19}$, GoDR (often with assistance from international development agencies and NGOs) has continued to respond to the needs of these sectors in time of crisis. Examples include providing funds for post-Hurricane Georges recovery efforts, and assisting the cocoa sector to recover from the post-hurricane financial crisis. More recently, GoDR has provided assistance to the coffee sector to help deal with a sharp decline in international coffee prices (as detailed in the previous box). A more strategic and direct approach to the coffee and cocoa sectors would hopefully allow for a more efficient and equitable allocation of government, donor and NGO resources. This will require both improved discipline and improved coordination among all stakeholders in the sectors.

\section{E. Agriculture and the Environment}

Activities in the agricultural sector in the Dominican Republic affect environmental quality in rural areas in a number of ways. These impacts also spill over to urban areas and are frequently used to justify support for environmentally related services associated with agricultural production. Agricultural production activities (including the choice of technology and cultivation practices) are related to rates of deforestation, soil erosion and watershed degradation.

Perennials, such as coffee and cocoa, store carbon while reducing runoff and enhancing water quality.

The Dominican Republic is heavily dependent on hydroelectric power with 17 hydro-power plants and an estimated total capacity of $400 \mathrm{MW}$. Some valleys and plains depend on irrigation systems fed by the reservoirs of hydropower plants. More than one million hectares are irrigated stored in six hydroelectric dams. Also, several cities use water from the reservoirs as their primary source of drinking water. The reservoirs producing this power and providing water for irrigation and households are vulnerable to siltation due to upstream erosion. The major coffee and cocoa producing areas are strategically located in the major watersheds of the Dominican Republic, and the forest cover associated with coffee and cocoa production plays an important role in preventing soil erosion and maintaining the sustainability of the national hydroelectric system. Coffee plantations are particularly strategically located and important in the prevention of soil erosion.

As discussed later in the report, different cultivation and post-harvest practices in the coffee and cocoa sectors have positive and negative impacts on the environment. The GoDR recognizes the important interface between agriculture and the environment, and it is an issue that will be dealt with in the Environmental Sector Strategy currently being devised by GoDR and the World Bank (World Bank, 2003). In addition, CATIE has proposed some research on assessing environmental impacts of coffee, to be undertaken with IDIAF and CODOCAFE (CATIE, 2002). Also, USAID has been assisting CODOCAFE to generate a geographic information system for the coffee sector that could help in mapping producing areas and sensitive environmental zones (CODOCAFE, 2003). Better quantification of the environmental impacts of the coffee and cocoa sectors in Dominican Republic should be a priority. This data would allow for improved quantification of the environmental benefits and costs associated with these sectors; which could be used in the design of policies aimed at providing incentives or disincentives for certain types of land use and activities.

\footnotetext{
${ }^{19}$ Although GoDR has tended to provide some direct annual budgetary support.
} 


\section{Recent World Trends in Coffee and Cocoa Prices, Production, and Exports}

International coffee and cocoa markets have been characterized by extreme volatility over the past few years. Price volatility is associated with income risks for individual farmers and affects the risk-adjusted returns in the sectors. This section presents an overview of recent trends in world markets. Both sectors are experiencing a "crisis", although there are significant differences in their respective causes and the extent to which structural or temporary changes are occurring.

\section{A. Recent Coffee Prices, Production and Exports ${ }^{20}$}

During 2000 and 2001, worldwide oversupply caused coffee prices to drop to their lowest levels in 30 years, between US\$ 50-55 per hundredweight (about US\$ 2250-2500/MT), representing a hundred-year inflation-adjusted low. Coffee prices have fallen below the cost of production for many producers, causing economic and social hardships. The international "coffee crisis," has had particularly strong negative impacts on Central American and Caribbean countries, ${ }^{21}$ who primarily produce Arabica coffee. ${ }^{22}$ These problems were highlighted at a joint IADB-World Bank-USAID workshop held in early April 2002 in Antigua, Guatemala. Representatives of the Dominican Republic coffee sector attended this workshop ${ }^{23}$.

Coffee prices fluctuate dramatically between years (see Figure II.1). Coffee prices were high in the mid 1990s, and created optimism among producers and governments. This optimism resulted in expanded plantings and productivity-enhancing investments. Since reaching a relative peak in 1997 there has been a steady price decline as production and exports expanded. Short-term price projections are not encouraging (FAO, 2003, ICO, 2003). With demand growing relatively slowly and global production at high levels and expanding, most analysts predict that any coffee price recovery is likely to be slow. This situation threatens the longer-term profitability and sustainability of coffee production in Central America and the Caribbean.

The decline in international coffee prices has been affected by structural changes in supply and demand, and changes in issues related to coffee quality and niche markets. Since 1995, the world coffee market has experienced a steady increase in world production and export levels - notably increases in production of Robusta coffees by Brazil and Viet Nam. Thus, the current crisis in prices does not appear to be a cyclical phenomenon, but a direct consequence of the new structure of the market. Apart from over-supply, there have also been structural changes in demand (Ponte, 2002).

The major structural changes in the demand for coffee include: a) aggregate demand in the major importing countries is increasing a slow rate (especially relative to increases in supply), b) roasters are increasingly able to increase the absorption of lower quality Robusta coffees by

\footnotetext{
${ }^{20}$ This section is drawn mostly from the recent World Bank publication: "Dealing with the Coffee Crisis in Central America: Impacts and Strategies” (Varangis, Siegel, Giovannuci, Lewin, 2003).

${ }^{21}$ A recent report by Economic Comisión for Latin American Countries called: Centroamerica: El impacto de la caida de los precios del café highlights the extent of the crisis. (ECLAC, 2002).

${ }^{22}$ Arabica and Robusta are types of coffee beans, the former being grown mostly in Central and South America and the latter in Africa, Asia, and Brazil. Arabica is considered a higher quality coffee.

${ }^{23}$ Workshop proceedings can be found at: www. iadb.org/regions/re2/coffeeworkshop/
} 
processes such as steaming to remove the harshness of taste, and have become more flexible in switching between coffee types, and c) a small but viable segment of the market has emerged that focuses on quality and product differentiation (e.g., specialty and gourmet coffees, and "issue coffees" such as Fair Trade and environmentally friendly coffees).

Figure II.1: Coffee Price from 1967 to 2002 (prices in nominal US\$ per qq)

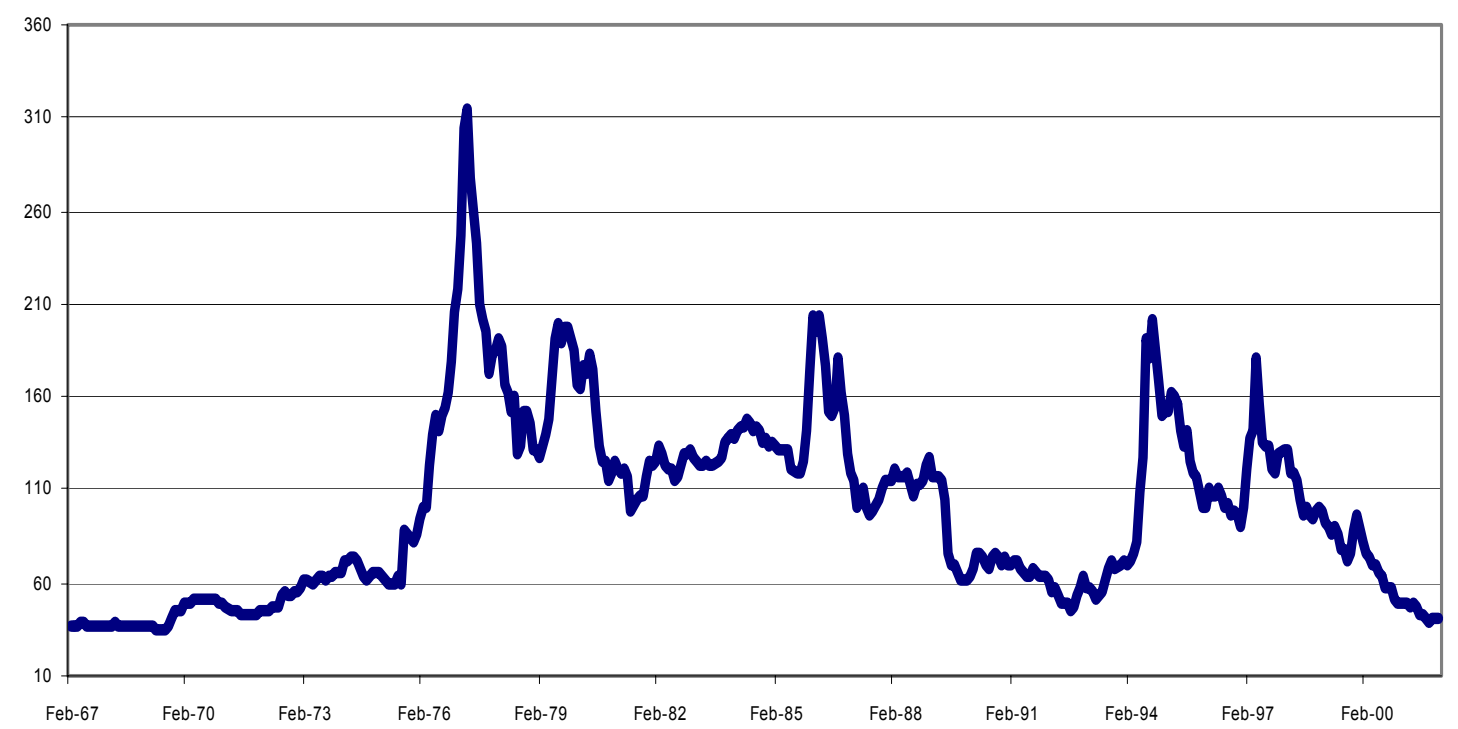

At the same time that supply of coffee has expanded there are growing consumer markets for gourmet and other specialty coffees (gourmet, fair-trade, organic, eco-friendly, etc.) that command a significant price premium (Fleischer, 2002). Central American and Caribbean countries are important players in these markets, and these niche markets are growing at a faster rate than more traditional markets. However, in the aggregate, these special coffee markets only represent a small share of global exports. Competition for these markets is increasing over time, as improving coffee quality and increasing access to these markets has become a major strategic direction of coffee programs for Central American and Caribbean countries (e.g., the new USAID "Coffee Initiative" that provides funding for all of Central American countries and the Dominican Republic). For more details on the global coffee situation, with a focus on Central America, refer to the report by Varangis, Siegel, Giovannuci, Lewin (2003), and recent coffee sector studies in Mexico (World Bank, 2002b) and Columbia (World Bank, 2002c).

\section{The Dominican Republic's Position in World Coffee Markets}

The Dominican Republic is considered a "minor player" in world coffee markets, in terms of its share of total world production and exports, which ranged between $0.4 \%$ to $1 \%$ from 1997 to 2002. The Dominican Republic also has a small share of global production relative to Central American countries (e.g, Costa Rica, Guatemala, Honduras) and is comparable to Nicaragua. 
Table II.1 Estimated Shares of Global Coffee Production of Selected Countries

\begin{tabular}{|l|l|l|l|l|l|l|}
\hline & 1997 & 1998 & 1999 & 2000 & 2001 & 2002 \\
\hline $\begin{array}{l}\text { Total Production } \\
\text { '000 bags }\end{array}$ & 96,213 & 106,055 & 114,418 & 112,404 & 111,282 & 117,689 \\
\hline Brazil & $23.6 \%$ & $32.6 \%$ & $28.3 \%$ & $28.6 \%$ & 30.9 & $40.1 \%$ \\
\hline Columbia & $12.7 \%$ & $10.4 \%$ & $8.3 \%$ & $9.4 \%$ & $10.8 \%$ & $9.6 \%$ \\
\hline VietNam & $7.2 \%$ & $7.0 \%$ & $10.2 \%$ & $13.2 \%$ & $11.7 \%$ & $7.6 \%$ \\
\hline Indonesia & $8.1 \%$ & $8.0 \%$ & $4.7 \%$ & $6.0 \%$ & $6.9 \%$ & $5.0 \%$ \\
\hline México & $5.0 \%$ & $4.8 \%$ & $5.4 \%$ & $4.3 \%$ & $3.8 \%$ & $3.4 \%$ \\
\hline Guatemala & $4.4 \%$ & $4.6 \%$ & $4.4 \%$ & $4.4 \%$ & $3.3 \%$ & $2.7 \%$ \\
\hline Costa Rica & $2.6 \%$ & $2.3 \%$ & $2.1 \%$ & $2.0 \%$ & $2.0 \%$ & $1.8 \%$ \\
\hline Honduras & $2.7 \%$ & $2.1 \%$ & $2.6 \%$ & $2.4 \%$ & $4.5 \%$ & $4.0 \%$ \\
\hline Nicaragua & $1.1 \%$ & $1.0 \%$ & $1.3 \%$ & $1.4 \%$ & $1.0 \%$ & $0.7 \%$ \\
\hline Domincan Republic & $\mathbf{1 . 0 \%}$ & $\mathbf{0 . 4 \%}$ & $\mathbf{0 . 6 \%}$ & $\mathbf{0 . 4 \%}$ & $\mathbf{0 . 4 \%}$ & $\mathbf{0 . 6 \%}$ \\
\hline
\end{tabular}

Source: ICO website.

Note : This is only a list of « selected countries.

To demonstrate the ever changing conditions in international coffee markets, here is an excerpt from a market update report on the international coffee situation in February 2003:

The March contract for coffee rose 1.35 cents to 65.30 cents a pound (US\$65.30/qq), as traders focused on a smaller Central American crop and estimates that Brazil's 2003-04 crop, to be harvested June through August, will be at least a third smaller than the last giant crop of 51.7 million 60-kilogram (132-pound) bags. The ICO said that combined 2002-03 output in Mexico and Central America will be down $21 \%-24 \%$ on the year. Vietnam's 2002-03 crop is at least $25 \%$ smaller, and Indonesia's is off 24\%. Brazilian coffee from the huge 2002-03 crop is ample, but of mostly lesser quality. Quality beans needed by roasters in North America and Europe for blends and to meet upscale demand are already in short supply. Because of crop problems in Guatemala, Costa Rica and Ethiopia, specialty-coffee roasters are seeking out quality supplies. The new Central American crops were reduced by adverse weather and less attention from growers because of recent low prices. (Buchanan, 2003)

Flat prices and increasing competition in specialty markets makes the future of the coffee industry uncertain. International market prospects for Dominican coffee producers and the entire coffee sector should improve (from a very bad situation) in the short term, but long-run prospects for a return to conditions of the mid-1990s are not expected. An opportunity exists to expand exports to markets demanding higher quality coffee, but these markets are becoming more saturated as competition increases.

\section{B. Recent Cocoa Prices, Production and Exports ${ }^{24}$}

Like international coffee markets, the international cocoa market is experiencing a "crisis", however the "cocoa crisis" is characterized by 30-year high prices (about $\$ 1880 / \mathrm{MT}$ ) and significant declines in global supply. The latter is due to political turmoil in Cote d'Ivoire, the world's major producer and exporter ${ }^{25}$, and to outbreaks of diseases, such as witch's broom. In

${ }^{24}$ This section is drawn mostly from the FAO's Cocoa Commodity Notes, which was last updated March 2003. see the FAO website: fao.org

${ }^{25}$ Cote d'Ivoire accounted for about $45 \%$ of global cocoa production during the 1990 s. For sake of comparison, during the 1990s, Dominican Republic's share of global cocoa production was less than $2 \%$, and the average production was about 50,000 MT 
contrast to coffee, most of the causes of the crisis related to cocoa are more temporary in nature. The international cocoa situation is characterized by high prices, with high uncertainty about the future. International cocoa prices have a long history of wide year-to-year fluctuations.

When observing the current price spikes, it is important to recall that cocoa prices had been in a long-term downward trend in real terms since the last price peak in the mid-1970s. Nominal cocoa prices have returned to their highest level since the late 1980s.

In 2002 the International Cocoa Organization's (ICCO) daily price averaged about \$US 1800 per MT, almost 63\% higher than in 2001 and double the average price in 2000 (which, at that time, had reached a 30-yeard low). Preliminary forecasts for 2002/3 predict a third consecutive year of a global supply shortfall, even though higher production is expected from some countries in Africa.

The decrease in global production and resulting undersupply has led to reduction of stocks. In $2001 / 2$, stocks of cocoa beans declined by $5 \%$. The world stocks-to-grindings (i.e., processing) ratio, a proxy for global cocoa availability, was about 38\%, the same level as it was in 2000/1, reflecting a second year of supply shortfall. Stock levels of intermediate cocoa products, such as cocoa butter, cake and powder also declined.

Figure II.2: Cocoa Prices adjusted for Manufacturing Unit Values 1970-2002

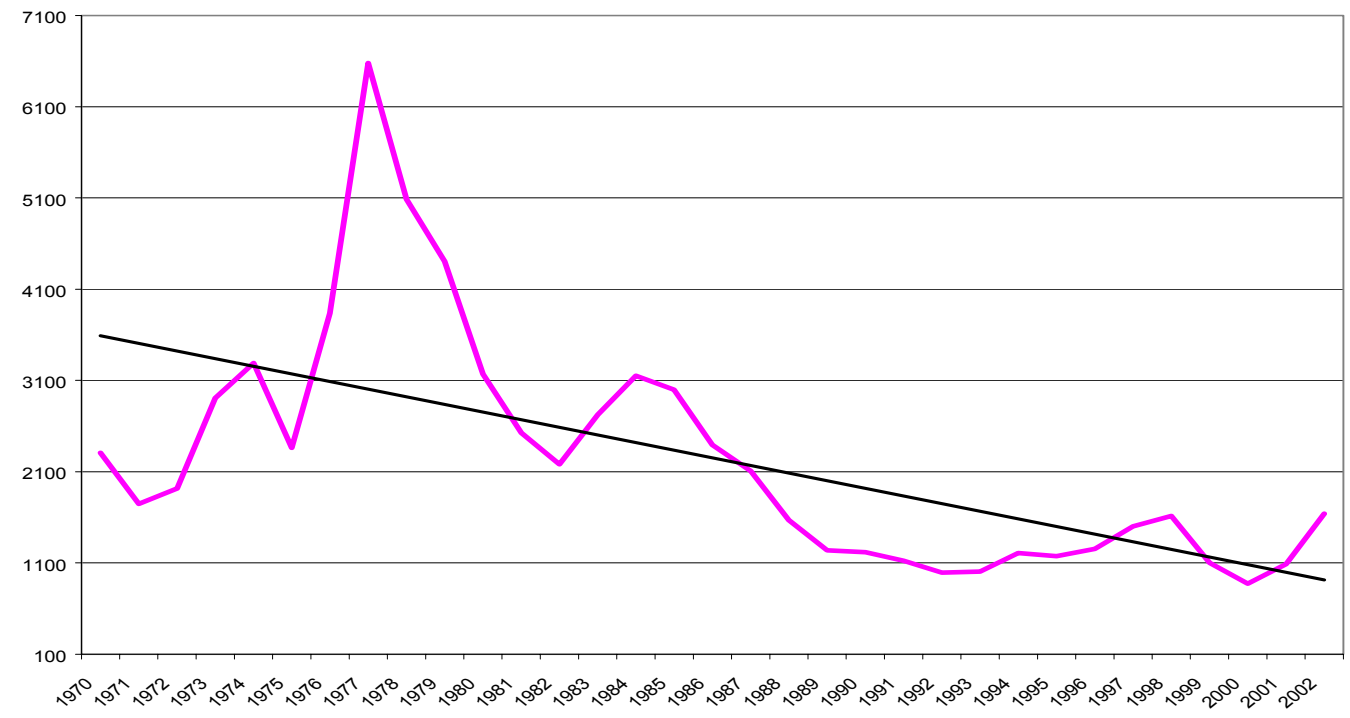

Sources: Cocoa Prices (ICCO) Manufacturing Unit Values (World Bank)

A recent development that could have major repercussions for international markets is the liberalization of the cocoa sector in Cote d'Ivoire. The regulatory framework of the cocoa sector in Cote d'Ivoire was liberalized in August 1999. Deregulation of the cocoa sector coincided with the sharp decline in cocoa prices during the 1990s that bottomed out in 2000. Many changes occurred in Ivorian markets and, as a result, Cote d'Ivoire's cocoa production in 1999/2000 reached a record high just prior to the beginning of civil unrest.

Global demand for cocoa can be approximated by FAO data for "grindings" (processed cocoa beans). The average annual growth rate for cocoa grindings were steady at about $2 \%$ for the 10 - 
year period 1992 to 2001, slightly above the annual growth rate in global population. No radical changes are anticipated in aggregate demand. Despite relatively flat prospects for global demand growth, an expansion in demand for specialty and "issue" cocoa is expected. Since child labor in cocoa production has become a major issue in West Africa, "child labor free" cocoa might be able to fetch a premium. Environmentally friendly and organic cocoa have small markets relative to coffee, but they are expected to expand.

The future of cocoa production and exports is unpredictable. Many countries are responding to the recent price increases by planting more trees. As these trees take up to six years to reach full production potential, oversupply may result in the future. The situation in Cote d'Ivoire, the supply responses in a liberalized cocoa market with entry of large multi-national companies contribute to the uncertainty. Short-term expectations are that international cocoa prices will remain at high levels for at least the next year.

Table II.2 World Cocoa Prices, Production and Grindings 1992/3 - 2001/2

\begin{tabular}{|l|l|l|l|l|l|l|}
\hline & $\begin{array}{l}\text { Avg. } \\
1992 / 93- \\
1996 / 96\end{array}$ & $1997 / 98$ & $1998 / 99$ & $1999 /{ }^{\prime} 00$ & $\begin{array}{l}2000 / 1 \\
\text { (est.) }\end{array}$ & $\begin{array}{l}2001 / 2 \\
\text { (est.) }\end{array}$ \\
\hline Average Annual Price \$USD/MT & & $1,660 *$ & 1,140 & 888 & 1,089 & 1,778 \\
\hline & & & & & & \\
\hline Production & 2,579 & 2,690 & 2,808 & 3,073 & 2,850 & 2,800 \\
\hline $\begin{array}{l}\text { World Total } \\
\text { '000 MT }\end{array}$ & 2,579 & 2,690 & 2,808 & 3,073 & 2,850 & 2,800 \\
\hline Cote d'Ivoire Share & $37.2 \%$ & $41.4 \%$ & $41.4 \%$ & $45.9 \%$ & $32.8 \%$ & $42.3 \%$ \\
\hline Dominican Republic Share & $2.1 \%$ & $2.6 \%$ & $0.9 \%$ & $1.2 \%$ & & \\
\hline & & & & & & \\
\hline Grindings & & & & & & 2,900 \\
\hline $\begin{array}{l}\text { World Total } \\
\text { '000 MT }\end{array}$ & 2,578 & 2,764 & 2,762 & 2,967 & 3,100 & \\
\hline European Share & $50 \%$ & $47 \%$ & $46 \%$ & $46 \%$ & & \\
\hline US Share & $13 \%$ & $14 \%$ & $15 \%$ & $15 \%$ & & \\
\hline Cocoa Producing Countries Share & $29 \%$ & $30 \%$ & $32 \%$ & $32 \%$ & & \\
\hline
\end{tabular}

Source: FAO website.

\section{Dominican Republic's Position in World Cocoa Markets}

The Dominican Republic is among the ten largest cocoa producers in the world (it was the $8^{\text {th }}$ largest producer from 1992/93-1996/97), and the third largest producer in Latin America behind Brazil and Ecuador (see table II.3). However, since 1992, the Dominican Republic has had only 1 to $2.5 \%$ of the world share of production and a similar share of world exports. The world's leading cocoa producer, Cote D'Ivoire had a $37 \%$ to $46 \%$ share of production, and the major four producers - Cote d'Ivoire, Ghana, Indonesia and Brazil a $65 \%$ - $77 \%$ share. Although its share in global cocoa markets is small in the aggregate, it is a "major player" in the organic cocoa market - accounting for approximately $60 \%$ of trade in organics. 
Table II.3 Shares of World Cocoa Production /1992/93 - 1996/97

\begin{tabular}{|l|l|l|l|l|l|}
\hline & Country & $\begin{array}{l}\text { Avg. } \\
1992 / 1993- \\
1996 / 1997\end{array}$ & $1997 / 1998$ & $1998 / 1999$ & $1999 / 2000$ \\
\hline 1 & Cote d'Ivioire & $37.2 \%$ & $41.4 \%$ & $41.4 \%$ & $45.9 \%$ \\
\hline 2 & Ghana & $12.5 \%$ & $15.2 \%$ & $14.1 \%$ & $14.2 \%$ \\
\hline 3 & Indonesia & $10.5 \%$ & $12.3 \%$ & $4.9 \%$ & $13.3 \%$ \\
\hline 4 & Brazil & $9.5 \%$ & $6.3 \%$ & $4.9 \%$ & $4.0 \%$ \\
\hline \multicolumn{1}{|c|}{ Subtotal 1 } & $\mathbf{6 9 . 7 \%}$ & $\mathbf{7 5 . 2 \%}$ & $\mathbf{6 5 . 3 \%}$ & $\mathbf{7 7 . 4 \%}$ \\
\hline 5 & Malaysia & $5.9 \%$ & $2.4 \%$ & $2.7 \%$ & $1.5 \%$ \\
\hline 6 & Nigeria & $5.7 \%$ & $6.1 \%$ & $7.1 \%$ & $5.4 \%$ \\
\hline 7 & Ecuador & $3.3 \%$ & $1.1 \%$ & $2.7 \%$ & $3.1 \%$ \\
\hline 8 & Dominican Republic & $2.1 \%$ & $2.6 \%$ & $0.9 \%$ & $1.2 \%$ \\
\hline 9 & Columbia & $1.9 \%$ & $1.4 \%$ & $1.4 \%$ & $1.2 \%$ \\
\hline 10 & México & $1.7 \%$ & $1.3 \%$ & $1.3 \%$ & $1.2 \%$ \\
\hline & Subtotal 2 & $\mathbf{2 0 . 6 \%}$ & $\mathbf{1 4 . 9 \%}$ & $\mathbf{1 6 . 1 \%}$ & $\mathbf{1 3 . 6 \%}$ \\
\hline & Subtotal 3 (1+2) & $\mathbf{9 0 . 3 \%}$ & $\mathbf{9 0 . 1 \%}$ & $\mathbf{8 1 . 4 \%}$ & $\mathbf{9 1 . 0 \%}$ \\
\hline 11 & Papau New Guinea & $1.3 \%$ & $1.1 \%$ & $1.3 \%$ & $1.5 \%$ \\
\hline & & & & & 3,073 \\
\hline & Quantity Produced in & 2,579 & 2,690 & 2,808 & \\
\hline
\end{tabular}

Source: ICCO (2001) “ICCO Annual Report for 1999/00”. London.

\section{Comparing the Situation in Coffee and Cocoa Markets}

Global coffee and cocoa markets are experiencing "crises." Although coffee prices have sharply fallen and cocoa sharply risen, the future is uncertain for both. Large-scale investments in either sector would be risky. Long-term trends of expanding global production (and declining real prices) need to be juxtaposed against slowly growing demands, and changes in markets. Niche markets are growing and market premiums for certain attributes are more possible now than ever. A major feature of changing demand is the demand for some "differentiable product" and the willingness of consumers to pay a premium. The markets for specialty products are better developed for coffee than for cocoa. Potential for expansion into these "niche markets" exists. But, many coffee and cocoa producers are seeking the same "silver bullet," and with wellintentioned support from international development agencies, donors, and NGOs, competition for these "niche markets" will increase. This competitions is particularly relevant for the coffee and cocoa sectors of Dominican Republic, where there has been a long-time emphasis on the need to improve quality, to expand certified organic production, and target other specialty and niche markets. 


\section{Overview of the Dominican Coffee Sector}

An overview of the coffee sector in Dominican Republic is presented in this chapter. Data and other information are drawn from various publications and public data bases. Expert opinion was also elicited. In addition, we refer to a survey of coffee (and cocoa) producers carried out by the World Bank's Commodity Risk Management Group (CRMG) in mid-2002. ${ }^{26}$ This survey of about 300 coffee (and 300 cocoa) producers is not statistically representative of all coffee (cocoa) producers in the Dominican Republic, and contains a relatively higher proportion of medium and larger-scale producers. The survey, however, illustrates some of the conditions faced by coffee (and cocoa) producers and information and analysis from it are used throughout the text. We refer to this survey as the "CRMG" survey. Details on the survey, including the sample, survey instrument and descriptive statistics can be found in World Bank (2002a). Econometric analyses using the survey data are referred to as CRMG (2003).

\section{A. Trends in Production and Exports}

Coffee was introduced to the Dominican Republic as early as 1715 , and since then has continued to be an important crop among small-scale farmers. Coffee is currently grown by 40,000 to 50,000 producers in the Dominican Republic, on about 120,000 hectares (table III.1). ${ }^{27}$ These numbers represent about $20 \%$ of all agricultural producers and about $3 \%$ of land under cultivation. Since 1981, the number of farms producing coffee has decreased by about $39 \%$ and the area devoted to coffee production declined by about $22 \%$, so average farm size has increased marginally.

Table III.1 Number of Farms and Area under Coffee Cultivation, 1981 and 1999

\begin{tabular}{|l|l|r|r|r|}
\hline & \multicolumn{1}{|c|}{ Unit } & \multicolumn{1}{c|}{1981} & \multicolumn{1}{c|}{1999} & \multicolumn{1}{c|}{ Change $\%$} \\
\hline Number of Farms & & 71,235 & 43,613 & $-39 \%$ \\
\hline $\begin{array}{l}\text { Area under Coffee } \\
\text { Cultivation }\end{array}$ & Tareas & $2,428,418$ & $1,883,445$ & $-22 \%$ \\
& Hectares & 152,731 & 118,456 & \\
\hline
\end{tabular}

Sources: 1981: National Agricultural Census. 1999: SEA, National Registry of Producers.

The significant reduction in the number of producers and land devoted to coffee production has not translated into a sharp decline in total national production. The data indicate the exit of lower productivity coffee producers and the adoption of improved technology by those continuing to produce (see table III.2). ${ }^{28}$ Average yields based on total land area and total production, however, remain relatively low.

\footnotetext{
${ }^{26}$ The survey was conducted in the cocoa growing regions of the Dominican Republic by the Commodity Risk Management Group (CRMG), Agriculture and Rural Development in conjunction with Centro Para el Desarrollo Agropecuario y Forestal, Inc (CEDAF) from May 20 ${ }^{\text {th }}$ to June $7^{\text {th }} 2002$.

${ }^{27}$ Data on the number of coffee producers and land under cultivation vary by source (e.g., whether from SEA, the Department of Coffee, or the Coffee Council). Because the sector is characterized by small scale producing units and coffee is often inter-planted with other crops, it is difficult to carry out nationwide inventories of producers, or even to define "coffee farms".

${ }^{28}$ Table III. 2 shows a 20\% increase in yields over an 18 year period. Data on coffee yields are contradictory. The FAO data base (FAO/AgStat) indicates a 30\% decline in DR coffee yields between 1980 and 2000 (from 364 to $264 \mathrm{~kg} /$ hectare). Over the same period, FAO shows yields in Colombia growing by $23 \%$ and yields in Brazil growing by over $130 \%$.
} 
Table III.2 Average Coffee Yields, 1981 and 1999

\begin{tabular}{|c|c|c|c|}
\hline \multirow[t]{2}{*}{ Year } & Area under Cultivation & Yield per & \multirow{2}{*}{$\begin{array}{l}\text { Production Green Coffee } \\
\text { Hundredweights, qq } \\
\text { (Metric Tons, MT). }\end{array}$} \\
\hline & $\begin{array}{l}\text { Tareas } \\
\text { (Hectares) }\end{array}$ & $\begin{array}{l}\text { Tarea } \\
(\text { Hectare) }\end{array}$ & \\
\hline 1981 & $\begin{array}{l}2,428,418 \text { tareas } \\
(152,731 \mathrm{ha})\end{array}$ & $\begin{array}{l}0.44 \mathrm{qq} / \mathrm{ta} \\
350 \mathrm{~kg} / \mathrm{ha}\end{array}$ & $\begin{array}{l}1,075,400 \mathrm{qq} \\
(53,770 \mathrm{MT})\end{array}$ \\
\hline 1999 & $\begin{array}{l}1,883,455 \text { tareas } \\
(118,456 \mathrm{ha})\end{array}$ & $\begin{array}{l}0.53 \mathrm{qq} / \mathrm{ta} \\
420 \mathrm{~kg} / \mathrm{ha}\end{array}$ & $\begin{array}{l}1,004,100 \mathrm{qq} \\
(50,205 \mathrm{MT})\end{array}$ \\
\hline
\end{tabular}

1981: National Agricultural Census and Coffee Growing Statistics.

1998: National Producers Registry and Production Statistics.

\section{B. Geography and Ecology of Production}

Coffee production is distributed among the Dominican Republic's eight agricultural regions (see Map Annex), but five major coffee producing zones can be identified. Of these, the four most important are located in the main mountainous areas of the country: the Central Mountain Range, the Northern Mountain Range, the Neyba Mountain Range, and the Bahoruco Mountain Range. These mountainous areas are all located in critical watershed areas, and land use on these mountains has major and far reaching environmental impacts.

The Central and Southern Region agricultural regions, located in the center of the south of the Central Mountain Range and the north of the Neyba Mountain Range represents 44\% of the total coffee land area and $37 \%$ of the coffee farms (table III.3). The Northern Region, located in the center of the Northern Mountain Range, and part of the northwest slope of the Central Mountain Range, represents $24 \%$ of the total coffee land area and about $25 \%$ of the coffee farms. The North Central Region, located in the center of the north of the central range, represents $13 \%$ of the total coffee land area and $14 \%$ of the coffee farms. The Southeastern Region, located in the center of the Bahoruco Mountain Range, and to the south of the Neyba Mountain Range has the least favorable coffee growing conditions and is the only area of Dominican Republic where Robusta coffee is produced.

Table III. 3 Coffee Farms and Land Area Under Coffee Cultivation by Agricultural Region

\begin{tabular}{|l|r|r|r|r|r|}
\hline \multirow{2}{*}{$\begin{array}{c}\text { AGRICULTURAL } \\
\text { REGION }\end{array}$} & \multicolumn{2}{|c|}{ NUMBER OF FARMS } & \multicolumn{2}{c}{ AREA UNDER CULTIVATION } \\
\cline { 2 - 6 } NORTH & \multicolumn{1}{c|}{ Units } & \multicolumn{1}{c}{ Tareas } & Hectares & $\%$ \\
\hline CENTRAL & 10,986 & 25.2 & 450,897 & 28,358 & 23.9 \\
\hline SOUTHERN & 10,092 & 23.1 & 449,390 & 28,264 & 23.9 \\
\hline NORTH CENTRAL & 6,049 & 13.9 & 371,604 & 23,371 & 19.7 \\
\hline SOUTHWEST & 6,132 & 14.1 & 245,601 & 15,447 & 13.0 \\
\hline NORTH EAST & 3,969 & 9.1 & 168,380 & 10,590 & 9.0 \\
\hline NORTH WEST & 4,148 & 9.5 & 105,096 & 6,610 & 5.6 \\
\hline EAST & 1,383 & 3.2 & 72,889 & 4,584 & 3.9 \\
\hline NATIONAL TOTAL & 855 & 2.0 & 19,588 & 1,232 & 1.0 \\
\hline
\end{tabular}

Source: SEA, National Registry of Agricultural Producers, 1999. Preliminary Data. Agricultural region is an administrative area defined by government

Estimates of the number of farms by regions based on the cross of variables and farms by strata and surface area.

Dominican coffee growing areas are mostly classified as subtropical humid forest to subtropical high humid forest. Most soils belong to the land capability class VII, corresponding to steep 
slopes and limited soil depth, and they are subject to erosion if not properly managed. In many coffee producing areas, transport and communication are constrained by the rough terrain. Access to most villages is provided by secondary roads, and farms scattered through the area are linked to villages by mule paths. The hilly areas where coffee is grown are subject to erosion. Dense coffee plantings on the contours under shade trees, and coffee inter-planted with trees provide good protection against soil erosion.

The Dominican Republic has the natural conditions to produce high-altitude, good quality coffee. ${ }^{29}$ Coffee production areas can be broken down into three general zones: (a) optimal areas - excellent soil, proper temperature, high elevation (800-1300 meters) and high rainfall, (b) goodadequate areas - good soil, moderate temperature, medium elevation (600-800 meters), adequate rain, and (c) marginal areas - poor soil, high temperature, low elevation $(<500$ meters above sea level in the north, $<600$ meters in the south), inadequate rain. About $25 \%$ of the coffee land is found in optimal areas, about $60 \%$ in the good-adequate areas and only about $15 \%$ in marginal areas. More details on farm sizes, areas planted with coffee and elevation are presented below.

The Dominican Republic grows almost entirely Arabica coffee (classified in international markets as "milds") with small amounts of Robusta for internal consumption (only $3.3 \%$ of total producers and $1.3 \%$ of land area are involved in robusta). See table III.4. There are two main varieties of Dominican Arabica coffee: tipica and caturra. Tipica is a traditional, older variety higher quality coffee, with relatively lower yields. Tipica grows on tall, spindly trees (about $3 \mathrm{~m}$ in height) that are susceptible to hurricane damage. Caturra is a newer variety that produces harvests earlier with higher yields, but has smaller beans and lower quality coffee. Caturra is smaller and bushier than tipica and less susceptible to hurricanes. Caturra can be grown in pure stands without shade, enabling easier applications of agri-chemicals. Over the last 20 years, farmers were encouraged by government and coffee-related NGOs to shift from tipica to caturra. This shift was a major focus of the World Bank's Cocoa and Coffee Project. Catuai is another improved coffee variety that has more recently been introduced (it is a cross between Caturra and Borboun).

As of 2000 , about $75 \%$ of coffee producers had only tipica trees and about $64 \%$ of land area was under tipica (table III.4). Only about $5 \%$ of coffee producers and $8 \%$ of the land area are devoted to pure stands of caturra and mixed tipica and caturra account for $16 \%$ of producers and $27 \%$ of land area. The production of Caturra coffee is related to farm size; the CRMG survey shows that about $25 \%$ of the smallest producing units $(<5$ hectares) produced caturra varieties, compared to $38 \%$ of medium-sized (5-10 hectares) and $44 \%$ of producers with more than 10 hectares.

Over the past 20 years, several trends in Dominican coffee production have emerged: (a) increased caturra production, (b) increased inter planting of caturra and tipica varieties, (c) increased concentration of coffee at higher elevations with a corresponding reduction in lowelevation farms, and d) diversification of coffee plantations to include other fruit trees and alternative shade trees. The implication of increased caturra production is higher yield but lower coffee quality (especially if trees are not well-attended to). As a part of recent efforts to improve quality, the government has begun to encourage producers to switch back to tipica. ${ }^{30}$ Caturra varieties were also found to be susceptible to leaf rust, a fungus that appeared in Dominican Republic in the late 1980s (World Bank, 1991).

\footnotetext{
${ }^{29}$ Coffee is not typically grown above 1400 meters because of low temperatures. For the tipica variety of coffee (see below) this upper ceiling for production is only about 1100 meters.

${ }^{30}$ SOFRECO (2001), p.9. In fact, many of the efforts to rehabilitate following Hurricane Georges involved planting of tipica varieties.
} 
Table III.4 Shares of Coffee Producers by Variety, 2001

\begin{tabular}{|c|c|c|}
\hline & \multicolumn{2}{|c|}{ Percentage } \\
\hline Variety & Producers & Land Area \\
\hline Tipica & $75 \%$ & $64 \%$ \\
\hline Caturra & $5 \%$ & $8 \%$ \\
\hline Both & $16 \%$ & $27 \%$ \\
\hline Robusta & $3 \%$ & $1 \%$ \\
\hline Total & $100 \%$ & $100 \%$ \\
\hline
\end{tabular}

Source: Inventario de Caficultores Resultados, Consejo Dominicano de Café, Republica Dominicana (2002).

Inter-planting of caturra and tipica varieties has led to heterogeneous bean quality and problems in marketing high-quality Dominican coffee; as discussed below, negative price premiums on Dominican coffee are found in international markets. The third trend has two implications. First, the largest, most technologically advanced coffee plantations are found between 1,300 and 1,400 meters (relatively high elevations), and improved technology and farm size may contribute to more efficient production. Second, caturra production at high elevations has fewer positive environmental externalities associated with it compared to tipica production. Caturra is generally not produced under shade; and the shade production widely prevalent in tipica plantations significantly helps reduce soil erosion and enhances surface and ground water quality. More erosive practices at high elevations can reduce the environmental benefits associated with coffee production. Also, as mentioned previously, caturra production is associated with higher use of fertilizer and other agri-chemicals, with potential to have negative environmental impacts. Pure stands of non-shade caturra are mainly confined to the north-eastern part of the country.

\section{Diversification into Fruit Trees: A Program Supported by GoDR}

Fruit tree rehabilitation is being promoted by SEA through the distribution of almost 5 million fruit trees. The fruit sector is being further enhanced through rehabilitation of processing facilities as part of "Programa Especial de Desarrolllo de la Fruiticultura Dominicana." Some of these efforts have been aimed at coffee producers at lower altitudes (who are considered non-competitive). Plans also exist to provide assistance to small scale producers to increase productivity of food crops to diversify production and improve food security..

In recent years, diversification into fruit trees has been encouraged by GoDR for marginal coffee producers at low elevations. This strategy replaces coffee, while maintaining environmental benefits associated with tree plantings. Diversification into fruit tress has been recommended for small coffee producers in good growing areas (EDE, 2002). Diversification is a potential means of increasing the economic potential of their small landholdings, spreading cash and labor flows, reducing price and market risk. ${ }^{31}$ Diversification programs also help by encouraging replacement of overgrown shade trees. Diversified coffee and fruit tree plantations also help prevent pests and diseases, and have the environmental benefits of shade grown coffee. Coffee/fruit tree interplanting helps prevent soil erosion. Leguminous trees have also been suggested for their ability to fix nitrogen and provide organic fertilizer.

\footnotetext{
${ }^{31}$ In this report we raise the issue of diversification and emphasize the potential benefits. Diversification is not, by definition, positive or negative. It depends on the mix of activities that is selected. See Varangis, Siegel, Giovannuci, Lewin, 2003 for a detailed discussion on potential benefits and costs associated with diversification of coffee production.
} 
According to the CRMG survey, almost all coffee in the Dominican Republic is interplanted. ${ }^{32}$ The tendency to interplant is weakly related to farm sizes; $99 \%$ of the smallest producers reported inter-planting, compared to $95 \%$ in medium holdings and $93 \%$ in the largest $(>10$ hectares) group. Thus, despite different uses of technologies, virtually all producers in the Dominican Republic interplant, but diversified production systems are somewhat more important for smaller producers.

\section{Quantities Produced and Exported}

Dominican coffee production has varied substantially over the past decade, ranging between 72,000 and 125,000 qq or about 32,700 to 57,000 MT (see table III.5). Production variability is associated with pest (primarily broca) and disease problems, Hurricane Georges, and with fluctuating international prices. Hurricane Georges resulted in a production decline of about $40 \%$. Recent price declines have also been associated with steep production declines, and a very sharp drop in the volume and value of coffee exports - especially when compared to the mid-1990s..

Table III.5: Coffee Production and Exports 1990/1-2001/2

\begin{tabular}{|l|r|r|rc|r|r|}
\cline { 2 - 7 } \multicolumn{1}{c|}{} & \multicolumn{2}{|c|}{ Production } & \multicolumn{2}{l|}{ Exports } & \multicolumn{1}{c|}{ Q } \\
\cline { 2 - 7 } \multicolumn{1}{c|}{} & QQ & MT & $\begin{array}{c}\text { \% } \\
\text { Exported }\end{array}$ & QQ & \multicolumn{1}{c|}{ MT } & $\begin{array}{c}\text { Value of } \\
\text { Exports US\$ }\end{array}$ \\
\hline $1990 / 1991$ & 900000 & 40823 & 66 & 597100 & 27084 & $43,241,360$ \\
\hline $1991 / 1992$ & 948000 & 43000 & 44 & 420100 & 19055 & $25,648,700$ \\
\hline $1992 / 1993$ & 922000 & 41821 & 64 & 586100 & 26585 & $32,095,400$ \\
\hline $1993 / 1994$ & 721200 & 32713 & 50 & 362100 & 16425 & $34,126,000$ \\
\hline $1994 / 1995$ & 934900 & 42406 & 61 & 574700 & 26068 & $92,881,300$ \\
\hline $1995 / 1996$ & 1055900 & 47895 & 65 & 691000 & 31343 & $73,752,300$ \\
\hline $1996 / 1997$ & 749500 & 33997 & 53 & 393900 & 17867 & $59,785,900$ \\
\hline $1997 / 1998$ & 1255400 & 56944 & 44 & 553000 & 25084 & $83,211,900$ \\
\hline $1998 / 1999$ & 763000 & 34609 & 28 & 213400 & 9680 & $23,934,000$ \\
\hline $1999 / 2000$ & 1004100 & 45545 & 25 & 250440 & 11360 & $27,432,440$ \\
\hline $2000 / 2001$ & 782100 & 35550 & 17 & 135600 & 6163 & $11,626,400$ \\
\hline $2001 / 2002$ & 822980 & 37408 & 18 & 151600 & 6890 & $12,832,380$ \\
\hline
\end{tabular}

Source: CODOCAFE

Unlike many other coffee-producing countries, the Dominican Republic has a high per capita consumption, of about 5 pounds per year. The 2-3 million tourists who visit the country annually also account for some of this domestic consumption. These tourists drink, buy, and take coffee home. Domestic consumption of coffee has been more stable than production and has slowly increased in recent years, largely a function of population growth. Domestic consumption averaged about $50-75 \%$ of total production during the $1990 \mathrm{~s}$, but, due to sharp declines in exports, the domestic consumption in 2000-2003 has averaged over $80 \%$ of total production. Coffee exports fluctuate more than total production. Export fluctuations are also influenced by the management of coffee stocks by INDUBAN, a company that handles about $95 \%$ of the domestic market and $20 \%$ of exports.

\footnotetext{
${ }^{32}$ According to the CRMG survey, the most popular inter-planted trees were orange, avocado and plantain (about $70 \%$ of producers), followed by mango and lemon (about $20 \%$ of producers). About $12 \%$ of coffee producers inter-planted with cocoa.
} 
The Dominican Republic is a minor player in international coffee markets, with about $0.5-1 \%$ of total global coffee production/exports, and about $1.5-2 \%$ of global production/exports of coffees classified as "milds" (CODOCAFE, 2001). Dominican coffee is principally exported to North America followed by Europe. Between 1990-1999 the North American market received 60\% of coffee exports. During this period European (Italy, Germany, Spain, Holland) countries accounted for $35 \%$ of exports. Italy is the primary consumer of Dominican coffee in Europe (about two-thirds of European exports), and by the late 1990s accounted for $20 \%$ of exports. Asia accounted for about $4 \%$ of exports, but the Japanese are increasing their purchase of Dominican coffee. Dominican exporters have recently increased their sales to other Caribbean countries. For example, Dominican Republic exports some of its coffee to neighboring Puerto Rico, both legally and illegally. In 2000, 63,000 hundredweight of roasted coffee officially passed to Puerto Rico and 2,500-4,000 hundredweight to Jamaica. ${ }^{33}$

Table III.6 Exports of Coffee by Destination, 1990-1999, In Thousands of Dollars - USD\$000

\begin{tabular}{|c|c|c|c|c|c|c|c|c|c|c|c|c|c|c|}
\hline \multirow[t]{2}{*}{ Years } & \multicolumn{4}{|c|}{ NORTH AMERICA } & \multicolumn{4}{|c|}{ EUROPE } & \multicolumn{4}{|c|}{ ASIA } & \multicolumn{2}{|c|}{ TOTAL } \\
\hline & $\begin{array}{l}\text { Sack } \\
60 \mathrm{Kg}\end{array}$ & $\%$ & US\$ & $\%$ & $\begin{array}{l}\text { Sack } \\
60 \mathrm{Kg}\end{array}$ & $\%$ & US\$ & $\%$ & $\begin{array}{l}\text { Sack } \\
60 \mathrm{Kg}\end{array}$ & $\%$ & US\$ & $\%$ & $\begin{array}{l}\text { Sack } \\
60 \mathrm{Kg}\end{array}$ & US\$ \\
\hline 1990-99 & 189.3 & 60.3 & 25,390 & 61.4 & 87.8 & 35.3 & 12,249 & 34.1 & 12.3 & 4.4 & 1,850 & 4.5 & 289.3 & $39,488.60$ \\
\hline
\end{tabular}

Source: Central Bank of Dominican Republic

Most Dominican coffee is sold as mainstream coffees of not particularly high quality, and some international traders classify it as "substandard" (Buzzanell, 2002). Good-quality Dominican coffee is currently traded at a US\$ 4.00 per hundredweight discount on the New York market, but quality penalties can be even higher. Quality problems are caused by poor post-harvest handling, mixing of different quality beans during marketing, unclear grading standards, and failure of the domestic market to reward quality. In the past, Europeans paid a premium for Dominican coffee from the regions of Barahona and Barahoruco, but quality and origin control problems have eliminated this premium. Even Barahona coffee, which is reasonably well known in gourmet trade, is no longer viewed as being of extraordinary high quality.

Several regions of the country, however, have potential for production of higher quality coffee. This potential can only be realized through better marketing standards, a more transparent marketing system and adoption of improved practices on the part of producers. Importers of Dominican coffee are typically looking for three things: a) strong acidity, b) coffee grown at high elevations, and c) distinct smell. The United States has a special niche market by virtue of the substantial numbers of Dominican émigrés. Less than $10 \%$ of Dominican exports go to specialty coffee markets, are certified organic, or are sold under Fair Trade arrangements. There is untapped potential to access these markets and current projects by Agencia Francesa de Desarollo (AFD), USAID ${ }^{34}$ and the International Coffee Partners (ICP) are assisting Dominican producers access these markets. These niche markets are competitive ${ }^{35}$ and other countries in Latin America and Caribbean are targeting them.

Fluctuations in yields prevent producers, producer associations, and even exporters from obtaining long-term fixed quantity-price contracts, and from purchasing forward pricing contracts

\footnotetext{
${ }^{33}$ SOFRECO (2001), p.27.

${ }^{34}$ The USAID Regional Specialty Coffee Project provides technical assistance to producer groups to access specialty markets.

${ }^{35}$ Estimates put the world demand of certified organic coffee at less than 500,000 bags per year (EDE).
} 
based on quantities delivered. As a result, if they choose to access international commodity markets, they need to resort to more expensive types of price hedging instruments such as options. As the international coffee market becomes more competitive, more quality conscious, with more price fluctuations and lower prices, the combination of Dominican Republic's production instability and low quality are a major problem for competitiveness in international markets. This problem is also relevant for the cocoa sector.

A significant challenge to the coffee sector in recent years has been recovery from Hurricane Georges. Much of the country's productive capacity in coffee suffered damage. In the survey undertaken by the CRMG, about $83 \%$ of respondents claimed damages from Georges. The magnitude of the effects stated by respondents increased with farm size. The majority of producers faced between $20 \%$ and $40 \%$ damage to their trees from the Hurricane while less then $20 \%$ of producers were affected seriously. Despite low coffee prices and storm damage, $50 \%$ of those surveyed chose to replant trees after the hurricane.

\section{Structure of production}

The majority of coffee producers in the Dominican Republic operate on small land holdings, but more than half the volume of coffee production is by medium and larger scale producers. The share of smallest landholding sizes among total number of coffee producers and total production has declined over the past 20 years.

Very small producers dominate the sector in terms of the number of producers (table III.7). About $50 \%$ of producers have less than 1.25 hectares, but they account for only about $12 \%$ of coffee area. Approximately $30 \%$ all of coffee producers have less than 0.625 ha. Alternatively, coffee producers with more than 6.25 ha account for about $6 \%$ of the farms and about $36 \%$ of land areas devoted to coffee. About $27 \%$ of coffee producers are located below $500 \mathrm{~m}$, but this includes a relatively high percentage of small sized producers (table III.8). Medium and larger sized producers tend to be located at higher elevations, where higher-quality coffee is produced.

Table III .7 Coffee Farm Size and Numbers of Producers

\begin{tabular}{|c|c|c|c|c|c|}
\hline \begin{tabular}{|c|c|c|c|} 
LAND SIZE \\
AREA
\end{tabular} & $\begin{array}{c}\text { LAND SIZE } \\
\text { by HECTARE } \\
\text { (approximate) }\end{array}$ & $\begin{array}{c}\text { NUMBER OF } \\
\text { FARMS }\end{array}$ & $\begin{array}{c}\% \text { OF } \\
\text { FARMS }\end{array}$ & $\begin{array}{c}\text { CULTIVATED AREA } \\
\text { Tareas } \\
\text { (Hectares) }\end{array}$ & $\begin{array}{c}\text { \% OF } \\
\text { AREA }\end{array}$ \\
\hline $1-10$ & $0-0.62$ & 13,248 & 30.4 & $\begin{array}{c}83,705 \\
(5,264)\end{array}$ & 4.5 \\
\hline $11-20$ & $0.63-1.25$ & 8,130 & 18.6 & $\begin{array}{c}137,926 \\
(8,675)\end{array}$ & 7.3 \\
\hline $21-50$ & $1.26-3.14$ & 12,747 & 29.2 & $\begin{array}{l}467,061 \\
(29,375)\end{array}$ & 24.8 \\
\hline $51-100$ & $3.15-6.25$ & 6,777 & 15.5 & $\begin{array}{l}510,418 \\
(32,102)\end{array}$ & 27.1 \\
\hline $101+$ & $6.26+$ & 2,711 & 6.2 & $\begin{array}{l}684,345 \\
(43,041)\end{array}$ & $36.3 \%$ \\
\hline \multicolumn{2}{|c|}{ TOTAL } & 43,613 & $100 \%$ & $\begin{array}{l}1,883,455 \\
(118,456)\end{array}$ & $100 \%$ \\
\hline
\end{tabular}


Table III.8 Shares of Farm Sizes and Land Areas by Elevation

\begin{tabular}{|c|c|c|c|c|c|c|c|c|c|}
\hline \multicolumn{2}{|c|}{ Groupings } & \multicolumn{2}{|c|}{$>900$ MSNM } & \multicolumn{2}{|c|}{ 500-900 MSNM } & \multicolumn{2}{|c|}{$<500$ MSNM } & \multicolumn{2}{|c|}{ Total } \\
\hline Hectares & Tareas & $\begin{array}{l}\text { Share of } \\
\text { Farmers }\end{array}$ & $\begin{array}{l}\text { Share of } \\
\text { Land }\end{array}$ & $\begin{array}{l}\text { Share of } \\
\text { Farmers }\end{array}$ & $\begin{array}{l}\text { Share } \\
\text { of Land }\end{array}$ & $\begin{array}{l}\text { Share of } \\
\text { Farmers }\end{array}$ & $\begin{array}{l}\text { Share } \\
\text { of } \\
\text { Land }\end{array}$ & $\begin{array}{l}\text { Share of } \\
\text { Farmers }\end{array}$ & $\begin{array}{l}\text { Share of } \\
\text { Land }\end{array}$ \\
\hline $0-0.6$ & $1-9$ & $3.6 \%$ & $0.5 \%$ & $8.0 \%$ & $1.0 \%$ & $4.4 \%$ & $0.3 \%$ & $15.9 \%$ & $1.8 \%$ \\
\hline $0.6-1.2$ & 10-19 & $4.6 \%$ & $1.7 \%$ & $10.2 \%$ & $3.2 \%$ & $5.6 \%$ & $1.1 \%$ & $20.5 \%$ & $6.0 \%$ \\
\hline $1.3-3.1$ & $20-49$ & $7.8 \%$ & $6.9 \%$ & $17.2 \%$ & $13.0 \%$ & $9.5 \%$ & $4.3 \%$ & $34.5 \%$ & $24.3 \%$ \\
\hline $3.1-6.2$ & $50-99$ & $4.7 \%$ & $8.8 \%$ & $10.4 \%$ & $1.6 \%$ & $5.7 \%$ & $5.6 \%$ & $20.8 \%$ & $31.0 \%$ \\
\hline $6.3-12.5$ & 100-199 & $1.4 \%$ & $4.8 \%$ & $3.0 \%$ & $9.1 \%$ & $1.7 \%$ & $3.0 \%$ & $6.1 \%$ & $17.0 \%$ \\
\hline $12.6-18.8$ & 200-299 & $0.3 \%$ & $1.9 \%$ & $0.6 \%$ & $3.5 \%$ & $0.4 \%$ & $1.2 \%$ & $1.3 \%$ & $6.5 \%$ \\
\hline$>18.8$ & $>300$ & $0.2 \%$ & $3.7 \%$ & $0.5 \%$ & $7.1 \%$ & $0.3 \%$ & $2.5 \%$ & $0.9 \%$ & $13.4 \%$ \\
\hline TOTAL & & $22.7 \%$ & $28.3 \%$ & $49.9 \%$ & $53.6 \%$ & $27.4 \%$ & $18.0 \%$ & $100 \%$ & $100 \%$ \\
\hline
\end{tabular}

Source: Inventario Nacional de Caficultores Resultados, Consejo Dominicano Del Café, Republica Dominicana 2002

\section{D.2 Cultivation Practices and Technology}

Coffee producers in the Dominican Republic use heterogeneous cultivation practices and technologies. Harvest and post-harvest technologies also vary by type of producer. Traditional coffee growing is characterized by low levels of technology and low productivity with the traditional tipica variety. Traditional coffee production systems usually include shade trees and inter-cropping. Cultural practices are limited to weed control and occasional fertilization. Young trees are not shaped by pruning and production pruning is limited to clearing branches when the plantation is too thick. Many coffee plantations are old, with varying plant density, no planting pattern, and often excessive shade. The excess shade occurs because it is difficult to prune the tall Erythrina trees that predominate. Use of fertilizers and pesticides is predominantly limited to larger producers. About $75 \%$ of land used for coffee production uses "traditional" low-input and low productivity technologies, shade grown, and produced with household labor (see table III.9). Much of this coffee production is located in marginal zones, but some is located in areas with good/excellent potential. With about $75 \%$ of coffee area, producers using traditional cultivation practices produce only an estimated $30 \%$ of total national coffee output.

Another 15\% of land in coffee production uses "moderate technology" and management. Moderate technology implies use of improved varieties (mixed), pruning and weeding, fertilizer, agri-chemicals, shade grown, mostly household labor, and some seasonal labor. This grouping accounts for about $20 \%$ of production, and includes many of the coffee producers who are members of coffee producer associations. Finally, about $8 \%$ of land uses "technified" methods and business type management and produces about $50 \%$ of the coffee. Producers use intensive cultivation, often with minimal or no shade, with fertilizers, agri-chemicals, and good postharvest practices. "Technified" coffee production has a relatively high reliance on hired labor.

\section{Coffee Production and Household Income}

As discussed previously, a large proportion of coffee producers inter-plant coffee trees with other trees or crops. This diversity within the coffee plantation allows for a diversification of incomes sources, which can potentially lead to better management of labor and cash flows, and improve the management of risks due to fluctuating coffee prices or yields. Since a high percentage of 
coffee producers have small landholdings, income-generating activities are needed to supplement coffee incomes. In fact, many small-scale coffee producers rely on their coffee trees as "banks"-a source of cash that supplements other income generating activities. With more alternative income generating activities, smaller-scale producers can manage their plantations in a manner that is responsive to international coffee prices - when prices are high they devote more labor to maintenance activities and harvest, and when prices are low they do less. This type of supply response causes coffee production to fluctuate from year to year. A similar situation exists for small-scale cocoa producers.

The high degree of diversity in income generation among coffee-producing households is confirmed by the CRMG survey. It found that about $61 \%$ of producers received less than $50 \%$ of their family income from farm sources, and only $16 \%$ received $75-100 \%$ of their income from the farm. Coffee is also not the only source of farm income; the CRMG survey found that $63 \%$ of coffee producers receive less than $50 \%$ of their farm income from coffee and less than $15 \%$ received $75-100 \%$ from coffee. The share of total income from farm sources and the share of farm income from coffee were not related to landholding sizes. Thus, for the majority of coffee producers surveyed, coffee only represents a portion of a diversified portfolio of on- and off-farm income sources.

The fact that so many coffee producers have alternative sources of income needs to be taken into account when designing a strategy for the future. Taking a holistic approach that accounts for all household income generating activities and labor flows from on- and off-farm activities (and the risks that producers face) is critical for understanding the receptiveness and responsiveness of coffee producers to different opportunities. A holistic approach is also for important for assessing the profitability and competitiveness of coffee production from a producer's perspective. This is also the case for the cocoa sector.

\section{Coffee Producer Perceptions of Risks}

The primary risks faced by coffee producers are weather and price-related. The CRMG survey asked producers to score several risks in terms of their importance. Risk associated with coffee price was ranked first, but closely followed by risks associated with weather, diseases and pests, household health, and access to credit (all were scored 2.5 and above on a 1 to 3 scale where 1 was not important, 2 important, and 3 very important). Reduction in yields from other crops and employment sources were scored as less important. No significant variation in response emerged by landholding size. Thus, coffee producers perceive that they are operating in a very risky environment. In reaction to the current coffee price crisis, a high proportion of producers responded that they are reducing the use of inputs, hired labor and, in some cases, not harvesting their coffee. Many also indicated that they are having difficulty repaying their debts. These reactions to the current coffee price crisis indicate that there are potential negative impacts that extend beyond producers; to others directly and indirectly linked to the sector. 
Table III.9: Typology of Technology and Cultivation Practices for Coffee, and Shares of Land Area and Production

\begin{tabular}{|c|c|c|c|c|}
\hline Typology & $\begin{array}{c}\text { Characteristics of Technology } \\
\text { and Cultivation }\end{array}$ & $\begin{array}{l}\text { Land Area } \\
\text { under Coffee }\end{array}$ & $\begin{array}{c}\text { Production } \\
\text { Quantity and } \\
\text { Share of } \\
\text { National } \\
\text { Production }\end{array}$ & $\begin{array}{c}\text { Yield per } \\
\text { Tarea and } \\
\text { Hectare }\end{array}$ \\
\hline $\begin{array}{l}\text { Technified } \\
\text { and/or Modern }\end{array}$ & $\begin{array}{l}\text { Intensive cultivation of caturra } \\
\text { and catuaí varieties. Density of } \\
\text { planting } 5000 \text { plants/ha. } \\
\text { Systematic management of } \\
\text { fertilization, pruning, and } \\
\text { phytosanitary control. Generally } \\
\text { cultivated in full sunlight. } \\
\text { Business type management. } \\
\text { Post-harvest practices on-farm } \\
\text { mechanized wet-milling or } \\
\text { commercial milling }\end{array}$ & $\begin{array}{l}\text { Approximately } \\
8 \% \text { of land area }\end{array}$ & $\begin{array}{l}\text { Approximately } \\
50 \% \text { of the } \\
\text { National } \\
\text { Production. }\end{array}$ & $\begin{array}{l}2 \mathrm{qq} / \mathrm{ta} \\
(1,600 \mathrm{~kg} / \mathrm{ha})\end{array}$ \\
\hline $\begin{array}{l}\text { Moderately } \\
\text { Technified }\end{array}$ & $\begin{array}{l}\text { The majority cultivates typical } \\
\text { variety combined with caturra. } \\
\text { Relative deficiency in } \\
\text { management of pruning, } \\
\text { fertilization and control of shade. } \\
\text { Combines family type with } \\
\text { temporary labor. } \\
\text { Post-harvest practices: on-farm } \\
\text { simple technology, or } \\
\text { commercial milling }\end{array}$ & $\begin{array}{l}\text { Approximately } \\
16 \% \text { of land } \\
\text { area }\end{array}$ & $\begin{array}{l}\text { Approximately } \\
20 \% \text { of the } \\
\text { National } \\
\text { Production. }\end{array}$ & $\begin{array}{l}0.6 \mathrm{qq} / \mathrm{ta} \\
(440 \mathrm{~kg} / \mathrm{ha})\end{array}$ \\
\hline Traditional & $\begin{array}{l}\text { Mainly cultivates typical. } \\
\text { Plantations very old. Many plots } \\
\text { located in marginal zones. } \\
\text { Minimal management in terms of } \\
\text { techniques and technology. } \\
\text { Post-harvest practices on-farm } \\
\text { traditional milling. }\end{array}$ & $\begin{array}{l}\text { Approximately } \\
76 \% \text { of land } \\
\text { area }\end{array}$ & $\begin{array}{l}\text { Approximately } \\
30 \% \text { of the } \\
\text { National } \\
\text { Production. }\end{array}$ & $\begin{array}{l}0.18 \mathrm{qq} / \mathrm{ta} \\
(140 \mathrm{~kg} / \mathrm{ha})\end{array}$ \\
\hline
\end{tabular}

Source: Prepared by the authors based on interviews.

\section{Diseases and Pests}

Diseases and pests have traditionally not been a major problem for coffee production in the Dominican Republic (World Bank, 1981). Periodic outbreaks have usually quickly come under control such as leaf rust outbreak in the late 1980s (World Bank, 1991). The relatively dry winter accounts for the low incidence of disease. As a result of low prevalence of diseases, many traditional producers have long practiced a form of organic coffee production. In most cases, however, these growers have not been "certified" as such. Leaf rust fungus and the broca (the coffee berry borer) insect became serious problems because of lack of previous exposure to such risks and the lack appropriate control practices. In recent years coffee production has been 
negatively impacted by broca. Broca is a small insect that bores into coffee cherries and lays eggs. The larvae feed on the bean, destroying the coffee.

Based on the CRMG producer survey, broca had far reaching effects; $98 \%$ of producers surveyed claimed to be affected by broca. Growers have means of combating the pest, including biological control using parsites and an entomopathogenic fungus, integrated pest management using insect traps, and post-harvest practices. Carefully selected pesticides are only used in emergency situations. These environmentally safe control measures have been successful, and almost $81 \%$ of producers in the CRMG survey claimed to have successfully combated broca.

\section{Labor}

Small-scale farmers rely almost entirely on family labor during the year, with the exception of the harvest period. During harvest, only about $50 \%$ of labor on medium-sized farms is family labor, and lower percentages on larger-sized farms. Most production activities are conducted by males, while wives and female children often assist in harvest and post-harvest activities. Some smallscale farmers also tend to work on larger farms as wage laborers, and many work outside agriculture $^{36}$.

Data on employment in coffee production and harvest/post-harvest are generally unreliable. Most coffee jobs are seasonal, and many are performed by women, children, and migrant Dominican and foreign labor. The available labor pool for coffee production and (especially) harvest has been influenced by out-migration to urban centers, especially by younger male adults.

Haitian labor has become the norm for hired labor, particularly, for clearing coffee fields and for harvest. In some areas of the country, Haitian migrants provide more than $90 \%$ of coffee harvest labor. Dependency on Haitian labor has been a source of periodic tension and conflict in some rural areas. An estimated 50,000 to 70,000 part-time workers participate in coffee production and harvest. It is estimated that some 30,000-50,000 Haitians move from one region to another working for periods of two to three months in harvesting coffee. ${ }^{37}$

Producers and other sources frequently cited access to adequate (low-cost) labor as an increasing problem for the coffee sector, especially harvest labor. Inadequate supplies of harvest labor may constrain movement toward increased farm sizes and increased productivity on renovated or replanted coffee plantations. While some labor-saving technologies may emerge over time, innovative means of identifying and contracting harvest labor may provide a solution to current and future labor shortages in the sector. ${ }^{38}$

\section{Finance}

Direct credit for coffee producers has been limited over the years, and this continues to be the case. Long-term formal credit is limited in the Dominican Republic agricultural sector in general. Short-term and informal credit (from exporters, intermediaries, moneylenders, etc.) for coffee

\footnotetext{
${ }^{36}$ The CRMG survey found that nearly $25 \%$ of families on the smallest farms received income from working on another coffee farm. Some larger-scale producers also received coffee income off the farm, with about $14 \%$ of the $>10$ hectare class reporting coffee income from other's farms.

${ }^{37}$ Migration International (2002) gives the lower estimates and other sources give the higher estimates.

${ }^{38}$ There are examples of contracting foreign migrant labor, such as some of the contracts that US farmers have to provide seasonal work for migrant agricultural laborers. Importantly, these contracts are also supposed to protect the rights of laborers, which is also an important issue in DR.
} 
production exists, but data are not available for these types of transactions. Exporters and intermediaries sometimes agree that a farmer's coffee trees are adequate collateral to guarantee short-term production loans. Interest rates vary widely. Some coffee producer associations and cooperatives have tried over the years to provide credit, but this has not been widespread nor have these institutions been sustainable sources of financial services.

The CRMG survey showed that only $20 \%$ of the largest and medium-sized coffee producers received production credit, compared to around $13 \%$ of the smallest-scale producers. An econometric analysis (using CRMG survey data) of credit uptake by coffee producers found that producers who received a large share of farm income from coffee (i.e., they were more specialized in coffee production) and those that belong to producer associations were most likely to receive loans. Land holding size and household head's education were not significant determinants of credit uptake (CRMG, 2003). These results suggest that membership in a producer association may be an effective way of promoting more short-term credit among coffee producers. ${ }^{39}$ Also of interest was the result that surveyed coffee producers who claimed that weather related risks were very important were more likely to obtain credit.

\section{Environmental impacts of coffee}

Coffee production can play an important positive role in the protection of natural resources in Dominican Republic, especially plantings located at the head of the major watershed and main rivers in the country. Coffee plantations are located in the highest zones of the main mountain ranges in the country, in areas where the cloudy tropical rainforest dominate. These areas are critical for sustaining rivers and water quality in general, and susceptible to soil erosion if not properly managed.

Hwang (1992) found that in Central Dominican Republic, continuous coffee cultivation was associated with soil loss rates of $27 \%$ and $7 \%$ compared to traditional maize on $12 \%$ and $28 \%$ slopes. Substantial on-farm productivity effects from soil conservation together with the external costs associated with water quality and dam maintenance indicated that more widespread coffee production was a least-cost means of achieving improved environmental quality.

When coffee is produced using an integrated system of coffee and shade trees, soil erosion is reduced. ${ }^{40}$ Organic production technologies can further limit problems related to agri-chemical run-off. Trends towards more input-intensive coffee production systems with fewer shade trees and higher rates of fertilization and chemical applications are less consistent with improved environmental quality. There is a need to monitor these changes and design programs and projects that provide incentives for more environmentally benign and/or beneficial coffee production systems.

Wet processing can, however, have negative environmental impacts (Varangis, Siegel, Giovannuci, Lewin, 2003). Wet milling requires large amounts of water (about 200-500 liters to produce $46 \mathrm{~kg}$ of green beans). The process is the same whether it takes place in big mills or by individual coffee farmers. Given the large amounts of water used, mills tend to be situated near rivers. Water used in milling is highly contaminating, containing sugar from the pulp and residuals from the fermentation. Discharging the water directly in the stream or river pollutes the

\footnotetext{
${ }^{39}$ In fact, access to credit (and especially subsidized credit) has historically been a major motive for producers joining associations and cooperatives.

${ }^{40}$ See Varangis, Siegel, Giovannuci, Lewin (2003) Chapter IX, pages 54-63 for an overview and references on environmental aspects of coffee production
} 
water, destroying aquatic flora and fauna, and contaminating drinking sources. During harvest, the individual farmer re-uses water to speed up the fermentation process of the next lot. However, recycled fermentation water can affect coffee quality.

\section{Wet Processing: Potential for Environmental and Economic Benefits}

A new project proposed by ICP (see EDE, 2002) for a coffee producer association suggests that instead of carrying out on-farm wet processing and delivering wet parchment to processing centres, producers should take ripe cherries to centralized wet processing stations to be installed at strategic locations. Producers living far from processing stations would continue to depulp coffee individually and deliver wet parchment. The report notes that coffee that is individually wet processed should be separated as mixing with central facility wet-processed coffee might compromise quality. Essential components in washed coffee processing will be dry pulping, mechanical transport of cherries, coffee beans and pulp, mechanical mucilage removal as well as recycling of water. There will be no direct discharge of water into rivers. Only treated waters will be injected into rivers and minimum levels of BOD and COD will be assured. Decomposed pulp will be used as organic fertiliser.

\section{E. Structure of Post-Harvest Activities, Marketing and Exports}

The chain of post-harvest activities begins on the coffee farms and includes other actors, such as intermediaries, exporters, and domestic processors.

\section{E.1 Post-Harvest Practices}

Coffee requires rapid processing. Coffee producers often carry out some post-harvest activities and participate in the first phase of sale of the coffee. Picking is usually selective, limited to berries as they ripen, meaning that the typical farm requires three pickings per season. The berries are pulped the same day by mechanical depulpers and fermented, washed and sun-dried. The practice of individual picking and of wet processing, when done "correctly" can result in high quality coffee. However, when carried out "incorrectly," it can cause considerable damage to coffee quality and also lower the quantity of marketable coffee. ${ }^{41}$

Improvement of post-harvest activities by producers and associations has long been a priority of GoDR, including the World Bank Cocoa and Coffee Project in the 1980s. It is currently a major priority of programs and projects funded by the French Development Agency, USAID and International Coffee Partners (more details are provided later). A major constraint to improving post-harvest practices has been the lack of pricing incentives paid to producers; the marketing system has not historically rewarded high-quality coffee.

Besides on-farm wet milling, a number of small and medium scale commercial wet processing facilities exist. Many of these are marginal, poorly maintained operations. Approximately 140 small factories exist around the country; nearly 30 of these are operated by associations and federations of producers. The industry has undergone increasing concentration in fewer, larger enterprises. Large milling enterprises use sun and mechanical drying. Large mills are currently underutilized due to stagnant coffee production and competition from smaller milling enterprises. The main exporting firms operate the larger plants. Most of the larger coffee milling facilities are located in valleys around Cibao.

\footnotetext{
${ }^{41}$ See Varangis (1989, p.7), for an explanation of how inappropriate post-harvest practices negatively impact both the quality and quantity of marketable coffee.
} 


\section{E.2 Coffee Intermediaries}

When producers wet mill coffee on their farms, they sell it by the box to intermediaries.

Producers sell their coffee to intermediaries, exporter agents, or producer associations, usually for cash at the "going market price". The CRMG survey indicated that $72 \%$ of coffee producers sell their coffee to "intermediaries".

In the case of exporter agents and local intermediaries, purchase occurs either on farm or at local buying centers. From the CRMG survey, 75\%, of coffee producers claimed to know the local price of coffee while the less then $30 \%$ of producers claimed to know the international price. This lack of information about the international price was uniform across farm size with larger producers having slightly more international price knowledge. Results indicated that local prices were mainly conveyed through friends and intermediaries whereas international prices were communicated by radio and television. Smaller producers relied more heavily on intermediaries for knowledge about the price. The situation is similar for cocoa producers.

Intermediaries buy coffee from the producers and other intermediaries in order to resell it to an exporter or tower processor. Three general types of intermediaries can be identified:

1. Intermediary with factory: purchases moist coffee, prepares the green coffee, and sells it to exporters and to processors.

2. Warehousing intermediary: local merchant who buys moist coffee, collects volumes and sells them to the factories. Generally takes advantage of the needs of the small producers and transports volumes of coffee from the local communities to the factories.

3. Broker intermediary: purchases coffee by moving from one community to another, generally acting as purchasing agent for intermediaries with factories or exporters.

The CRMG survey showed that less than $20 \%$ of producers sell coffee directly to exporters, and less than $35 \%$ were members of producer associations. Larger scale producers were more likely to sell directly to exporters and are also more likely to be members of producer associations.

\section{E.3 Coffee Exporters}

Exporters purchase moist and parchment coffee, process the green coffee, and prepare it for export. They are generally intermediaries with factories, with finance to purchase coffee. They also purchase coffee from other intermediaries and sell non-exportable coffee to processors. Some exporters own and run large coffee plantations; many also export cocoa.

Several types of coffee exporters are found: a) "traditional" commercial exporters , b) "other" commercial exporters, c) exporter producers, and d) producer associations (see table III.10). A small number of traditional commercial exporters export about $70-80 \%$ of Dominican coffee, and "other" commercial exporters export another 10-20\%. Export and producer associations only account for about $3-10 \%$ of coffee exports. Coffee export is thus concentrated in the hands of a few large commercial operations.

The Dominican coffee sector has a number of associations, cooperatives, and other organizations, but few undertake direct marketing or financing. Producer organizations exist more as units of organization and help create links between producers and other actors in the market such as NGOs, donors, cooperatives, and the public sector. These organizations generally do not provide export and marketing services. Coffee producer organizations were once stronger and more 
active in marketing, particularly in the early 1990 s, but of late many have been in decline. ${ }^{42}$ Results of the CRMG survey indicate that only $22 \%$ of the producers were members of producer organizations.

In 1990, about 20 producer associations were registered as exporters and up until 1996 they accounted for about 20\% of Dominican Republic's coffee exports. Between 1993 and 1999, these organizations experienced a decline in export share from $9.4 \%$ to $2.2 \%$ of coffee exports. Problems associated with the recent sharp international price decline have caused many of these associations to become heavily indebted. Of the associations that exported in the early to mid 1990 s, fewer than half have exported regularly in recent years. ${ }^{43}$ For example, Café La Joya, which was the leader in quality coffee exports, has lately had trouble finding financing for its coffee.

\section{INDUBAN (Industrias Banilejas C. Por A.)}

The internal coffee market is controlled by INDUBAN, who functions as a local buyer, exporter, and roaster of coffee. INDUBAN controls about $95 \%$ of the domestic market and about $20-30 \%$ of exports. Recently, in May 2003, INDUBAN has not been exporting coffee due to narrow profit margins; especially compared to domestic markets. INDUBAN purchases most of its coffee at regional buying centers and either roasts it and sells it into the internal market or sells green coffee for export. Historically, INDUBAN paid producers the international market price minus a predetermined marketing margin. This price was communicated on a regular basis to INDUBAN's local buyers. Recently, however, due to low international prices, the company lists a price that remains constant for many months, and instructs its buyers and managers to use this price as a base for a standard "good quality" price. In practice, the buyers often pay prices below this listed price. INDUBAN's management indicates that at least $25 \%$ of its purchases are below the standard "good quality" price.

\section{Major Producer Associations and Cooperatives}

Coffee producer associations are generally small with limited functions and services. There are, however, some important coffee producer associations.

FEDECARES is made up of ten nuclei (associations) which aggregate smaller associations throughout the Southwest. FEDECARES encompasses 6,000 farmers on 15,625 hectares who produce on average between 80,000-85,000 qq annually (for an average of 2.6 ha/producer and average yield of $250 \mathrm{~kg} / \mathrm{ha}$ ). FEDECARES has been participating with CODOCAFE in a major coffee rehabilitation project following damage from Hurricane Georges. This program also replaces trees affected by disease and age, and has benefited 2,472 families and 772 hectares. $^{44}$ FEDECARES provides some production credit to its members. The typical term involves a twoyear repayment schedule. ICP is working with FEDECARES on its coffee project.

Union de Asociaciones de Caficultores del Norte, Inc (UNACAFEN) is a non-profit apex farmers association established in 1991 that works to aggregate associations and producers organizations throughout the central and northern mountains. This cooperative provides commercialization and

\footnotetext{
${ }^{42}$ The proliferation of producer associations can be attributed to SEA's long-standing efforts to organize small coffee producers. These efforts help explain the lack of clearly defined functions for these groups.

${ }^{43}$ SOFRECO (2002, p.31).

44 "Caficultores del Sur ven la luz al final del túnel”, Listin Diario, November, 29, 2001.

44“"La caficultura espera la mano del Gobierno”, Listin Diario, October 18, 2001.
} 
capacity building services to its members. As an apex body, UNACAFEN is an umbrella organization for 17 smaller associations. UNACAFEN is governed by a general assembly of 10 delegates from every member association, and three representatives from UNACAFEN are represented in CODOCAFE. Member associations can sell or export coffee on their own or sell to UNACAFEN for export. UNACAFEN typically pays a slightly higher price than other exporters but because the price is not paid in full upon delivery, its popularity as an export agent is limited.

Table III.10: Major Coffee Exporters 1993-1999

\begin{tabular}{|c|c|c|c|c|c|c|}
\hline Type of Exporter & $1993 / 94$ & $1994 / 95$ & $1995 / 96$ & $1996 / 97$ & $1997 / 98$ & $1998 / 99$ \\
\hline \multicolumn{7}{|l|}{ 1. Traditional Exporters } \\
\hline 1.1. Induban Group & $51,905.31$ & $123,640.06$ & $115,408.71$ & $89,943.55$ & $71,064.77$ & $36,845.51$ \\
\hline$\%$ National Exports & $14 \%$ & $23 \%$ & $17 \%$ & $23 \%$ & $13 \%$ & $17 \%$ \\
\hline \multicolumn{7}{|l|}{ 1.2. Cibao Groups } \\
\hline Total of the Cibao Group & $150,439.17$ & $248,981.47$ & 271,228.17 & $164,109.66$ & $292,501.70$ & $68,559.30$ \\
\hline$\%$ National Exports & $42 \%$ & $46 \%$ & $39 \%$ & $42 \%$ & $53 \%$ & $32 \%$ \\
\hline \multicolumn{7}{|l|}{ 1.3. Barahona Group } \\
\hline Total Barahona Group & $52,052.26$ & $56,886.93$ & $140,209.26$ & $34,720.79$ & $120,114.88$ & $53,411.40$ \\
\hline$\%$ National Exports & 0.14 & 0.11 & 0.20 & 0.09 & 0.22 & 0.25 \\
\hline 1.4 Total Traditional Exporters & $254,396.74$ & $429,508.46$ & $526,846.14$ & $288,774.00$ & $483,681.35$ & $158,816.21$ \\
\hline$\%$ National Exports & $70 \%$ & $80 \%$ & $76 \%$ & $73 \%$ & $87 \%$ & $74 \%$ \\
\hline 2. Other Exporters & $67,542.00$ & $72,821.76$ & $133,580.57$ & $94,370.38$ & $54,698.15$ & $39,977.31$ \\
\hline$\%$ National Exports & $19 \%$ & $14 \%$ & $19 \%$ & $24 \%$ & $10 \%$ & $19 \%$ \\
\hline 3. Exporter Producers & $6,134.31$ & $5,373.71$ & $5,677.95$ & $1,615.41$ & $2,480.18$ & $7,440.53$ \\
\hline$\%$ National Exports & $1.7 \%$ & $1.0 \%$ & $0.8 \%$ & $0.4 \%$ & $0.4 \%$ & $3.5 \%$ \\
\hline \multicolumn{7}{|l|}{ 4. Producer Associations } \\
\hline Fedecares and Asoc. & $11,326.13$ & $8,267.25$ & $5,787.08$ & $3,306.90$ & $6,198.78$ & 826.73 \\
\hline Asoc. De Villa Trina & $10,747.43$ & $13,640.96$ & $11,160.79$ & $1,240.09$ & 793.66 & 77.71 \\
\hline Various Other Associative Groups & $11,988.87$ & $6,674.98$ & $7,961.38$ & $4,563.53$ & $5,181.91$ & $6,271.79$ \\
\hline Total Producer Associations & $34,062.43$ & $28,583.19$ & $24,909.25$ & $9,110.52$ & $12,174.35$ & $7,176.23$ \\
\hline$\%$ National Exports & $9.4 \%$ & $5.3 \%$ & $3.6 \%$ & $2.3 \%$ & $2.2 \%$ & $3.4 \%$ \\
\hline GENERAL TOTAL & $362,135.48$ & $536,287.12$ & 691,013.91 & $393,870.31$ & $553,034.03$ & $213,410.28$ \\
\hline
\end{tabular}

Source:SEA; Statistics section, Division of Special Studies,"CODOCAFE".

\section{E.4 Domestic Coffee Market}

The domestic coffee market traditionally commands an important share of national production. Roasters buy green coffee, roast, grind and sell it on local markets with different brands and forms of presentation. The domestic processing industry is more highly concentrated than the export market; one company - INDUBAN - accounts for over $95 \%$ of domestic coffee processing.

A major question is the extent to which INDUBAN's commanding market share affects market efficiency. Scale economies may favor large-scale domestic coffee marketing. However, important questions need to be addressed about how INDUBAN's domination in the coffee sector affects producers' choices of production and post-harvest technologies. For example, since 
INDUBAN has a guaranteed domestic market for coffee that is not "export quality," it has traditionally paid a single price to coffee producers without relation to coffee quality. This policy has served as a disincentive to improve coffee quality and on-farm post-harvest practices.

It is interesting to note that previous World Bank reports (e.g., World Bank, 1981; 1991; Varangis, 1989; World Bank, 2002a) all acknowledged the possibility that excessive market power and resulting inefficiencies "might" possibly exist in the coffee sector, but found no concrete evidence of inefficiency. These reports, however, argue that the pricing system does not reward quality and the lack of quality incentives constrains quality and price improvements for producers. A rigorous analysis of INDUBAN's domination of the Dominican coffee sector is needed to examine the existence or absence of market inefficiencies, and impacts on the sector.

\section{E.5. Estimates of Marketing Margins}

Attempts to try and generalize marketing margins are difficult because of the difficulty to obtain accurate and consistent data from all those involved in the marketing chain. Marketing margins are important for analyzing market efficiency and international competitiveness. We present indicative calculations of marketing margins based on several sources.

On May 29, 2003 the NYBOT price for "other milds" was \$65/qq, and the price differential for Dominican coffee was minus 400 points $^{45}$. Thus, the NYBOT reference price for Dominican coffee was $\$ 61 / \mathrm{qq}$. The estimated FOB price for Dominican coffee is about $\$ 6 / \mathrm{qq}$ less (for broker and freight charges). Based on several sources, the domestic marketing margins from farmgate to port were estimated to be about $\$ 15-18 / \mathrm{qq}$. Thus, the total difference between the NYBOT price for "other milds" to the farmgate price were estimated to be about $\$ 25-28 / \mathrm{qq}$, for a farmgate price of $\$ 37-40 / q q$. At the same time INDUBAN was paying farmers RD $\$ 1500 / q q$ as its "standard" price for coffee ${ }^{46}$, or about \$55/qq (which includes the GoDR RD\$200/qq support price). Thus, there is presently no clear relationship between NYBOT prices and farmgate prices.

\section{F. Other Coffee-related Institutions}

Coffee institutions include public and private sector actors who regulate, support and participate in the industries. The public sector in the Dominican Republic has undergone significant restructuring in recent years as a result of budgetary pressures and efforts to improve efficiency. The biggest impact of this restructuring on the coffee sector is to increase the administrative autonomy of government institutions serving the coffee sector. The private sector is comprised of for-profit enterprises and cooperatives and non-governmental organizations that provide a mix of public and private functions. The main institutional functions include provision of research and technical assistance, collection and dissemination of data and information, regulation of input and output markets, provision of services including marketing and export and establishment of an overarching policy environment.

This section provides an overview of public and public-private institutions, international agencies and NGOs involved in the coffee sector.

\footnotetext{
${ }^{45}$ In contrast, coffee from Mexico, El Salvador, Guatemala, Costa Rica, Nicaragua and Panama were all receiving the basis, and Honduras was receiving minus 100 points and Columbia plus 200 points.

${ }^{46}$ Although the "standard" price is RD $\$ 1500 / \mathrm{qq}$, INDUBAN discounts this price for producers delivering low quality coffee. About $25 \%$ of coffee has its price discounted. With relatively low prices in recent years, INDUBAN indicated that the proportion of producers delivering low quality coffee has been increasing.
} 


\section{F.1 Government}

CODOCAFE (see Section I.D.3) is the only public institution dedicated exclusively to coffee, but other public institutions support the industry. These include SEA, who provides technical assistance for non-coffee crops to coffee producers, the national agricultural research institute (IDIAF), the Secretariat of Natural Resources and the Environment, Banco Agricola and the Institute for Agrarian Development (IAD). Formation of CODOCAFE followed a long period of relatively ineffective support by government for the coffee sector via the Coffee Department and Coffee Commission.

Through the 1980s, the Dominican government was heavily involved in programs to rehabilitate and modernize the coffee sector. Some of these programs were responses to natural disasters such as hurricanes; some were in recognition that long-term taxation had left the sector in dire conditions. Financing for these programs came from international donors and government funds. These programs were only marginally successful, and in 1986, the Presidency intervened with a major program to rehabilitate and replant coffee plantations. The thrust of the program was support to small-scale (less than 6.2 hectares) producers in renovation and replacement of older varieties with higher-producing caturra varieties. This program, executed by the Departament of Coffee (DC) in the Secretaria de Estado de Agricultura (SEA), was hampered by poor performance and failed to meet its targets.

The programs left the DC with about 40 greenhouses for the production of coffee seedlings. These greenhouses are the largest source of coffee seedlings in the country and have the capacity to produce about 4 million seedlings per year. Government subsidizes the sale of seedlings ${ }^{47}$. The DC (and now CODOCAFE) has been slowly disengaging from the "nursery business," and is coordinating seedling production with the private sector by providing inputs and technical assistance to sanctioned nurseries (some of which are managed by producers associations and cooperatives). Currently, more than 88 of these seedling facilities exist, some operated by CODOCAFE and others by private institutions. Of note is the fact that CODOCAFE has recently begun producing and distributing tipica plants. In addition, to support efforts toward diversification into fruits, these greenhouses have produced and distributed more than 170,000 fruit seedlings.

Creation of CODOCAFE removed administrative responsibility for the coffee sector from SEA (and the Department of Coffee). CODOCAFE is an autonomous public institution ${ }^{48}$. Its decision making power lies with its 19 member board made up of government officials, representatives from producer organizations, exporters, and representatives from industry associations (SEA officially chairs CODOCAFE).

CODOCAFE provides technical assistance and extension services to producers in 176 coffeegrowing areas. Producers are arranged in "nuclei" or small groups of 6-12; each of these groups benefits from a 21 day visitation cycle of a team of local "extension agents" from one of 27 extension offices located in coffee-growing areas. CODOCAFE reports that more than 4,000 such nuclei have been created with more than 28,000 members. According to the French Development Agency, the highly decentralized nature of these extension services makes quality control in their delivery difficult.

\footnotetext{
${ }^{47}$ It is estimated that costs of production are RD $\$ 3.75$, while the seedlings are sold at RD 1 .

${ }^{48}$ CODOCAFE's annual budgets were, not including foreign assistance and a one-time capitalization in 2001: 2001- RD\$109 million; 2002 - RD\$ 219 million; 2003 - RD\$ 216 million.
} 
CODOCAFE coordinates coffee-related research conducted by IDIAF. It coordinated research into broca control and subsequently multiplied and distributed the biological control agents that form the core of the broca strategy. Other research thrusts include a USAID-supported geographical information system project, and research into diversification and technology adoption.

CODOCAFE currently has several initiatives. These initiatives rely heavily on donor support for funding and for technical assistance: a) rehabilitation of 37,500 ha (600,000 tareas) of coffee to increase productivity and overall production, $b$ ) continue with program against the broca coffee pest, c) support by CODOCAFE to produce 100,000 coffee plants, provide technical assistance, establish demonstration plots, carry out research on new technologies, and rehabilitate $500 \mathrm{~km}$ of roads in coffee producing areas, and d) proceed with new French-funded (by a loan from the French Development Agency) project aimed at improving coffee productivity and quality, postharvest technologies, and efforts to capture premiums for good quality coffee.

The export compensation fund, created by Decree No. 1045-01, is administered by CODOCAFE. This fund is intended to preserve coffee cultivation in the Dominican Republic in the face of the coffee crisis and compensates marketing agents in the amount of RD\$200 per hundredweight of exportable coffee. It received an initial budget of $\mathrm{RD} \$ 140$, and is supposed to be in effect until international coffee prices reach US\$100/qq. These funds are intended to compensate producers for low coffee prices, but it is unclear how much of the money actually reaches its intended recipients.

\section{F.2 International Development Agencies and NGOs}

A number of major international development agencies conduct programs in support of the Dominican coffee sector. This interest is due to the environmental significance of coffee to watershed management in the Dominican Republic, and a response to recent world coffee price declines and their perceived negative impacts on producers and laborers.

\section{French Development Agency ${ }^{49}$ (Agence Francaise de Developpement)}

The foremost among these projects is a coffee improvement program sponsored by the Agence Française Développement in conjunction with CODOCAFE. The project, "Improving the Quality of Dominican Coffee and Promoting Specialty Coffee" was approved March 19, 2002 by the House of Representatives and is worth about 24 million euros, 17 million of which will be provided as a long-term concessionary loan by the French Government. This program is aimed at improving the quality of Dominican coffee and creating a number of specialty coffees. Two other goals of the project are to increase the demand for Dominican coffee worldwide and distribution the benefits of coffee production across a larger number of producers. To accomplish these goals the project will aim to increase the export of specialty coffee from $1 \%$ to $10 \%$ as well as improve the overall quality of non-specialty Dominican coffee. Producer organizations were required to become members of a newly formed apex organization for the sector ADOCAFES. ADOCAFES will serve as the pass through organization for the French activities but will also be established as the Dominican Specialty Coffee Association. Work with producer organizations will be oriented towards enabling them to export their own coffee directly into the international market and

\footnotetext{
49 "Nota de Prensa", "El Proyecto de "Mejoramiento de la calidad del cafe dominicano y promocion de cafés especiales".
} 
strengthening organizations to aggregate sufficient demand and quality so that they can compete with private exporters.

\section{USAID}

USAID has several initiatives in the coffee sector: a) the Central America Regional Specialty Coffee Program for 5 countries in Central America and the Dominican Republic -- focusing on improving quality and access to specialty coffee markets; b) continuation of the broca control program (this US\$23 million dollar program was jointly funded by USAID--US\$14 million-- and GTZ -- US\$9 million); and, c) continuation of activities originally funded as part USAID assistance for recovery from Hurricane Georges. The latter program includes activities such increasing the productivity of agricultural producers through the diversification of fruit trees, quality control, broca control, and technology transfer assistance. ${ }^{50}$

\section{International Coffee Partners (ICP)}

The International Coffee Partners (ICP), a consortium of four European coffee roasters and a major coffee trader, have combined to support development projects in coffee growing countries. In the Dominican Republic they have begun a project to work on a spectrum of quality and marketing activities with an individual cooperative, FEDECARES. The program includes intensive training and technical assistance for this cooperative on how to improve each step in their supply chain, and also includes components that address issues of income diversification and environmental management. This is a more holistic approach to coffee production and producers than usually practiced (see EDE, 2002).

\section{Fundocafe}

Fundacion Dominicana para el Desarrollo del Café de Calidad Inc (Fundocafe) is a privately funded local NGO created in 1995 to identify and promote the highest quality coffees grown in the Dominican Republic. This organization undertakes a variety of activities aimed at improving coffee quality. Fundocafe is engaged in activities such as capacity building, extension, and technical assistance. It has a unique program which exports specialty and organic coffee "door to door" in quantities as small as $25 \mathrm{lbs}$. It has also established a revolving loan fund and improved access to inputs for farmers.

\section{G. Competitiveness of the Dominican Coffee Sector}

Any rigorous quantitative analysis of the sector is made difficult by the nature of coffee (and cocoa) production and marketing. Government policy affects everything from input prices and labor costs to the cost of capital and market structures. The latter two are particularly important for perennials, and without a comprehensive review of these policies and their impacts an assessment of competitiveness is difficult. Coffee production is characterized by heterogenous technologies and input uses, yields vary dramatically according to market conditions and intensity of management. Furthermore, many of the official crop budgets (e.g., from SEA, Banco Agricola, CODOCAFE, Department of Cacao) have been prepared with a focus on obtaining government support for producers and costs have seemingly been inflated. The authors examined many of these budgets while trying to measure competitiveness and found too many

${ }^{50}$ www.usaid.gov 
inconsistencies to reconcile. Trying to generate representative "crop budgets" that are meaningful, based on existing data, is no easy task ${ }^{51}$.

These problems are multiplied if we want to compare crop budgets among different countries, where many of these same issues are also relevant. A common practice is to simply compare average yields among countries, or more actually simply dividing total national production by estimated land area and assuming this number reflects the "average yields". The authors suggest production of systematic household-level budgets that include all income generating activities, based on statistically valid data collection techniques. Such processes would help understand the economics of coffee and cocoa production for purposes of future analyses and planning.

Studies of economic competitiveness also do not reflect the utility of the commodity within typical systems of household production. Coffee production occupies an important role within the livelihood system of smallholder households. It is an informal substitute for formal titles to land; continuous coffee cultivation is a powerful means of maintaining possession of farmland. Many credit providers view possession of coffee plantations as adequate collateral for even longterm loans. Coffee helps the household manage cash and labor flows and serves as an income reserve. As such, it helps producing households overcome serious imperfections in rural factor markets. Coffee also gives a household a claim on "emergency relief" that generally follow natural disasters such as hurricanes. All of these factors are internal to the household and create conditions whereby a conventional measure of competitiveness will underestimate the value of production to the household.

The three things that we do know about the Dominican coffee sectors, are: a) there are areas where growing conditions are considered to be among the best in the world, b) Dominican coffee and cocoa producers are known for their poor post-harvest practices and low quality beans which result in price discounts in international markets, and c) hurricanes have caused periodic damage to yields and affect the stability of production and the ability to be a dependable supplier. The Dominican coffee sector is facing two crises: an external one, suffered by all major producers in the world, and an internal one. These crises compound each other and affect future prospects of the industry. The industry still faces a number of structural barriers that limit its prospects. These include taking advantage of its natural resource base to achieve productive competitiveness, problems in the marketing system whereby quality is not rewarded, and other marketing inefficiencies.

Concerns about improved competitiveness include mixed varieties in coffee stands, little quality selection exercised during harvest and little quality control during the on-farm wet milling process. Marketers do not differentiate product by coffee quality. Recently, international markets have recognized the quality problem leading to negative price differentials for Dominican coffee. The largest coffee buyer, INDUBAN, has a "one price" policy that discourages farmers from improving quality. Also, there are no national quality standards for coffee. The focus of the sector is moving toward improvements in quality and donor resources have been flowing into this area. COCOCAFE has recently been considering the formulation and implementation of national coffee quality standards. Such a coffee quality control program at the national level should complement efforts by donors and NGOs aimed at enhancing quality. Clearly, the marketing system would need to provide differential pricing based on quality to make such a system effective in rewarding quality.

\footnotetext{
${ }^{51}$ The authors were also unable to locate reliable information on yield responses to fertilizer application for coffee or cocoa.
} 
Coffee productivity has seemingly not increased substantially in the Dominican Republic despite years of efforts to shift to higher yielding varieties, and a slow shakeout of smaller-scale producers (figure III.1). Average yields in the Dominican Republic are below other coffeeproducing countries in the region and appear to be trending downward. ${ }^{52}$ These trends do not portend well for the competitiveness of the Dominican coffee sector. Low productivity is compounded by increasing costs of production, particularly labor costs and high financing costs.

Figure III.1 Coffee yields, Dominican Republic and various countries, 1970-2002

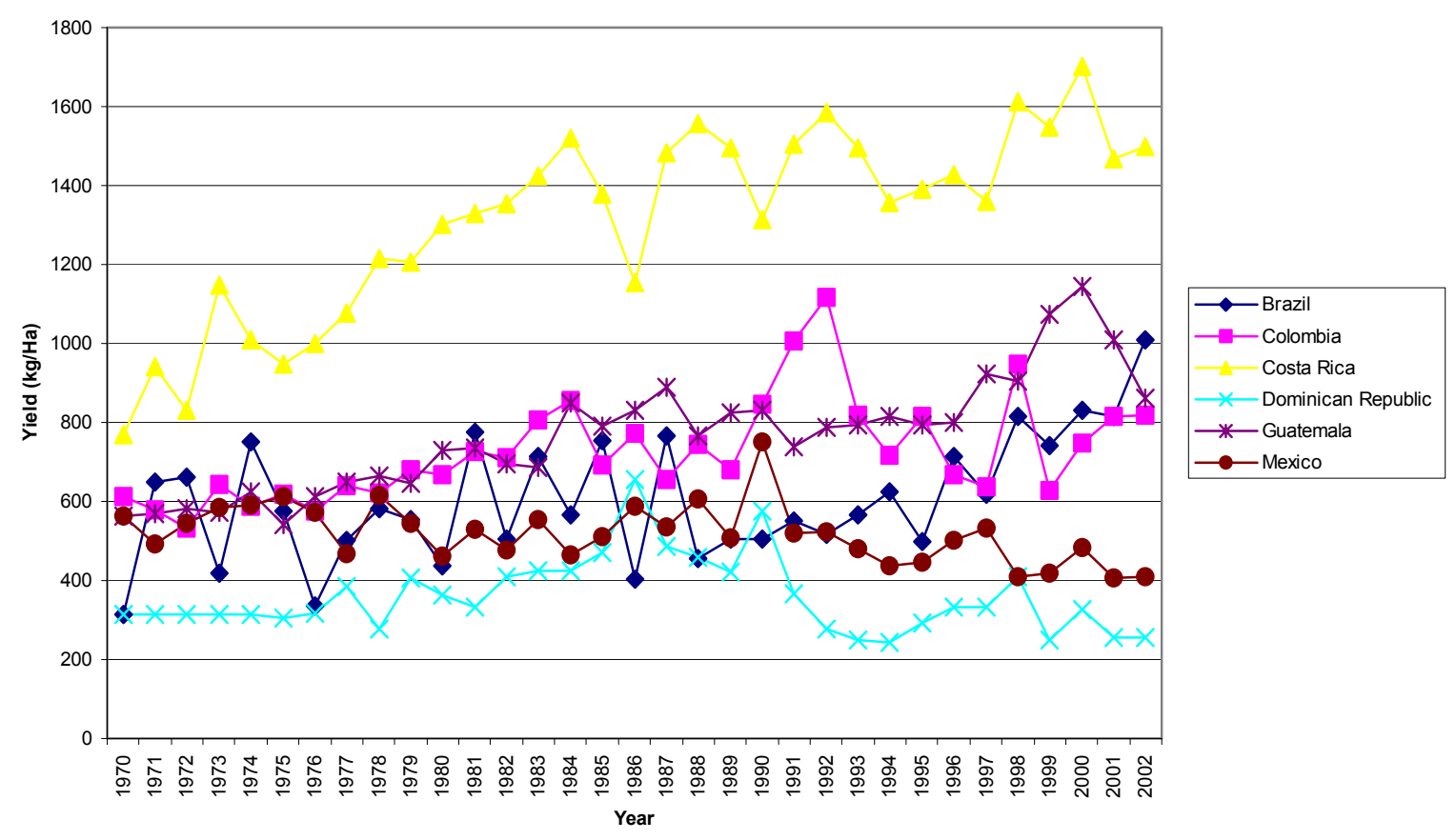

Source: FAO Statistical Database

Several representative budgets were examined in an effort to measure the costs of coffee production. Estimated costs range from US\$45-85 per hundredweight ${ }^{53}$, depending on technology use and yields. As noted above, these estimates are subject to a number of caveats, but compare favorably to estimates from other sources in other countries in the region (table III.11). Low yields, high production costs and poor quality beans are the main constraints to the competitiveness of the Dominican coffee sector.

\footnotetext{
${ }^{52}$ A recent diagnostic carried out for FEDECARES indicates that average yields of its 3,500 members are about $80 \mathrm{lbs} /$ tarea. (or $550 \mathrm{~kg} / \mathrm{ha}$ ).

${ }^{53}$ A recent study carried out for COCOCAFE (see Mercedes, 2002), indicates higher costs of production than returns from coffee sales for low, medium and high technified coffee producers, although high technified producers have a lower cost of production per qq and receive a higher price per qq.
} 
Table III.11 Coffee Costs of Production in Central American Countries

\begin{tabular}{|l|l|c|c|c|}
\hline & & Consultants & CEPAL & LMC \\
\hline & & US\$/quintal & US\$/quintal & US\$/quintal \\
\hline Guatemala & & 51 & 74 & 74 \\
\hline Eosta Rica & & 77 & 86 & 100 \\
\hline Nicaragua & & 48 & 57 & 84 \\
\hline & Traditional & 53 & 70 & 67 \\
& Semi-technified & 58 & & \\
& Technified & 70 & & \\
\hline Honduras & & & 62 & \\
\hline & Traditional & 36 & & \\
& Semi-technified & 46 & & \\
& Technified & 58 & & \\
& & & & \\
\hline
\end{tabular}

Source: The sources of data for this table are explained in Varangis, Siegel, Giovannuci, Lewin (2003, p.12). 


\section{Overview of the Dominican Cocoa Sector}

An overview of the cocoa sector in Dominican Republic is presented in this section. As described in the beginning of section III on the coffee sector, various data and information sources were used, including a CRMG survey of cocoa producers carried out in mid-2002.

\section{A. Overall Trends in Cocoa Production}

The Dominican cocoa industry first emerged in the 1880s as an alternative smallholder crop to tobacco, which was experiencing steep price declines. Growing conditions in the Dominican Republic were found to be favorable for cocoa. Although long overshadowed by coffee, cocoa production has expanded significantly since the 1970s, and recent trends indicate that cocoa is overtaking coffee in terms of producers, land area, and value of production and exports.

The land area planted with cacao trees increased from 65,000 hectares in 1971 to 115,000 hectares by 1980, and by 1987, approximately 40,000 MT of cocoa were produced on 134,000 hectares. During the 1990s, the Dominican cocoa sector achieved parity with, and in some years surpassed coffee sector in terms of its contribution to GDP and exports. Despite recent growth, Dominican cocoa producers traditionally have been characterized as having relatively low yields and low quality post-harvest product. The cocoa sector is similar, in this sense, to the coffee sector with problems related to quality. On the other hand, the cocoa production and exports are increasing, while coffee production and exports are in decline.

Like coffee production, cocoa production is vulnerable to damage from hurricanes. Cocoa production reached its peak from 1994 to 1998, averaging about 63,000 MT/year, but fell to about 26,000 MT in 1998/9 as a result of Hurricane Georges (see table IV.1). The cocoa sector subsequently recovered, and production reached about 45,000 MT in 2001/2. After Hurricane Georges, many cocoa plantations were rehabilitated and replanted, most with improved varieties. In fact, Hurricane Georges and high international cocoa prices has provided the sector an opportunity to introduce major changes, some of which have been made. As cocoa trees require up to six years to reach their full production potential, the post-Georges recovery in production has not yet been fully felt.

The CRMG survey indicated that about $60 \%$ of cocoa producers planted new cocoa trees in the past 5 years. Interestingly, producers with 5-10 ha were more likely to plant new cocoa trees (about 64\%) and remove cocoa trees (about 21\%) than smaller-scale (less than 5 hectares) and medium-scale (5-10 hectares). The high proportion of producers with new plantings indicates that good possibility for increased production in the near future.

Table IV.1 Cocoa Land Area and Production 1990/1 - 2000/1

\begin{tabular}{|c|c|c|c|c|c|c|c|c|c|c|}
\hline & $1990 / 1$ & $1991 / 2$ & $1993 / 4$ & $1995 / 6$ & $1996 / 7$ & $1997 / 8$ & $1998 / 9$ & $1999 / 00$ & $2000 / 1$ & $2001 / 2$ \\
\hline Area- 000 ha & 121 & 121 & 127 & 137 & 142 & 153 & 109 & 139 & 126 & 125 \\
\hline Production- MT & 43,157 & 51,210 & 63,960 & 61,937 & 52,442 & 69,727 & 25,861 & 37,107 & 44,908 & 45,468 \\
\hline Avg. Yield/ha & 0.28 & 0.42 & 0.50 & 0.45 & 0.37 & 0.46 & 0.24 & 0.27 & 0.36 & 0.36 \\
\hline
\end{tabular}

Source : Cocoa Department Statistics (note: 1990/1 crop is the harvest year 1991).

High international cocoa prices in recent years combined with the sharp coffee price and production decline have created conditions under which the Dominican cocoa sector is overtaking the coffee sector in economic importance. The cocoa sector appears, in general, to be much more dynamic at this point in time than the coffee sector, and there is much optimism for the cocoa 
sector. The spike in international cocoa prices may, however, be short lived and producers should be wary of over investing in a sector whose prices may decline in the future.

\section{B. Geography and Ecology of Cocoa Production}

Cocoa is grown primarily in the humid areas of the North, Northeast, East, North Central, and Central regions in flat to sloping land of up to $300 \mathrm{~m}$ elevation. The major cocoa production zone, with about $61 \%$ of land area planted to cocoa, is in the Northeast region around San Fransisco de Macoris (table IV.2). Cocoa production is considerably more geographically concentrated than coffee production, but some areas of production overlap (especially in the central mountain ranges).

Table IV.2 Spatial Distribution of Cocoa Plantings by Region, 2000/1

\begin{tabular}{|l|c|}
\hline Region & $\begin{array}{l}\text { \% of } \\
\text { Production }\end{array}$ \\
\hline Northeast & 60.8 \\
\hline East & 13.0 \\
\hline Central & 10.2 \\
\hline North & 9.4 \\
\hline Northcentral & 6.6 \\
\hline TOTAL & $100 \%$ \\
\hline
\end{tabular}

Source: "Informe Anual de las Estadísticas del Cacao 2001/2", SEA, Departamento del Cacao, Santo Domingo (2002)

Although some growing areas for cocoa and coffee overlap, coffee is grown on hillier terrains at higher elevations; cocoa is grown on more gentle slopes or flat land at lower elevations. The hilly areas where coffee is grown are subject to erosion, and coffee provides protection against erosion. Cocoa is grown on the lower slopes of mountain ranges where it offers some protection against erosion, but not to the same extent as coffee. This topography makes transport less costly in cocoa zones compared to coffee zones. Because harvested cocoa pods do not require the immediate attention needed for harvested coffee cherries, and because of the topography, it is more practical and economical to operate post-harvest facilities for groups of producers; which is important for improving quality.

\section{Overlapping Areas of Cocoa and Coffee Production}

Central Region contains about $10 \%$ of cocoa planted area and almost $25 \%$ of coffee area. The mountainous areas of Central Region are crucial for the region's and national watershed management and water quality. Interestingly, of producers in the CRMG surveys, about $12 \%$ of coffee producers inter-planted with cocoa, and about $26 \%$ of cocoa producers claimed they interplanted with coffee.

The relatively dry winter in cocoa-producing areas account for a low incidence of diseases and pests. Because of these favorable growing conditions, few agri-chemicals are typically used in cocoa production. ${ }^{54}$ Thus, the Dominican Republic has good ecological conditions for producing certified organic cocoa. In contrast to major cocoa producing countries in Africa, the Dominican Republic has not been afflicted by common diseases such as black pod disease, witches' broom,

\footnotetext{
${ }^{54}$ Secretaria de Estado de Agricultura, Departamento de Cacao, “Anuario de los Países Productores de
} Cacao" 1998 
and monilasis. Differences in disease incidence across countries mean that competitiveness depends on more than simple comparisons of yield differentials. Producers in other countries might have higher production costs related to disease prevention or treatment; costs of labor and other inputs may also vary.

\section{Quantities Produced and Exported}

Cocoa production increased from about 51,000 MT in 1991/2 to about 70,000 MT in 1997/98 with inter-year fluctuations during that period (see table IV.4). Subsequent to Hurricane Georges, the sector recovered and production in 2001/2002 was estimated to be about 46,000 MT. Export earnings from cocoa exports had grown from US\$35 million in 1991 to about US\$93 million in 1998 but then fell by $75 \%$ to only US $\$ 27$ million in 1999 . Fluctuations in production and export revenues are not new. Significant hurricane damage occurred in 1979 and 1987. In fact, the World Bank's Cocoa and Coffee Project 1982-1989 was a response to damage caused by Hurricane David in 1979. Implementation was interrupted by Hurricane Emily in 1987.

Some Dominican cocoa is processed and consumed domestically, and some is exported in a processed form. From 1990 to 2002 domestic consumption averaged about $14 \%$ of total production. A steady increase in cocoa used for internal consumption was observed from 1991 to 1998, parallel to the increases in production. Domestic consumption peaked in 1997/8 and dropped in 1998/99. Since 1999, domestic consumption has not recovered to parallel increases in production and exports. ${ }^{55}$

Table IV.4 Production and Exports of Cocoa, 1991/2-2001/2

\begin{tabular}{|l|cccc}
\hline & $\begin{array}{c}\text { Production } \\
\text { (MT) }\end{array}$ & $\begin{array}{c}\text { Internal } \\
\text { Consumption } \\
\text { (MT) }\end{array}$ & $\begin{array}{c}\text { Exports } \\
\text { (MT) }\end{array}$ & $\begin{array}{c}\text { Value of } \\
\text { Exports } \\
\text { Million USD }\end{array}$ \\
\hline $\mathbf{1 9 9 1 / 1 9 9 2}$ & 51,210 & 7,664 & 43,546 & 35.3 \\
\hline $\mathbf{1 9 9 2 / 1 9 9 3}$ & 54,552 & 8,164 & 46,388 & 34.2 \\
\hline $\mathbf{1 9 9 3 / 1 9 9 4}$ & 63,960 & 9,712 & 54,298 & 58.5 \\
\hline $\mathbf{1 9 9 4 / 1 9 9 5}$ & 60,741 & 9,091 & 51,650 & 59.3 \\
\hline $\mathbf{1 9 9 5 / 1 9 9 6}$ & 61,937 & 9,269 & 52,667 & 63.7 \\
\hline $\mathbf{1 9 9 6 / 1 9 9 7}$ & 52,442 & 7,849 & 44,594 & 59.3 \\
\hline $\mathbf{1 9 9 7 / 1 9 9 8}$ & 69,727 & 10,435 & 59,292 & 92.6 \\
\hline $\mathbf{1 9 9 8} / \mathbf{1 9 9 9}$ & 25,861 & 3,870 & 21,991 & 27.0 \\
\hline $\mathbf{1 9 9 9 / 2 0 0 0}$ & 37,107 & 4,840 & 32,367 & 26.7 \\
\hline $\mathbf{2 0 0 0 / 2 0 0 1}$ & 44,908 & 3,435 & 39,035 & 38.7 \\
\hline $\mathbf{2 0 0 1 / 2 0 0 2}$ & 45,468 & 2,150 & 44,410 & 65.7 \\
\hline Annual Average & 51,628 & 6,953 & 44,567 & 51.0 \\
\hline
\end{tabular}

Sources: various publications of the Comisión Nacional del Cacao and Secretaria de

Estado de Agricultura, Departamento de Cacao.

\section{Fermented and unfermented cocoa beans}

Cocoa beans are marketed after drying or after fermentation and drying. Fermented cocoa beans are the industry standard for export, and the Dominican Republic is the only country in the world that exports significant amounts of unfermented cocoa. International markets consider

\footnotetext{
${ }^{55}$ Actually, data on domestic consumption are estimated based on exports. And the method of estimation has changed in recent years. Therefore changes in domestic consumption are spurious.
} 
unfermented cocoa to be low quality, and it is manufactured into cocoa butter. Thus, most Dominican cocoa sells at a discount on the New York market, which quotes prices for fermented cocoa beans. The US is the primary market for unfermented cocoa, and lack of fermentation limits interests by European chocolate makers in Dominican cocoa.

The Dominican Republic's unfermented beans are known in the export market as Sanchez, and fermented beans under the name Hispaniola. Most cocoa is exported in 70kg bags as Sanchez and Hispaniola cocoa beans. Processed cocoa products accounted for about $10 \%$ the value of cocoa exports from 1998/99 to 2000/01. Processed cocoa exports include cocoa products, mainly cocoa butter (average share about 65\% from 1996/7-2001/2), but also cocoa powder, cocoa liquor and chocolate candies. ${ }^{56}$ In general, cocoa from the Dominican Republic does not have a great reputation for quality, and is not regarded as a major cocoa "origin" and does therefore not feature in many major chocolate manufacturers' product formulas. While not a good quality cocoa, Sanchez is considered a good, lower cost, cocoa for cocoa butter and powder production.

\section{A Tradition of Unfermented Cocoa Beans}

Why is the Dominican Republic the only country in the world exporting unfermented cocoa beans? U.S. importers have a preference for Dominican Sanchez cocoa for several reasons: a) it is cheaper than fermented cocoa, $b$ ) it can be used to produce cocoa butter and mixed with higher quality, more expensive cocoa beans (like mixing Robusta and Arabica coffees) to mass produce cocoa products for the U.S. market which is generally considered to dominated by chocolates of inferior quality, and c) the flavor from mixing fermented and unfermented cocoa beans is unique and desired in the U.S. market. Most U.S importers will not pay higher prices for better-quality fermented cocoa beans. But, why do Dominican cocoa producers continue to produce and market unfermented cocoa beans if they could receive higher prices for fermented cocoa beans? Dominican cocoa exports have long been concentrated in the hands of a few large commercial exporters who specifically cater to the U.S. market. These exporters have traditionally not provided price incentives for higher-quality fermented cocoa.

The Dominican industry now prefers to break with this tradition and export more fermented cocoa. Such a break will allow local producers and marketers to capture more value locally and will increase market access for Dominican cocoa. R rapid growth of exports by CONACADO, the producer cooperative that only exports Hispaniola cocoa beans, indicates that when appropriate price incentives exist, Dominican cocoa producers are willing to practice improved post-harvest techniques.

Constraints to increased Hispaniola production include the inertia of tradition, uncertainty about the profitability of fermentation, the need for better management and labor skill during harvest, the time cost of fermentation, and capital costs.

The share of fermented cocoa beans in total exports from the Dominican Republic is increasing over time; this share grew from $12 \%$ in $1998 / 99$ to about $23 \%$ in 2001/2002 (see table IV.5). This growth reflects increased investment in processing and more quality-consciousness on the part of exporters. Roughly $60 \%$ of the producers in the CRMG survey produce Sanchez cocoa; larger-scale producers are more likely to produce higher-quality Hispaniola than the smaller-scale

\footnotetext{
${ }^{56}$ The difference between cocoa beans and processed cocoa products explains some of the differences in data on cocoa exports. Some figures only report cocoa beans and consider processed cocoa as a manufacturing product.
} 
producers. $43 \%$ of farms over 10 hectares produce Hispaniola, compared to $37 \%$ of under-five hectare producers.

An econometric analysis of the determinants of Hispaniola planting using data from the CRMG survey, show that larger landholdings, controlling for all other factors, were associated with a significantly higher probability of producing Hispaniola (CRMG, 2003). Other key determinants included belonging to a sales organization and location at higher altitudes. Members of cocoa sales organizations are, holding all other factors constant, almost $40 \%$ more likely to produce Hispaniola than are producers who do not belong to such organizations. Interestingly, producers who reported suffering extreme damage from Hurricane Georges were less likely to produce Hispaniola, holding all else constant.

Table IV.5 Percentage of Volume Exported by Type of Cocoa 1998/9-2001/2

\begin{tabular}{|l|r|r|r|r|}
\hline Types of Cocoa & $\mathbf{1 9 9 8} / \mathbf{1 9 9 9}$ & $\mathbf{1 9 9 9 / 2 0 0 0}$ & $\mathbf{2 0 0 0 / 2 0 0 1}$ & \multicolumn{1}{|c|}{$\mathbf{2 0 0 1 / 2 0 0 2}$} \\
\hline Sanchez & $76.0 \%$ & $70.9 \%$ & $75.2 \%$ & $70.7 \%$ \\
\hline Hispaniola & $12.3 \%$ & $19.3 \%$ & $15.4 \%$ & $23.1 \%$ \\
\hline Processed Cocoa & $11.7 \%$ & $9.8 \%$ & $9.4 \%$ & $6.2 \%$ \\
\hline Total & $\mathbf{1 0 0 \%}$ & $\mathbf{1 0 0} \%$ & $\mathbf{1 0 0} \%$ & $\mathbf{1 0 0 \%}$ \\
\hline
\end{tabular}

Source: Secretaria de Estado de Agricultura, Departamento de Cacao "Informe Anual de las Estadísticas del Cacao 2001/2” (2002); “

Numerous attempts have been made to induce Dominican cocoa producers to practice on-farm cocoa fermentation, or to process their product through producer associations and other processors. Such attempts were a major focus of the World Bank's 1981 Cocoa and Coffee Project (World Bank, 1981), and a long-time priority of technical assistance from GTZ. Without fermentation, Dominican cocoa exports are limited to the US market. Increased fermentation will help expand markets and increase domestic value-added. Rapid growth of the producer cooperative CONACADO, which almost exclusively exports fermented cocoa, and provides price incentives that reward fermentation, indicates that a transformation toward fermented cocoa is underway in the Dominican Republic. Fermentation should lead to increased local capture by producers of value-added from the cocoa supply chain.

\section{The Cocoa Fermentation Process}

In processing Hispaniola cocoa, the beans are removed from the pod and are placed in airtight fermentation containers for a few days. During this period, sugars in the beans turn to alcohol. After a couple of days the beans are briefly exposed to air before being re-sealed. Finally they are exposed to air, but not yet put in the sun to dry, which causes the alcohols to escape from the beans. This process is not very complicated, and can be done with simple airtight containers. To produce fermentable beans, more care is needed in managing the harvest process and harvest labor must be more skilled than non-fermented harvest labor. Capital costs can also be a significant barrier to fermentation; estimates of the cost of a minimum scale fermentation and drying system are around US\$ 5,000. Donor support for fermentation projects is designed to organize growers into groups (like CONACADO) and spread these capital costs over more producers

Historically, about $90 \%$ of Dominican cocoa beans have been exported to the US (see table IV.6). In more recent years this share has been closer to $70 \%$, as the share of fermented cocoa increases and other export markets are accessed. Other important export destinations are Italy and Canada. 
Exports to Canada are on the rise, doubling from 2000/2001 to $2001 / 2002^{57}$, whereas exports to Belgium declined from about $14 \%$ in $1999 / 2000$ to about $8 \%$. In $2001 / 2$, about $50 \%$ of Dominican processed cocoa products were exported to the US, about $15 \%$ each to Puerto Rico and Holland, and about 5\% each to Columbia, Honduras, and Jamaica. All cocoa exports in 2001/02 went through the port of Haina. ${ }^{58}$

Table IV.6 Cocoa Exports by Destination Oct 2000- Sept 2001

\begin{tabular}{|l|c|c|}
\hline \multicolumn{1}{|c|}{ Country } & Quantity (bags) & Percent \\
\hline United States & 25,551 & 72.3 \\
\hline Italy & 3,185 & 9.0 \\
\hline Canada & 2,294 & 6.5 \\
\hline Holland & 1,537 & 4.3 \\
\hline Belgium & 756 & 2.1 \\
\hline Other & 2,037 & 5.8 \\
\hline Total & 35,360 & 100 \\
\hline
\end{tabular}

Source: CNC

Some Dominican cocoa is considered to be high quality and is sold in special niche markets that pay price premiums. The major specialty cocoa is organic cocoa, which is primarily exported by CONACADO. On average, CONACADO receives a premium of US $\$ 100$ per ton on Hispaniola cocoa as well as premiums for the sale of organic cocoas that can be as high as US\$250 per ton. However, despite the fact that about $90 \%$ of CONACADO's members are registered organic producers, at this point in time only $5 \%$ of its production is sold into organic markets - and CONACADO is currently the largest exporter of certified organic cocoa in the world. Organic cocoa buyers are extremely quality conscious and efforts to increase market shares of organic cocoas must include quality control through the production and marketing chains. Achieving organic production together with high quality cocoa beans has been a constraint for CONOCADO expanding its sales of organic cocoa.

The CRMG survey of cocoa producers indicated that about $22 \%$ are selling at least part of their production through specialty markets. Organic cocoa was the most dominant type of specialty market for Dominican producers (19\% of producers), followed by Fair Trade cocoa (2\% of producers).

\section{Structure of Production}

Smallholder producers dominate the cocoa sector in the Dominican Republic. A survey by SEA in 1980 indicated that cocoa was grown on about 115,000 hectares by about 35,000 farmers, and that $84 \%$ of the cocoa farms had fewer than 5 hectares in cocoa (World Bank, 1981, p.9). In 1998 , cocoa was grown on about 153,000 hectares by about 40,590 producers (SEA, 1998). Over the period, land planted to cocoa increased by about $33 \%$ and the number of producers grew by about $17 \%$. By 1998 , about $68 \%$ of producers had less than 5 hectares. Despite this trend towards larger cocoa landholdings, in 1998 almost one-half of all cocoa producers had less than 3 hectares of land planted to cocoa (see table IV.7). The $4 \%$ of cocoa producers with planted areas greater then 20 hectares account for about $20 \%$ of cocoa land area. In comparison to coffee,

\footnotetext{
${ }^{57}$ Secretaria de Estado de Agricultura, Departamento de Cacao “Informe Anual de las Estadísticas del Cacao 2001/2" 2002.

${ }^{58}$ Secretaria de Estado de Agricultura, Departamento de Cacao "Informe Anual de las Estadísticas del Cacao 2001/2" 2002.
} 
cocoa has relatively fewer very small scale producers and is characterized by less-pronounced dualism.

Table IV.7 Cocoa Land Area Distributed by Size of Producers, 1998

\begin{tabular}{|r|r|r|r|r|}
\hline In Hectares & \multicolumn{1}{|l}{$\begin{array}{l}\text { \# of } \\
\text { Producers }\end{array}$} & $\begin{array}{l}\text { \% } \\
\text { Producers }\end{array}$ & $\begin{array}{l}\text { Area in } \\
\text { Hectares }\end{array}$ & \multicolumn{1}{l|}{$\begin{array}{l}\text { \% } \\
\text { Land }\end{array}$} \\
\hline$<1.6$ & 1227 & 3.2 & 904 & 0.6 \\
\hline $1.6-3.1$ & 16255 & 40.1 & 22382 & 14.6 \\
\hline $3.2-5.0$ & 9957 & 24.5 & 31029 & 20.3 \\
\hline $5.1-10$ & 7555 & 18.6 & 36988 & 24.2 \\
\hline $10.1-20$ & 3785 & 9.3 & 30853 & 20.2 \\
\hline$>20$ & 1761 & 4.3 & 30836 & 20.2 \\
\hline TOTAL & 40,590 & $100 \%$ & 152,992 & $100 \%$ \\
\hline
\end{tabular}

Source: Secretaria de Estado de Agricultura, Departamento de Cacao, "Anuario de los Países Productores de Cacao" 1998.

\section{Cultivation Practices and Technology}

Traditional cocoa plantings consist of mixes of traditional Amelonado and Trinitarito varieties. Many plantations have a high proportion of trees more than 35 years year old, the age at which production begins to decline. Fewer than $40 \%$ of cocoa trees in Dominican farms are estimated to be of a prime growing age. ${ }^{59}$ Traditional plantations are characterized by a low tree populations and excessive shade trees (usually Erythrina). In some cases there are voids in the cocoa plantations, and the lack of appropriate shading can cause unbalanced plant nutrition and weed proliferation. Many traditional producers do not practice appropriate pruning or fertilization, and experience lower yields as a result.

More progressive cocoa producers have adopted improved cultivation techniques using hybrid varieties and higher density plantings of cocoa trees, improved shade tree management, improved plant nutrition using organic or chemical fertilizers, preventative disease and pest management, and appropriate pruning. Adoption of these improved technologies requires additional labor inputs, finance and higher intensity of management. To achieve sustainable increases in productivity, the Cocoa Department acknowledges the need to introduce better varieties of cacao and improve production techniques. The destruction caused by Hurricane Georges has helped transform the cocoa industry; post-Georges rehabilitation focused on replanting and rehabilitation with an improved hybrid variety. Current estimates are that $60 \%$ of existing plantations are in traditional varieties, while $40 \%$ are newer hybrids. In comparison, in Cote d'Ivoire and Ghana about $70 \%$ of cocoa area is planted to hybrids, and in Ecuador about $35 \%{ }^{60}$

The Cocoa Department in SEA classifies cocoa producers into three rough typologies. The first type uses no purchased inputs, minimum maintenance, and produces for own-consumption with surplus going to the market. Yields among such producers are about $250-300 \mathrm{~kg} / \mathrm{ha}$. The second type of producer has conducted renovation with improved varieties, uses good management and

\footnotetext{
${ }^{59}$ Secretaria de Estado de Agricultura, Departamento de Cacao, “Anuario de los Países Productores de cacao" 1998.

${ }^{60}$ Secretaria de Estado de Agricultura, Departamento de Cacao "Informe Anual de las Estadísticas del Cacao 2001/2” 2002.
} 
has yields of between $700-1100 \mathrm{~kg} / \mathrm{ha}$. These tend to be larger-scale farmers with average plantings of 100-200 tareas. The third type is a CONOCADO producer who produces organic cocoa with good techniques where yields vary between $700-1300 \mathrm{~kg} / \mathrm{ha}$. The wide range in estimates reflects different levels of management.

\section{Cocoa Production and Household Income}

Because of its pronounced seasonal labor and cash flows and the common practice of interplanting cocoa plantings with other trees and crops, cocoa production is often a part of a producer household's diversified income generating activities. The degree of diversification is important for household decisions on labor and capital allocation to different enterprises and also affects self-financing and management of price and yield risks. Following the cocoa price declines of the 1990s and Hurricane Georges, many small-scale producers moved their families near urban centers in search of more remunerative economic prospects. Some returned to their farms following rehabilitation efforts and the subsequent spike in world prices, but many still live outside the areas of production and manage their farms on an irregular basis. It will be interesting to observe how these "part-time" producers manage their farms.

In the CRMG survey, over $50 \%$ of cocoa producers indicated they received $50 \%$ or more of their on-farm income from cocoa sales, while $44 \%$ of the producers received $50 \%$ or more of total household income from on-farm activities. This indicates a fairly high degree of income diversification. The survey indicates that smaller cocoa producers are likely to receive about $50 \%$ of their income from the farm, with the larger and the very smallest producers being less diversified and receiving higher shares of income from cocoa.

The CRMG survey results are comparable with the results of a survey of cocoa producers conducted by a leading cocoa export firm Nazario Rizek that indicate cocoa producing households who market with Rizek have diversified sources of income. At almost 39\% average share of household gross income, cocoa represents the single most important source of income for cocoa producing households, but clearly other sources of income are important (see table IV.9).

Table IV.9 Cocoa as Share of Producer's Income

\begin{tabular}{|l|l|l|}
\hline & Revenues RD\$ & Percent \\
\hline Cocoa Sales & 25,629 & 38.6 \\
\hline Other Crops & 12,959 & 19.5 \\
\hline Livestock & 3,471 & 5.2 \\
\hline Remittances & 6,035 & 9.1 \\
\hline Colmado (Petty Trading) & 2,647 & 4.0 \\
\hline Moto-Taxi & 1,059 & 1.6 \\
\hline Salaries/Labor Income & 3,706 & 5.6 \\
\hline Cash in Bank or Coop & 2,029 & 3.1 \\
\hline Money Owed & 6,529 & 9.8 \\
\hline Other & 2,412 & 3.6 \\
\hline Total & 66,476 & $100 \%$ \\
\hline
\end{tabular}

Source: Nazario Rizek; 107 Producers Surveyed in 2002, Average Farm Size 5.7 Ha.

Note: Estimated value in US\$ based on mid-July 2002 exchange rate of 1 US\$/17\$RD\$. 
Labor is the major input for cocoa production. The peak labor demand is felt during the two harvest periods. The main cocoa harvest is from April to June, and the "fly," or smaller crop, is harvested in October to December. Other major labor demands are for weeding and pruning (March, August) and activities related to fertilization and control of diseases and pests. Labor demand depends on yields and the extent to which "best practices" are used.

As is the case with coffee, no reliable data exist on total employment in cocoa production and marketing. The available labor pool for production has been influenced by out-migration to urban centers, especially by younger male adults, but experts in cocoa indicated that labor shortages in cocoa are not a serious problem. Most cocoa labor is Dominican, so, unlike coffee, problems associated with Haitian migrants do not have a major direct affect on the cocoa industry. Small-scale farmers rely on family labor to work the farm during the year with the exception of the harvest period. During harvest only about $50 \%$ of labor on medium-sized and semi-technified farms is family labor. Some small-scale farmers also tend to work on larger farms as wage laborers, and many seek work outside of agriculture.

\section{Cocoa Producer Perceptions of Risks}

The CRMG survey asked producers to rate several risks in terms of their importance. Risks associated with cocoa prices, weather, diseases and pests, and access to credit all received similar scores (all were scored 2.6 and above on a 1 to 3 scale where 1 was not important, 2 important, and 3 very important). No significant variation in results was found by landholding size. Cocoa producers, like coffee producers, perceive that they are operating in a risky environment - despite the current upswing in international cocoa prices.

\section{Weather Risks}

Hurricane Georges caused significant damage to the cocoa sector. Hurricanes in 1987 and 1979 were also damaging. Post-Georges rehabilitation provided an opportunity to upgrade the productive stock and massive replanting efforts followed.

About $95 \%$ of producers surveyed in the CRMG survey indicated their production suffered as a result of Hurricane Georges, and $20 \%$ of producers indicated that $81-100 \%$ of their production was affected (see tables IV.10a\&b ). About $80 \%$ of all producers in the CRMG survey said that weather risk was "very important." Producers who suffered severe damage from Georges were less likely to engage in Hispaniola production and, while the results are not definitive, they suggest that hurricane risk is a constraint to improved quality.

Table IV.10a Cocoa Producers Affected by Hurricane Georges

\begin{tabular}{|l|l|}
\hline Did your farm production suffer from Hurricane George? & $96 \%$ YES \\
\hline Did you replant cocoa since that time? & $59 \%$ YES \\
\hline
\end{tabular}

Table IV.10b Production Losses for Cocoa Producers Affected by Hurricane Georges

\begin{tabular}{|l|l|l|l|l|l|l|}
\hline Percent production loss & None & $1-20 \%$ & $21-40 \%$ & $41-60 \%$ & $61-80 \%$ & $81-100 \%$ \\
\hline Percent producers in category & $6 \%$ & 13 & $20 \%$ & 19 & $22 \%$ & $20 \%$ \\
\hline
\end{tabular}




\section{Diseases and Pests}

As mentioned previously, diseases and pests not a major problem for cocoa production, because of agro-ecological conditions, especially the relatively dry winter months. This allows Dominican cocoa producers to use little or no agri-chemicals, and produce certified organic cocoa. In fact, a growing share of cocoa producers are tapping into the certified organic cocoa market, and the number of producers seeking such certification is growing. The primary pest problem is rats and rat control is a high priority of the Cocoa Department. Organic producers use snakes as a means of biological control, and others use chemical raticides.

Despite evidence that diseases are not overly important for Dominican cocoa producers, more than $65 \%$ of respondents to the CRMG survey cited diseases as a very important form of yield risk. Disease risk was judged to be more important for smaller-scale producers, but over $60 \%$ of the largest-scale producers stated it was very important.

\section{Credit}

Little institutional credit goes to cocoa producers. Some cocoa producers have access to credit through Banco Agricola which used to lend more to cocoa producers, but in recent years this funding has dried up. Exporters are the principal source of financing for cocoa producers. Shortterm financing by exporters-- "harvest loans" -- has a long tradition in the cocoa sector. Due to competition in the sector among exporters for purchase of cocoa beans, larger exporters have began to dominate the market and provide producers with pre-harvest credit to serve as guarantee of a forward selling contract. Intermediaries also provide some financing.

Producers typically have a long-standing relationship with a single exporter or exporter agent. Repayment of a loan is deducted from the final sale of the cocoa. In the case of longer-term loans the exporter requires a tangible guarantee, or collateral such as a land title. In both cases, interest rates are roughly equivalent to those charged by commercial banks.

About $40 \%$ of producers surveyed by CRMG reported that they had access to production credit. Most credit is from exporters (14\%) and intermediaries (7\%) (see table IV.11). Credit provided by exporters and intermediaries appears to be targeted toward larger-scale producers. By contrast, credit coming from either Banco Agricola or commercial banks, is not related to farm size. The category 'other' for sources of credit likely refers to remittances and or informal borrowing between other family members or neighbors. About $80 \%$ of small and medium-scale producers indicate that lack of credit is a "very important" form of risk.

A probit analysis of the determinants of credit uptake using the CRMG data shows that although larger farms were more likely to access production credit, landholding size is not a statistically significant determinant of credit use (CRMG, 2003). Better-educated farmers are marginally more likely to access production credit. Farmers with higher proportions of farm income coming from cocoa and those who specialized in farming (had larger income shares from on-farm sources) were more likely to access credit. These results suggest that cocoa credit markets serve growers who specialize in cocoa, but few other producers find regular access to credit. 
Table IV.11 Sources of Credit for Cocoa Producers: CRMG Survey Results

\begin{tabular}{|l|l|}
\hline & Total Avg. \\
\hline $\begin{array}{l}\text { Cocoa Producers } \\
\text { Receiving credit (Total) }\end{array}$ & $41 \%$ \\
\hline Source of credit: & \\
\hline Exporter & $14 \%$ \\
\hline Intermediary & $7 \%$ \\
\hline Cooperative & $1 \%$ \\
\hline Agricultural Bank & $3 \%$ \\
\hline Money lender & $1 \%$ \\
\hline Commercial Bank & $9 \%$ \\
\hline Other & $14 \%$ \\
\hline CRMG Survy (Word
\end{tabular}

CRMG Survey (World Bank, 2002a)

\section{Environmental externalities}

Cocoa production can have positive environmental impacts, but the industry's environmental impacts are not viewed as being as important as are those of coffee. Major producing areas are located outside important watersheds. Since cocoa is a perennial tree crop, often grown under shaded conditions, it reduces soil erosion and helps maintain forested areas. Since cocoa is located on gentler slopes on level land, it does not have an equivalent impact on preventing erosion as does coffee. Outside of erosion control, organic cocoa production tends to be more environmentally benign than coffee production. Post-harvest processing of coffee uses considerable quantities of water, compared to cocoa post-harvest processes - either fermented or unfermented.

There is some overlap of cocoa and coffee production in the mountainous areas of Central Region. In these areas, coffee is grown on hillsides at higher elevations and cocoa at lower elevations. Environmental impacts of coffee and cocoa production on soil erosion, leaching of agri-chemicals and water borne wastes, are all linked to watershed quality. Production and postharvest activities in the two industries should be managed in a way that considers the impacts of these activities on watershed quality.

\section{E. Structure of Marketing and Exports}

The chain of post-harvest activities begins on the cocoa farms, moving on to actors such as intermediaries, exporters, and domestic processors. Since we have already devoted considerable attention to producers and post-harvest practices, we begin this section with intermediaries.

\section{E.1 Cocoa Intermediaries}

Intermediaries purchase cocoa beans from producers at the farmgate or nearby villages. Some buy cocoa beans and sell them to exporters, while a larger share of intermediaries act as purchasing agents for exporters. Large commercial exporters use intermediaries as local purchase agents. Approximately 1000 agents currently work as intermediaries in the Dominican Republic. Exporters also buy directly from the larger producers and from associations of producers, and some producers deliver their cocoa beans directly to the exporters

Intermediaries can be categorized into four general groupings: 
1. Traders: exchange rice or other goods for cocoa to very small-scale producers who typically dry their cocoa on the side of the road.

2. Mobile intermediaries: drive to farmers and buy on the farm; many times they are representatives of exporters or other intermediaries

3. Stationary intermediaries: set up purchasing centers in larger villages and towns

4. Export buyers: large exporters who buy directly from producers

Most exporters have a pre-determined marketing margin and set buying prices by subtracting this margin from the international price. While the small number of large exporters makes for an oligopoly structure between which prices vary little, local intermediaries compete for market share and it is common that prices offered by intermediaries vary. Producers tend to get information on cocoa prices via radio; prices are broadcast several times a day during harvest season. The internal cocoa marketing system seems fairly transparent and competitive.

Historically intermediaries have not paid differential prices for better quality beans, even if they are fermented, because exporters were mainly targeting export markets in the US, where unfermented cocoa is in demand. The long time one-price policy of intermediaries, although fair for producers of low-quality cocoa, has provided a disincentive for other producers to improve cocoa quality. A change in pricing practices would require a change in signals from the exporters. A clear and transparent system of quality standards is needed before the market can transmit quality signals more effectively. Representatives of the industry noted that such standards will be provided by the Cocoa Council (more below) once it is created.

Table IV.12 Marketing Channels Used by Producers

\begin{tabular}{|l|c|}
\hline Exporter & $34.3 \%$ \\
\hline Intermediary & $38.9 \%$ \\
\hline Cooperative & $6.3 \%$ \\
\hline Producer Association & $16.6 \%$ \\
\hline Other & $9.6 \%$ \\
\hline
\end{tabular}

Source: CRMG Survey

The CRMG survey indicates the importance of commercial exporters in the direct purchasing of cocoa, with about $34 \%$ of respondents reported marketing their cocoa through a commercial exporter (see table IV.12) ${ }^{61}$. Intermediaries accounted for about $39 \%$ of the purchases. About $17 \%$ of respondents marketed though producer associations and $7 \%$ through cooperatives, but producer associations act as aggregators and export via cooperatives.

\section{E.2 Cocoa Exporters}

Cocoa exports are concentrated among five exporters, four of which are commercial firms and one is a large producer cooperative. Historically in the Dominican Republic there have been four dominant exporting firms (some of whom also export coffee) and they collectively exported about 90 to $95 \%$ of Dominican cocoa. Two firms - Nazario Rizek and Commercial Roig accounted for about $70-75 \%$ of all cocoa exports. In the past five years, this domination of cocoa exports has been challenged by the CONOCADO producers cooperative (see table IV.13). As of 2002 , CONOCADO had some 11,000 members, about $25 \%$ of all cocoa producers, and the highest market share of all exporters.

\footnotetext{
${ }^{61}$ A clear bias of the survey is obvious from table IV.12: the sample did not represent the large number of small-scale producers who joined CONACADO, a cooperative, in recent years.
} 
Table IV.13 Share of Cocoa Exports (Average 1996/7-2001/2) by Major Exporters

\begin{tabular}{|c|c|c|c|c|c|c|}
\hline & \multirow[t]{2}{*}{$1996 / 97$} & \multirow[t]{2}{*}{$1997 / 98$} & \multirow[t]{2}{*}{ 1998/99 } & \multirow[t]{2}{*}{$1999 / 2000$} & \multirow[t]{2}{*}{$2000 / 01$} & \multirow[t]{2}{*}{ 2001/02 } \\
\hline Commercial Firms & & & & & & \\
\hline Nazario Rizek & $34 \%$ & $37 \%$ & $36 \%$ & $27 \%$ & $37 \%$ & $27 \%$ \\
\hline Comercial Roig & $29 \%$ & $27 \%$ & $28 \%$ & $26 \%$ & $29 \%$ & $21 \%$ \\
\hline Munne \& Co. & $13 \%$ & $11 \%$ & $13 \%$ & $15 \%$ & $9 \%$ & $9 \%$ \\
\hline Paiwonsky & $8 \%$ & $7 \%$ & $6 \%$ & $5 \%$ & $6 \%$ & $4 \%$ \\
\hline Garcia \& Mejia & $3 \%$ & $4 \%$ & $5 \%$ & $3 \%$ & $2 \%$ & $3 \%$ \\
\hline Cacaoinsa & $7 \%$ & $7 \%$ & $2 \%$ & $7 \%$ & $1 \%$ & $0 \%$ \\
\hline Others & $1 \%$ & $>1 \%$ & $>1 \%$ & $1 \%$ & $2 \%$ & $1 \%$ \\
\hline Sub-Total & $95 \%$ & $93 \%$ & $90 \%$ & $84 \%$ & $86 \%$ & $66 \%$ \\
\hline \multicolumn{7}{|l|}{ Cooperatives } \\
\hline Conacado & $5 \%$ & $6 \%$ & $10 \%$ & $16 \%$ & $11 \%$ & $30 \%$ \\
\hline Aprocaci & $>1 \%$ & $1 \%$ & $>1 \%$ & $>1 \%$ & $2 \%$ & $2 \%$ \\
\hline Yacao & $>1 \%$ & $>1 \%$ & $>1 \%$ & $>1 \%$ & $1 \%$ & $2 \%$ \\
\hline Sub-Total & $5 \%$ & $7 \%$ & $10 \%$ & $16 \%$ & $14 \%$ & $34 \%$ \\
\hline
\end{tabular}

Source: Secretaria de Estado de Agricultura, Departamento de Cacao "Informe Annual de las Estadsticas del Cacao 2001/2" 2002.

CONOCADO dominates the market for Hispaniola and certified organic Hispaniola, but Nazario Rizek has also entered into this export market (see table IV.14). Other producer associations established in the 1990s (e.g., Aprocaci and Yacao) are experiencing growth in exports and market share and are trying to produce and export Hispaniola and organic cocoa.

Table IV.14 Share of Hispaniola Cocoa Exports (Average 1997/8-2001/2) by Major Exporters

\begin{tabular}{|l|r|r|r|r|r|} 
& \multicolumn{1}{|c|}{$\mathbf{1 9 9 7 / 9 8}$} & $\mathbf{1 9 9 8 / 9 9}$ & $\mathbf{1 9 9 9 / 2 0 0 0}$ & $\mathbf{2 0 0 0 / 0 1}$ & $\mathbf{2 0 0 1 / 0 2}$ \\
\cline { 1 - 1 } Nazario Rizek & $5 \%$ & $41 \%$ & $19 \%$ & $16 \%$ & $27 \%$ \\
\hline Comercial Roig & $1 \%$ & $0 \%$ & $0 \%$ & $0 \%$ & $0 \%$ \\
\hline Conacado & $92 \%$ & $59 \%$ & $73 \%$ & $64 \%$ & $63 \%$ \\
\hline Aprocaci & $1 \%$ & $0 \%$ & $0 \%$ & $5 \%$ & $0 \%$ \\
\hline Yacao & $0 \%$ & $0 \%$ & $0 \%$ & $9 \%$ & $7 \%$ \\
\hline Total & $99 \%$ & $100 \%$ & $92 \%$ & $94 \%$ & $97 \%$ \\
\hline
\end{tabular}

Source: Secretaria de Estado de Agricultura, Departamento de Cacao "Informe Annual de las Estadsticas del Cacao 2001/2" 2002.

\section{Nazario Rizek C. Por A.}

The Nazario Rizek company has long dominated the cocoa market in the Dominican Republic, and is also an exporter of coffee. Rizek has mobile purchasing agents who go to farms and villages to purchase cocoa beans. Rizek also provides substantial amounts of short-term credit for working capital. Loans are typically $40-50 \%$ of the expected FOB value for pre-harvest finance. Rizek also allows farmers to fix a price up to 10 months in advance on $10 \%$ of total expected production. During harvest Rizek sets the prices twice daily, by subtracting a standard marketing margin from the international price, and communicates that price to his purchasing agents. Producers who sell their cocoa to Rizek may take the spot price but also can deliver their 
cocoa to the warehouse and wait until the end of the season to set the price. This is a simple informal form of "price risk management" for producers.

Rizek has demonstrated an interest in increasing exports of Hispaniola cocoa which its view as a means of increasing prices and increasing the market for Dominican cocoa. It was actively involved in USAID-financed post-Georges rehabilitation programs and have since widely promoted, through subsidized seedling prices, the upgrading of cocoa plantations to hybrid varieties.

\section{CONACADO (National Confederation of Dominican Cocoa Cultivators)}

CONACADO, formed in 1988, is a non-profit cooperative with a membership of about 11,000 small- and medium sized cocoa producers. The majority of CONACADO members have three or fewer hectares of cocoa. CONOCADO provides marketing, extension, and financial services (mostly pre-harvest credit). CONACADO also provides internal quality certification and internal organic certification. Over $90 \%$ of CONACADO's producers are certified organic. At present, CONACADO is the largest producer and exporter of organic cocoa in the world.

CONACADO purchases through their nine member blocks. Farmers receive the international price less a marketing margin. Benefits that CONACADO receives because of fair trade or organic contracts are passed back to farmers in the form of a second payment. CONACADO charges US $\$ 1.29$ commission on every sack of cocoa exported (approx. 1.5- 2.0\% of exported value). This money is paid into a Treasury Fund used to sponsor administration, training, transportation and marketing activities. CONACADO receives technical assistance from GTZ and USAID to help improve marketing and extension services for its members.

CONCADO receives loans from commercial (local and international) banks and offers credit services to its producers through their blocks. CONACADO has a standing relationship with Banco International (Baninter), a local commercial bank, and receives over $90 \%$ of its credit from this institution. In order to receive this credit CONACADO has placed over US\$2 million as collateral with BanInter. Producers receive two types of credit from CONOCADO: a) credit for production and household consumption, and b) credit for harvest. Production and consumption credit is typically 9 months in duration and cannot exceed $30 \%$ of expected production. Harvest credit is awarded for periods of 21-30 days from April to July based on harvest estimates. About $70 \%$ of CONACADO's members receive credit from the cooperative. CONOCADO management believes that more members are interested in obtaining credit and those already receiving credit would be interested in accessing larger loans than currently available.

CONOCADO recognizes that production of organic cocoa alone is not enough to secure market share in the increasingly competitive international organic market. They are continually emphasizing quality improvement and devote a significant amount of technical assistance to quality improvement among members.

\section{E.3 Domestic Cocoa Market}

Some Dominican cocoa remains in the domestic market. Local processors include Munne \& Co., Cortes Hermanos \& Co., and others. Informal processing exists in rural areas, but quantities are relatively insignificant. Estimates of quantities of local marketed cocoa are unreliable since they come from the difference between uncertain production figures and export. Information on stocks is not well-documented. The Cocoa Commission has plans to support and expand local processing. 


\section{E.4 Estimates of Marketing Margins}

Attempts to try and generalize marketing margins are difficult because of the difficulty to obtain accurate and consistent data from all those involved in the marketing chain. Thus, we will present some indicative estimates of marketing margins that are based on several sources.

Cocoa exporters and intermediaries set prices paid to producers based on international commodity market prices, from which they deduct a fixed margin. This margin has two components: a) the marketing margin from the exporter's warehouse in the Dominican Republic to the export destination, and $b$ ) the marketing margin from the farmgate to the exporter's warehouse. Clearly there will be differences in component depending on whether the cocoa is exported to the US or Europe (or other destinations).

On May 30, 2003 the NYBOT price for fermented cocoa about US\$1400/MT, and the price differential for unfermented cocoa was minus US\$100/MT. The FOB price for Dominican cocoa is about $\$ 120-130 /$ MT less (for broker and freight charges). Cocoa Commission levies and repayment of the emergency credit accounts for another US\$120/MT. Costs from farmgate to exporter (including processing, transport, profit margins for processors, etc.) accounted for another $\$ 200 /$ MT. The farmgate price was estimated to be about US\$800-850/MT for Sanchez cocoa. Thus, farmgate prices for Sanchez were about $80 \%$ of FOB prices. A marketing margin of $20-25 \%$ from FOB to farmgate seems to be the accepted reference margin for cocoa.

\section{F. Other Cocoa-related Institutions}

Cocoa institutions include actors from the public and private sectors, public-private sector hybrids, international development agencies and NGOs. These institutions have different functions and their roles have been changing over time. Unlike the coffee sector, cooperatives (especially CONOCADO) have become major players in the cocoa sector. International development agencies and NGOs have not been involved to the extent that they are in coffee, but CONOCADO has received considerable assistance.

The major functions and services provided by public institutions and development agencies include: collection and dissemination of data and information, provision of research and technical assistance, regulation of input and output markets, provision of marketing and export services, and financial services, and formulation of overall cocoa sector strategies and influencing the overall policy environment.

\section{F.1 Government}

The government's primary direct roles in the cocoa sector, carried out by the Department of Cocoa in the Ministry of Agriculture, include data collection and dissemination, research and extension, and some Government funded programs targeted to cocoa producers. The Comisión Nacional de Cacao (CNC) is a semipublic organization that was spun off from the Ministry of Agriculture as a part of decentralization. The focus of the CNC is primarily on policy. It is presided over by the Ministry of Agriculture, and its Board of Directors has representatives from the private sector including exporters, producers and representatives of the cocoa processing industry. The $\mathrm{CNC}$ is also the Dominican representative to the International Cocoa Organization (ICCO). Its operating budget is based on a 0.75 US\$ (12 RD\$) "voluntary" contribution on every kilo exported. Because it receives financial support from the state it is not formally an 
industry organization. Currently, the annual budget of the Department of Cocoa is about RD $\$ 100$ million and the Cocoa Commission about RD $\$ 10$ million.

The CNC is tasked with maintaining the quality of exported cocoa and runs a free quality control lab for this process. It certifies Dominican cocoa and grants export licenses. The CNC currently retains a portion of export proceeds to repay the loan granted to the cocoa sector for recovery efforts from Hurricane Georges (as detailed in section D.2).

The Department of Cocoa in the Ministry of Agriculture and the CNC collaborate on projects but are not formally linked. A bill currently before the Senate and being reviewed by the Agropecuario Subcommittee would put all cocoa activities outside the Ministry of Agriculture into parastatal body. This new organization, Consejo Dominicana de Cacao (CODOCACAO), would run much like CODOCAFE. CODOCACAO would be a permanent, autonomous organization whose decision making power would lie with a mix of public and private sector institutions. CODOCACAO would undertake the same variety of activities currently done by the Cocoa Department. It would be responsible for research and cocoa extension, and will be tasked with advocating construction of infrastructure necessary to improve quality through post harvest fermentation.

The Matalarga Agricultural Experiment Station near San Francisco de Macoris conducts research on cocoa in the Dominican Republic. Its major research priorities are investigations into the productivity of soils, control of pests and diseases, and the economic effects of increased diversification. The Cocoa Department has some 102 area extension agents who are promoting improved harvest and post-harvest management of the crop. In addition, these agents promote increased diversification through use of fruit trees as shade. Field days and short-term training in cocoa focus on quality improvement, pruning, rat control and production and care of grafted stock. Technical assistance for coffee and cocoa growers comes from public and private sources. Some technical assistance also comes from SEA extension workers who are not specialized in cocoa, but work in cocoa areas. These agents sometimes provide technical assistance to cocoa producers and producer associations. Larger producer associations and cooperatives also have their own employees who provide technical assistance.

A major program of the Cocoa Department at the present is renovation and rehabilitation of some 13,000 hectares of cocoa area to increase productivity and quality of cocoa. This program follows and builds upon the lessons learned by the post-Georges rehabilitation efforts. During that effort, the Cocoa Department provided seedlings and technical assistance and producers were lent RD \$ 300 per hundredweight of base production to support rehabilitation. The American Cocoa Research Institute also provided a US\$ 1 million grant. Recently, the main focus of extension efforts have been to improve management during harvest and post-harvest with the objective of increasing output of Hispaniola.

\section{F.2 International Development Agencies and NGOs}

Several international development agencies and NGOs are involved in the cocoa sector. The focus of their programs has been on providing technical assistance and capacity building needed to improve cocoa quality - notably fermentation of cocoa beans to produce Hispaniola cocoa-, production of organic cocoa, and facilitation of exports to markets where Dominican cocoa can be sold at a premium. Direct assistance from international development agencies and NGOS for the cocoa sector has tended to be considerably less than for the coffee sector. 
In the past 10 years, a major beneficiary of international development agencies and NGOs has been CONOCADO, and this has helped CONOCADO successfully expand its membership and exports, to adopt improved production technologies (e.g., organic certification), post-harvest (e.g., fermentation) practices, and access new markets in Europe. CONOCADO has also been helped by having access to credit at preferential interest rates and terms, which it could on-lend to members and use to purchase fermentation equipment. The "success" of CONOCADO will have to be judged in upcoming years, to see whether this rapid expansion of membership and activities is sustainable.

Table IV.16 Donor Funds in Support of CONACADO

\begin{tabular}{|l|l|}
\hline Donor & Purpose \\
\hline Helen Bader Fund & Improve the quality of cocoa throughout the Northeast region. \\
\hline USAID & Support women's micro-agro industries in cacao growing areas (East, Central \& N. East) \\
\hline $\begin{array}{l}\text { Counter party } \\
\text { funds }\end{array}$ & $\begin{array}{l}\text { Sponsor the purchase and sale of cacao from groups who do not have a relationship with } \\
\text { a specific block. }\end{array}$ \\
\hline GTZ Fund & $\begin{array}{l}\text { Generates } 24 \% \text { interest, 14\% is re-capitalized in the fund \& the rest is utilized for } \\
\text { operational costs. }\end{array}$ \\
\hline
\end{tabular}

\section{USAID}

USDA spent more than US\$4 million on cocoa rehabilitation from 1999-2001, with the funds coming from monetized wheat donations. The projects involved replanting, infrastructure development (drying and fermentation), nurseries and technical assistance. Part of USAID's US\$16 million recovery program after Hurricane Georges was to help Dominican farmers restore their agricultural production. Some cocoa producers have benefited from this program. USAID initiated partnerships with the American Cocoa Research Institute, the government, universities and NGOs to promote quality cocoa. During this recovery project more than 10,500 farms received assistance to improve livestock quality and agricultural productivity of key cash crops.

\section{G. Competitiveness of the Cocoa Sector}

Currently in the cocoa sector there is optimism for increased future production as well as increased prices for Dominican cocoa. This optimism is due in part to high international prices, and increased capacity in the sector to promote quality control issues, fermentation, and organic prodution.

The Dominican cocoa sector is working to take advantage of niche markets for its cocoa. Along with exports of organic and fair trade cocoa, many producers have introduced a fermentation process in order to differentiate Dominican cocoa. Hispaniola cocoa sells at a premium to specialty chocolate makers in Europe, and exporters are paying a premium for good-quality Hispaniola cocoa. As mentioned before 90\% of CONACADO's producers are already organically certified and at this point their supply of organic cocoa outstrips the demand (although part of the constraint is the poor quality of some of the organic cocoa).

The cocoa sector faces two major challenges for future competitiveness:

1) Of cocoa trees on Dominican farms only an estimated $30-40 \%$ of the trees are of a prime growing age and improved varieties. Some of the other cacao trees are in deterioration and 
advanced in age, between 45-60 years old. In order to see marked improvements in the cocoa sector there is a need to continue introducing better varieties of cacao and improving the techniques of producing cocoa (e.g., planting densities). There have been major renovation and rehabilitation efforts after Hurricane George, and this has led to changes in the cocoa sector to achieve these aims.

2) Recent activities by the government and by the donor community have been focused on the adoption of improved varieties to increase productivity, on cocoa fermentation practices to increase farmgate prices, and to improve access to markets that pay a premium for quality and specialty cocoa. As national cocoa production increases, it is important to continue these efforts to guarantee access to a larger market.

The major advantage for future competitiveness is agro-ecological conditions that allow for production of organic cocoa. Competing countries are less able to produce organically because of pests and diseases that are absent in the Dominican Republic.

As emphasized in the section on competitiveness of the coffee sector, comparisons based on average yields and costs of production are not particularly helpful, considering the available data. Nevertheless, comparing yields among several countries, the Dominican Republic seems fairly competitive in terms of average yields in the mid-1990s. As can been seen in table IV.17, average national yields fell dramatically over the past few years which is almost entirely due to the effects of Hurricane George. Dominican yields are relatively high because of the lack of diseases other nations contend with.

IV. 17 International Comparison of CocoaYields (kg/ha)

\begin{tabular}{|c|c|c|c|c|c|}
\hline $\begin{array}{c}\text { 3 year } \\
\text { Avg. }\end{array}$ & $\begin{array}{c}\text { Dominican } \\
\text { Republic }\end{array}$ & Brazil & Ecuador & $\begin{array}{c}\text { Cote } \\
\text { d'Ivoire }\end{array}$ & Ghana \\
\hline $\mathbf{1 9 9 9 - 0 1}$ & 290 & 290 & 340 & 570 & 300 \\
\hline $\mathbf{1 9 9 6 - 9 8}$ & 450 & 390 & 210 & 570 & 330 \\
\hline $\mathbf{1 9 9 3 - 9 5}$ & 460 & 450 & 250 & 560 & 400 \\
\hline
\end{tabular}

Source: FAO website. 


\section{CHALLENGES and STRATEGIES for the COFFEE and COCOA SECTORS}

The coffee and cocoa sectors in the Dominican Republic face major challenges, some from external sources and others internal. External challenges include fluctuations in global markets and hurricane hazards. Internal challenges include problems in the marketing systems and imperfections in input markets. Both types of challenges require proactive strategies; neither is insurmountable. We examine both commodities together because of the similarities in challenges and strategies; while in certain cases, the differences are illuminating. Several countries in Central America and the Caribbean have found themselves in similar situations with respect to the export of primary commodities such as coffee and cocoa. Many are following similar recommendations and pursuing similar strategies. This overlapping of interests justifies greater regional coordination of efforts (e.g. the regional USAID specialty coffee initiative that includes five Central American countries and Dominican Republic). Alternatively, if all countries in the region adopt similar strategies they will be competing for the same market niches, and this competition might create a new cycle of problems.

\section{A. Overview of Strategies for the Coffee Sectors of Central America and Caribbean ${ }^{62}$}

Central American and Caribbean producers should have comparative advantage in the production of coffee since they have growing areas with agro-ecological conditions to produce high quality products. Few countries in the region have made progress in exploiting this advantage. The region has potential to improve quality and penetrate high-quality specialty market segments for coffee. Quality improvement programs need to focus on on-farm production practices and postharvest practices such as coffee milling, but markets and their structure determine whether efforts to improve quality will be rewarded.

Several elements form the core of a strategy to promote coffee quality: a) ability to recognize quality in the marketing process, b) identifying the key problems affecting quality, c) defining alternatives for overcoming these problems; and d) determining policies and investments to facilitate adoption of these alternatives. To be effective, a quality enhancement strategy needs to be comprehensive and applied to the entire production and marketing chain. Work is needed in: a) identifying and supporting geographic areas with suitable agro-ecological conditions for quality production; b) promoting production of quality beans by designing and implementing broad coffee bean management and programs aimed at reducing defects; c) pursuing value-added and marketing strategies aimed at building partnerships and long-term market links; d) removing obstacles within marketing systems which prevent transmission of quality-related price signals to producers; and e) exploring promotional strategies such as e-trade and auctions, cup of excellence and market information systems.

Coffee price fluctuations and downward price trends represent a major challenge to the sector. This price variability is a major source of risk faced by all producers. Central American and Caribbean countries also are exposed to hurricanes and other severe weather problems. Competitiveness depends, in part, on the ability to deal with price and weather shocks. Risk management instruments can reduce the impacts of price and yield fluctuations and protect against negative income shocks. Effective risk management can improve the credit worthiness of the sector and increase flexibility in marketing decisions. It can also encourage a longer-term perspective and promote investments in improved technologies.

\footnotetext{
${ }^{62}$ Most of the ideas in this sub-section were adopted from Varangis, Siegel, Giovannuci, Lewin, (2003).
} 
Diversification into production of other products is often cited as a means of improving viability of production of commodities such as coffee. Diversification can contribute to increasing competitiveness of coffee producers and contribute to an exit strategy for marginal producers. Producers should consider diversifying their sources of income on and off the farm. Some might consider diversifying out of coffee, but need technical assistance to identify opportunities and smooth the transition into other uses of human and land resources. Economic, social and environmental impacts may result from increased diversification out of coffee. These impacts should be considered before promoting widespread diversification. Coffee processors and exporters should develop improved coffee products (including by-products) and other new uses of coffee to increase demand for coffee beans. Overall, coffee diversification needs to be considered in the broader context of a rural development strategy, because of complicated inter-relationships and linkages of coffee production and marketing on economic, social, and environmental systems. These systems are often exposed to external stress and are fragile.

A sustainable strategy for a competitive coffee sector should consider environment impacts of production and post-harvest activities. Sound environmental management can enhance coffee quality and productivity, profitability, competitiveness, and sustainability. Good stewardship can maintain land productivity and might provide value-added market opportunities (such as conservation coffees and environmental services). Strategies should be coordinated with environmental programs, exploring potential positive externalities between environmental protection and actions to promote coffee quality. Strategies to improve coffee quality should not have negative impacts on the environment. Social impacts of strategies, especially on hired labor, should be considered. Appropriate macroeconomic and agricultural sector policies are needed, while public sectors research and extension centers as well as partnerships with the private sector and NGOs need to be strengthened to serve this purpose.

Various programs and projects aimed at improving coffee and cocoa productivity and quality are being promoted in the Dominican Republic. These include efforts to target niche markets and incorporate environmental and social into sector planning. In the following section, we present major challenges specific to the coffee and cocoa sectors and propose strategies for dealing with them.

\section{B. Challenges and Strategies for the Coffee and Cocoa Sectors of the Dominican Republic}

The future of the coffee and cocoa sectors in the Dominican Republic is characterized by risks and uncertainty. In this section we highlight these issues, and propose strategies to address these risks. It is important to recall that the aggregate economic importance of the coffee and cocoa sectors has declined dramatically. However, many small-scale farmers produce coffee and cocoa, the sectors provide livelihoods for a significant number of producers and laborers, and both sectors have strong linkages to the manufacturing and service sectors. Historical decline relative to other agricultural sectors may continue in the future, but possibilities for growth should be explored and adjustments based on comparative advantage should be promoted. 


\title{
B.1 Macro and Agricultural Sector Policies
}

\author{
Macroeconomic Policies
}

Despite high and stable economic growth in the late 1990s, macroeconomic risks persist, and they inevitably affect the coffee and cocoa sectors. These risks include: a) the political cycle and macroeconomic management, b) fiscal vulnerability, and c) financial sector vulnerability (World Bank, 2000). Each of these factors is currently being addressed by GoDR, but is still a major concern. Of particular importance is continuing crisis in the financial sector. This crisis exacerbates problems in credit-scarce sectors such as coffee and cocoa.

Policymakers have addressed and removed anti-export policy biases. These policies negatively impacted the coffee and cocoa sectors, and included misaligned exchange rates, import and export taxes and other sources of direct and indirect distortions. Removal of these biases is an important step forward in improving these sectors' potential for being competitive in international markets. However, the persistence of import taxes on coffee and cocoa protects these sectors, but mostly benefits exporters and processors (especially large-scale exporter/processors) who can use domestic markets as a secondary market for lower quality coffee and cocoa beans, and can exercise control over producer prices. This protection inhibits efforts to improve quality.

Macroeconomic stability is an appropriate policy goal. GoDR should continue efforts to remove direct and indirect taxes on coffee and cocoa exports. The new policy of having administratively independent but publicly funded Coffee and Cocoa Councils who support the sectors is potentially a positive development. However, the effectiveness of these councils in reaching stakeholders in an efficient and equitable manner is still to be seen.

\section{Agricultural Sector Policies}

As part of its decentralization process, GoDR created an administratively autonomous Coffee Councils and proposed a similar institution for he cocoa sector. These councils are to be funded by law through government with small contributions by coffee and cocoa producers and are mandated with formulating policy and delivering public sector goods and services. The Dominican coffee and cocoa sectors are characterized, however, by dualism in production, high concentration in marketing and exports, and externalities related to labor and the environment. Producers face major exposure to external risks - such as international market prices and hurricanes. These market imperfections justify an ongoing assessment of public and private sectors roles in the sectors; the State might consider taking a more active role in addressing market failures and promoting equity within the sectors. Environmental and risk concerns alone justify more active state involvement, and pervasive poverty should be a major policy concern. Questions persist about whether "autonomous" entities charged with spending scarce sector-based resources can effectively address these concerns.

Rethinking public sector roles in the coffee and cocoa sectors needs to be viewed in the context of well-documented biases that favor other more dynamic sectors (e.g. horticultural crops, livestock). Clearly, Dominican agricultural policy increases profitability of other sectors and, as a result, resources flow into these sectors. In particular, financial resources are being crowded out 
of the coffee and cocoa sectors, creating credit scarcity. This credit scarcity is creating a shortterm perspective in the sector, slowing efforts at improving quality and leading to less effective risk management. Other factor markets supplying the sectors are similarly squeezed, particularly labor, and this squeeze reduces profitability for producers.

Both sectors have, however, received infusions of resources from government and other sources. In addition to annual budget allocations to the sectors, many post-hurricane rehabilitation projects and other "emergency assistance" (e.g., an ongoing subsidy to counter low coffee prices) have provided large amounts of resources into both sectors. These "biases" are sometimes hidden from normal budget lines, but represent an important cost to the government and donors and an important source of resources for the sectors. The efficiency, equity and impacts on long-term economic, social and environmental sustainability of these infusions are questionable and require further analysis.

The World Bank is currently working with SEA to prepare a new Agricultural Sector Strategy, which will reassess priorities, policies and strategies. The process of formulating this strategy will provide an opportunity to conduct in-depth analysis, conduct stakeholder consultations, set priorities, and design a strategy and action plan to make the agricultural sector more competitive. And importantly, also direct the agricultural sector towards achieving broader objectives such as reducing rural poverty and protecting the environment and rural society.

\section{B.2 Production and Marketing Issues}

International prices for coffee and cocoa have fluctuated and experienced a secular decline for most of the 1990s. Many developing countries are increasingly competing for markets that are growing slower than the supply. Ironically, this is one of the "positive developments" of the structural adjustment process and market and political liberalization of the 1990s. These reforms have unleashed a supply response, and world markets for many commodities are being overwhelmed. Oversupply leads to plummeting prices and a scramble to target higher priced niche markets.

As supply outstrips demand, demand for "improved" quality has become the means for producers and exporters to differentiate their products. Niche markets create price premium, but profit margins in such markets are quickly squeezed out by ever more sophisticated suppliers. As such, some markets that had been considered "niche" or "specialty" is now flooded with supply, leading to a "niche treadmill" where the challenge is to continuously identify new niches.

The Dominican Republic clearly has the potential to produce high-quality products; some areas are well-suited to coffee and cocoa production and are less exposed to diseases and pests because of distinct rainy and wet seasons. The Dominican Republic has natural conditions to produce world-class coffee and cocoa, including organic production. In contrast, Dominican coffee and cocoa do not, in general, have a good reputation for quality in international markets. This reputation persists despite recent efforts toward quality nascent attempts at improving quality in both sectors. For instance, the Dominican Republic has historically mostly exported unfermented cocoa, considered to be an inferior product compared to fermented cocoa. In recent years, Dominican cocoa producers have rapidly adopted fermentation, certified organic production, and other quality improvements in response to price incentives, and mostly through a strong producer organization and considerable donor and NGO support. As a result, the Dominican Republic is now the world's largest exporter of fermented certified organic cocoa. Some quality Dominican 
coffees - organic and non-organic - are also appearing. Structural obstacles exist in the markets for these goods and inhibit efforts to improve cocoa and coffee quality. But, when these structural barriers are removed, both sectors have the potential to respond.

For more than 30 years, coffee and cocoa marketing has been concentrated in the hands of a few firms (in the case of coffee, one firm). The marketing system was ostensibly structured to protect the many small-scale coffee and cocoa producers from potential market power. To do so, Government encouraged exporters to set a price linked to international commodity prices, subtract a margin and pay every producer a "single price" irrespective of quality. This structure allowed government to monitor marketing margins and collect taxes. Producers received the spot price (minus margins) in cash. This system has allowed many analysts to conclude that there are no "apparent distortions in the marketing system." However, the biggest problem in domestic markets is that no price differential has existed for coffee or cocoa quality. The absence of quality signals serves as a disincentive to those producers who might adopt improved production technologies and post-harvest practices. The marketing system that has existed for 30 plus years might have been good for the exporters, good for part-time small coffee and cocoa producers, good for producer/exporters, and good for a Government trying to tax coffee and cocoa exports in the past. It is, however, a major constraint on the growth of dynamic and competitive Dominican coffee and cocoa sectors in the year 2003.

The traditional manner for addressing this marketing system constraint (and to address imperfection in the financial sector) has been to encourage establishment of small scale producer associations and cooperatives that bring together these small scale groups. It was assumed that such institutions might be able to achieve scale economies and allow direct access to export markets; while offering members prices differentiated by quality and assisting in adopting practices that improve yields and quality. However, since coffee and cocoa are perennials, most producers demand credit to smooth cash flows and promote long-term investments, and many producer groups were quickly drawn into provision of financial services. With a history of politicized producer associations and cooperatives, a subsidized credit system with lax loan repayment requirements, high price and weather risks, and poor management and corruption, the financial sustainability of these producer associations and cooperatives has been limited, and many have failed. Coffee and cocoa marketing and exports exhibit some economies of scale that give an advantage to large firms or large producer groups. All these factors have limited the effectiveness of smaller sized producer groups.

The traditional "one-price" system has survived, with periodic challenges, helped partly by the Government's direct or indirect assistance during time of crises. For the sectors to be competitive in the future, there is a pressing need to reform the Dominican marketing and finance systems, and price setting mechanisms for coffee and cocoa. Development of viable producer associations and cooperatives should be promoted; however, failures from the past should be studied and avoided in the future. Other institutions for price discovery and market transactions need to be explored. The new commodity exchange BOLSAGRO, for example, could potentially act as a clearinghouse that brings buyers, sellers and financiers together in a physical or virtual marketplace for coffee and cocoa. 


\section{B.3 Land, Labor and Finance Issues}

Land, labor and finance help determine the competitiveness of both the coffee and cocoa sectors. Land issues include: a) distribution, b) security of titles, c) quality and productivity, and d) impacts of land use on the environment. The recent Country Assistance Strategy highlights the urgency of dealing with land issues in Dominican Republic (World Bank, 1999).

The skewed distribution of land in the Dominican Republic supports a highly dualistic system in the coffee and cocoa sectors. Many poor Dominicans produce coffee and cocoa on small holdings. Even under ideal conditions, they could not support their households solely through coffee or cocoa production, but coffee and cocoa incomes contribute to their income-generating portfolio. Other sources of income for these households may also be linked to the sectors; in some cases they work as laborers for larger producers. These small-scale producers have little ability or incentive to invest in their plantations when prices are low, and this generates a cycle of low yield and poor quality. They maintain their plantations to keep a claim on their (often untitled land) and the trees generate some cash to supplement household incomes. Other producers operate on a much larger scale and are highly commercialized in nature. The challenge to coffee and cocoa policy makers is to design a strategy with this dualism in mind. One set of policies, such as publicly supported technical and marketing assistance, provision of micro financial services, emergency micro insurance programs, might be designed to promote equity in the sector and improve the viability of small scale producers. Another set, such as research into labor-saving technologies, self-financing of producer services, would be geared toward the largerscale producers. Decisions about the appropriate policy direction must consider policy objectives and trade-offs: equity and/or increased efficiency and international competitiveness.

Insecure land titles have often been raised as a problem faced by both sectors, especially in the context of linkages to financial markets and the lack of collateral. Insecure tenure can constrain access to credit from formal institutions. Insecure tenure can also lead to under-investment in the sector. Both these problems need further investigation. Land titling is a time-consuming and costly means of guaranteeing loans and if insecure tenure is truly a binding constraint to financiers, alternative forms of securing loans might be explored. The existing credit system for coffee and cocoa producers is mainly based on credit linked to marketing; producers receive advances on their harvest. In such a system, exporters borrow from commercial banks, and insecure tenure on the part of producers may not be a constraint. This is not inherently a "bad" system, if the lending terms mirror commercial lending terms. However, with high interest rates, producers need to consider alternative means of financing, such as microfinance, and selffinancing. One means of improving the capacity for self-financing and risk management is diversified on- and off-farm economic activities. Public and private participants in both sectors are actively considering diversification, but more research is needed to understand the economic, social and environmental dimensions of diversification (as highlighted in Varangis, Siegel, Giovannuci, Lewin, 2003).

The authors have not found strong evidence that insecure tenure is inhibiting investments in the coffee or cocoa sectors. In fact, discussions with experts indicate the opposite might be true: insecure tenure may promote investment in coffee and cocoa trees as a means of establishing claims on the land. One hypothesis that would generate support for more active land titling is that tenure problems slow investment and inhibit the sectors from improving quality and productivity. Our regressions (with an admittedly small sample size) found no statistical evidence of this problem, but the data were not collected with such a hypothesis in mind. 
As new opportunities opened in the 1990s, many children of coffee and cocoa producers found alternative employment in other agricultural activities or non-agricultural activities, and many have migrated. Out-migration of labor has not raised wages for coffee and cocoa laborers, mainly because of inexpensive Haitian migrant labor in the coffee sector. While some medium and larger sized coffee and cocoa producers have been adopting new higher yielding production technologies that require more hired labor, the pool of Haitian labor has served as a disincentive to introduce more labor-efficient production and post-harvest practices. The high cost of credit has also been as a disincentive to invest in labor-saving technologies. Dependence on low-cost labor could be a constraint on future competitiveness, especially if reports of a tightening rural labor markets are true. In any case, considering all the household labor used by small producers, and the hired Haitian labor used by other producers, it is difficult to get a grasp on the costs of coffee and cocoa production and harvesting because of the high labor share in such costs.

Better understanding of the structure and problems in rural labor markets is needed to formulate effective policy. Data on rural labor are virtually non-existent, so that even basic information is impossible to find. Efforts to collect data and support rural labor market research should be a major priority. With such information, government would be better positioned to have a coherent labor market strategy. Government might consider labor-contracting mechanisms as a means of ensuring a more reliable supply of guest workers, especially for small-scale producers. With more transparent contracting that guarantees rights of employees and obligations of employers, efficient supplies of higher-quality labor would benefit quality improvement efforts in both sectors.

Markets for agricultural inputs in the Dominican Republic often exhibit imperfections that inhibit efficient allocation of resources (which are exacerbated by policy biases favoring other agricultural and non-agricultural sectors). Credit, land and labor markets are characterized by high transactions costs, imperfect information, and imperfect enforcement of property rights. Institutional reform to benefit these markets might include government provision of information, support for pilot programs (such as micro finance), provision of technical support and agricultural research, and transparent enforcement of property rights. In addition, as noted throughout the report, financial sector reform is necessary for all agricultural sectors and especially the creditconstrained coffee and cocoa sectors.

\section{Commodity Price and Weather Related Risks}

International prices of coffee and cocoa have been volatile during the 1990s, and major hurricanes struck Dominican Republic in 1979, 1987, and 1998. These risks are transmitted through the entire production-finance-marketing chain, and have broader economy-wide effects. Pervasive risk constrains adjustment in the sectors and requires attention to risk management instruments.

A recent study by the World Bank's Commodity Risk Management Group (CRMG) highlights commodity price risks in the Dominican coffee and cocoa sectors, and proposes the introduction of risk management instruments based on international commodity exchanges (World Bank, 2002a). Significant discussion ensued with representatives of the coffee and cocoa sectors in the Dominican Republic about the possibility of piloting such commodity price insurance.

CONOCADO expressed interest in a pilot project for cocoa, as a means of securing more 
commercial credit to on-lend to its members, but operations of this risk management instrument need fine-tuning.

There is a pressing need for investments in institutions and infrastructure to help improve longterm disaster preparedness, to reduce vulnerability to risks, and to improve risk mitigation and coping mechanisms (World Bank, 1998). A background paper for the recent Poverty Assessment for Dominican Republic suggests the need to establish of a hurricane insurance fund (see Lopez, 2001). The most recent CAS also highlights the need for natural disaster vulnerability and mitigation strategies and investments (World Bank, 1999). A new type of weather insurance called "weather-based index insurance" might be appropriate to conditions Dominican Republic, since the instruments can protect against hurricanes and droughts (Skees, Varangis, Larson and Siegel, 2002). This type of insurance can be tailored and delivered to producers and the broader rural population. It can also be purchased at the meso (e.g., community, MFIs, banks) and macro (e.g., national government) levels. AGRODOSA, the new agricultural insurance company should take the lead in exploring the possibility of providing crop insurance for coffee and cocoa producers; drawing on the experience of Partner Re, who is providing technical assistance.

\section{Environmental Impacts}

Many coffee and cocoa producing areas are located in environmentally sensitive regions. Land use practices, including production technologies and post-harvest practices cocoa can generate significant positive and negative externalities. Traditional coffee and cocoa production practices generally have positive impacts on critical watersheds. Some of the more "advanced" technologies, sometimes promoted for coffee and cocoa, can have fewer environmental benefits and create more external costs than traditional technologies. Furthermore, some of these practices lead to deforestation, soil erosion and watershed degradation, and also increase vulnerability to natural disasters (World Bank, 1999). Ongoing dialogue between the World Bank and GoDR on environmental and agricultural sectors strategies provides an ideal opportunity to integrate environmental concerns into coffee and cocoa sector strategies. Coordination of environmental and agricultural strategies should help raise the profile of environmental impacts of coffee and cocoa production. A watershed management approach might be adopted, that considers the complex economic-social-environmental inter-relationships in a given area. A watershed approach should be integrated with understanding of how the sectors are linked to local and regional economies, and to providing appropriate price signals and incentives to internalize externalities. Such an approach will allow better decision making by showing how coffee and cocoa production affects the environment and regional economic welfare. A pilot project to integrate investigation of household-level livelihood strategies with community-level planning and a broader regional watershed approach would be very timely.

\section{E. Conclusion: Toward a Strategy for the Coffee and Cocoa Sectors}

Based on the above, if the objectives of the government are poverty reduction, environmental protection and overall well-being of rural society, it is critical to move beyond a commodityspecific approach to a broad focus on households, regions and environments where coffee and cocoa are currently being grown. While policies and programs can help bolster the economic viability of both commodity sectors, their ultimate sustainability depends on the mosaic of linkages between households and their economic, social and environmental context. However, more information is needed before such a holistic approach can be adopted. More information is 
needed on households and their diversified activities. Information is also needed on the relationship between household economic activities and the environment.

The public sector has a clear role in defining and enforcing property rights, providing the appropriate incentive structure, ensuring transparency and equality of access, and promoting broad-based improvements in well being. It has a responsibility to allow community demands to form the basis of local and regional development efforts. A policy of community-led development will help ensure that local priorities are included in development plans. A program of community-led development will move away from a narrow commodity focus and instead incorporate information about the diverse set of economic and social activities that constitute household livelihood strategies, and how they interact with environmental concerns. It is also critical to consider broader environmental concerns of the greater society living in the sensitive watersheds where coffee and cocoa are produced. By strengthening appropriate components of these strategies, policies should promote improvements in well being that are equitable, economically sound, and socially and environmentally friendly. Thus, the real question to be asked is what are the optimal policies and investments that will allow households and communities in coffee and cocoa producing regions to maximize social objectives. This might include coffee and cocoa production activities. The question should not necessarily be how to preserve coffee and cocoa production per se. To adopt this broader rural development approach, there are still important information gaps to fully understanding and appreciating the complex mosaic of issues, and for identifying the appropriate roles of government, the private sector, international development agencies, and NGOs. 


\section{References}

Auffret, P. (2003) "Catastrophic Insurance Market in the Caribbean Region: Market Failures and Recommendations for Public Sector Interventions.” Development Research Group, Rural Development. Working Paper Series No. WPS 2963. The World Bank: Washington, D.C. see www.worldbank.org/research

Buchanan, S. (2003) OsterDowJones Commodity News, February 2, 2003

Buzzanell, P. (2002) "Caribbean Coffee - Initiatives to Stabalilize Supply and Improve Quality." Peter Buzzanell and Associates. November.

CATIE (2002) "Proyecto Agroforestal para la Diversificacion Sostenible, La Competitividad y El Reconocimiento de Servicios Ambientales del Cultivo de Café en Republica Dominicana: Research Proposal.” May 31.

CODOCAFE (2003) “Café: Resultados de Investigación.” Santo Domingo.

de Ceara, I.A. (1986) "Land Tenure and Agroforestry in the Dominican Republic." Social Forestry Network. Network Paper 3d. Overseas Development Institute (ODI): London. http://www.odifpeg.org.uk/publications/rdfn/3/rdfn-3d.pdf

Central Bank of Dominican Republic (various) see website www.bancentral.gov.do

CRMG (2003) "Analyses of Data from Survey of Coffee and Cocoa Producers in the Dominican Republic" draft paper prepared by J. Alwang and P. Siegel for the Commodity Risk Management Group, Agriculture and Rural Development Department, The World Bank: Washington, D.C. mimeo.

ECLAC (2001). "Panorama de la Agricultura de America Latina y el Caribe.” December. Prepared by ECLAC and IICA. See ECLAC website: cepal.org

ECLAC (2002) Centroamerica: El impcato de la caida de los precios del Café." Prepared by M. Flores, A. Bratescu, J. O. Martinez, J. Oviedo, and A. Acosta. ECLAC Studies and Perspectives: México City. see ECLAC website: cepal.org

E.D.E. Consulting (2002) "Diagnostic for Coffee Processing in the Dominican Republic ("Esperanza Agroindustrial, S.A." Prepared for the Association of Coffee Farmers "La Esperanza" and the Centre for Develiopment of Industries. Hamburg. See the EDE website: http://www.ede-coffee.de/projects_and_studies/Projects

The Economist (2001) “Country Profile 2001: Dominican Republic, Haiti, Puerto Rico.” The Economist Intelligence Unit: London.

FAO (2003) "Coffee Projections to 2005" FAO website: www.fao.org/es/ESC/esce/eser/coffee/coffeePe.htm

Fitch , Inc. (2002) Fitch Ratings: Dominican Republic Commercial Banks - 2001 Review.” May. Copyright by Fitch, Inc. and Fitch Ratings. 
Fleischer, G. (2002) "Toward More Sustainable Coffee: Consumers fuel demand for more sustainable agriculture." Agriculture Technology Notes, No. 30. The World Bank: Washington, D.C.

Gomez, T. (2001) “Gasto Publico Para El Deasarrollo Agrícola Rural en la Republica Dominica (1991-2000)." Report prepared for the FAO. See FAO website: fao.org....

Gomez, T. (2002) "Financial Structure and Financing of the Coffee and Cocoa Trade." $2^{\text {nd }}$ draft. draft paper for the Commodity Risk Management Group, Agriculture and Rural Development Department, The World Bank: Washington, D.C. mimeo.

IADB (2001) "Política Agroclimentaria, Competitividad y Pobreza Rural: Documento de Trabajo.” Departamento Regional de Operaciones II. February.

ICO (2003) see the International Coffee Organization's website: www.ici.org

JAD (2002a) "BOLSAGRO incia operaciones". Agroempresa, Ano XIV, No. 1, Jan.-Mar., p.3-4.

JAD (2002a) "Mercados directos de productores agropecuarios". Agroempresa, Ano XIV, No. 1, Jan.-Mar., p.24.

Lopez, R. (2001) "Rural Poverty in Dominican Republic: Market Failures, Government Failures and New Policies." In World Bank (2001) "Dominican Republic Poverty Assessment: Poverty in a High-Growth Economy (1986-2000).” Volumes II. Report No. 21306-DR. December.

Washington, D.C.

Mercedes, F. (2002) "Estudio Preliminar para Determinar El Costs de Produccion de un Quintal de Café en la Republica Dominicana.” Prepared for CODOCAFE: Santo Domingo.

Migration International Pty. Ltd. (2002) "Immigration Laws : April 2000 - Number \#9.“ http://www.migrationint.com.au/news/slovenia/apr_2000-09mn.html

Pollner, J.D. (2002) "Catastrophic Risk Management: Using Alternative Risk Financing and Insurance Pooling Mechanisms.” ?” Development Research Group, Rural Development. Working Paper Series No. WPS 2560. The World Bank: Washington, D.C. see www.worldbank.org/research

Ponte, S (2002) "The Latte Revolution? Regulation, Markets and Consumption in the Global Coffee Chain." World Development, Vol. 30, No. 7, pp. 1099-1122.

Poyo (2003) "Report on the Banking Services to the Agricultural Sector and Financial and Institutional Analysis of CONACADO" Report prepared for the Commodity Risk Management Group, The World Bank: Washington, D.C. March. mimeo

Raynolds, L.T. (2002) "Wages for Wives: Renegotiating Gender and Production Relations in Contract Farming in the Dominican Republic." World Development, Vol. 30, No. 6, pp. 783-798.

Schiff, M. (2001) "The Effect of Macroeconomic Policies on Rural Poverty in the Dominican Republic". In World Bank (2001) "Dominican Republic Poverty Assessment: Poverty in a HighGrowth Economy (1986-2000).” Volume II. Report No. 21306-DR. December. Washington, D.C. 
Siegel, P.B. and J. Alwang 1999. "An Asset-based Approach to Social Risk Management: A Conceptual Framework.” Social Protection Discussion Paper, No. 9926. Washington, D.C.: The World Bank. See www.worldbank.org/SP.

Skees, J., P. Varangis, D. Larson, and P.B. Siegel (2002) "Can Financial Markets be Tapped to Help Poor People Cope with Weather Risks?” Development Research Group, Rural Development. Working Paper Series No. WPS 2812. The World Bank: Washington, D.C. see www.worldbank.org/research

SOFRECO (2001) "Estudio de Factibilidad del Proyecto de Producción y Promocion de Cafes Especiales.”Report produced for the Secretariado de la Presidencia, Republica Dominicana.

Valdes, A., B. Schaeffer, and J. de los Santos (1995) Surveillance of Agricultural Prices and Trade: A Handbook for the Dominican Republic. World Bank Technical Paper Number 267. Washington, D.C.

Varangis, P. (1999) "Coffee Pricing Policies in the Dominican Republic.” International Commodity Markets, International Economics Department. Working Paper Series No. WPS 211. The World Bank: Washington, D.C.

Varangis, P., D. Larson, and J.R. Anderson (2002) "Agricultural Markets and Risks:

Management of the Latter, Not the Former." Policy Research Working Paper Number 2793. The World Bank: Washington, D.C. www.worldbank.org/research

Varangis, P., P. Siegel, D. Giovannuci, and B. Lewin (2003) "Dealing with the Coffee Crisis in Central America: Impacts and Strategies," Development Research Group, Rural Development. Working Paper Series No. WPS 2993. The World Bank: Washington, D.C. See www.worldbank.org/research

World Bank (1981) ) Dominican Republic Cocoa and Coffee Development Project: Staff Appraisal Report. Report 3379-DO. Washington, D.C.

World Bank (1991) "Project Completion Report Dominican Republic Cocoa and Coffee Development Project.” Loan 2023-DO. Report 9600. May. Washington, D.C.

World Bank (1995) "Staff Appraisal Report Domincan Republic Irrigated Land and Watershed Management Project." Report 122233-DO. January Washington, D.C.

World Bank (1998) "Project Appraisal Document on a Proposed Loan to the Dominican Republic for a Hurricane Georges Emergency Recovery Project.” Report No. 18648. December. Washington, D.C.

World Bank (1999) "Country Assistance Strategy for the Dominican Republic." Report No. 19393-DR. June. Washington, D.C.

World Bank (2000) "Dominican Republic Social and Structural Policy Review." Volumes I \& II. Report No. 20192-DR. March. Washington, D.C.

World Bank (2001) "Dominican Republic Poverty Assessment: Poverty in a High-Growth Economy (1986-2000).” Volumes I \& II. Report No. 21306-DR. December. Washington, D.C. 
World Bank (2002a) "Dominican Republic: Coffee and Cocoa Phase II Report.” September. Agriculture and Rural Development, Commodity Risk Management Group, The World Bank: Washington, D.C. September. mimeo. see www.itf-commrisk.org

World Bank (2002b) "Mexican Coffee Sector and the Coffee Crisis." Latin American and the Caribbean Regional Office and Agriculture and Rural Development Department. The World Bank: Washington, D.C. November.

World Bank (2002c) "Columbia Coffee Sector Study." Latin American and the Caribbean Regional Office and Agriculture and Rural Development Department. The World Bank:

Washington, D.C. July.

World Bank (2003) "Dominican Republic National Environmental Policy Reform Project: Implementation Completion Report.” Report No. 2582. The World Bank: Washington, D.C. 


\section{ANNEX \\ Overview of the World Bank's Cocoa and Coffee Project 1982-1989}

The World Bank funded a Cocoa and Coffee Sector project from 1982 to 1989. The project was a \$28 million loan (of which \$24 was actually disbursed), a rather sizeable project for the coffee and cocoa sectors of Dominican Republic (World Bank, 1981). It is interesting to review the major objectives and the performance of the project because many of the very same issues are still relevant. Furthermore, the Project Completion Report (World Bank, 1991) considered it an "unsatisfactory project", and it is important to learn from this past experience.

\section{Project Objectives: Based on the Project Appraisal Report (World Bank, 1981)}

Following extensive damage in 1979 by Hurricanes David and Fredrick, the Government of Dominican Republic requested assistance from the World Bank for rehabilitation and replanting of cocoa and coffee farms. In addition to recovery efforts, the project sought to increase incomes of small scale cocoa and coffee producers and to increase production and export of these commodities by: a) improving productivity, b) improving the quality of coffee and cocoa beans through the adoption of improved tree varieties and improved production and post-harvest practices, c) increasing payments to producers based on differentiated coffee and cocoa quality, and d) improving the market bargaining power of small producers through the formation of producer associations and cooperatives. These objectives were to be achieved by providing farmers with: a) technical assistance through SEA, and b) credit through BA to finance on-farm development plans. SEA and BA were the project's implementing agencies.

For the cocoa sector, particular objectives were to: a) rehabilitate 4,600 ha (2,000 farms) and replant 6,400 ha $(2,800$ farms $)$, b) provide 1,000 fermentation boxes and 300 sun-drying facilities for improved post-harvest practices, and c) establish 22 tree nurseries with improved tree varieties by SEA. For the coffee sector, particular objectives were to: a) replant 5,000 ha (5,000 farms), and b) establish 52 nurseries by SEA and 520 private coffee nurseries.

It is also important to point out that this report claims that despite the small number of firms controlling coffee and cocoa exports that: "Recent surveys carried out by the Cocoa and Coffee Departments show that farmgate prices average $67 \%$ of export prices (New York quotations) in the case of cocoa and $72 \%$ in the case of coffee. Although these relatively high ratios point to no major or unusual inefficiencies in cocoa or coffee marketing, SEA is carrying out a program to enable farmers to participate more actively in marketing (WB, 1981, p.28)." Furthermore: "In the case of cocoa, improvements in processing ... should have a larger impact on increasing farm incomes than possible improvements in marketing alone (WB, 1981, p,28)."

\section{Project Performance: Based on the Project Completion Report (World Bank, 1991)}

The project encountered difficulties in achieving its objectives because SEA and BA performance during implementation was unsatisfactory, due mainly to their increasingly weak institutional capacity. A project risk, which was not foreseen at appraisal and therefore which was not taken into account in the design of the project, was the weak implementation capacity of SEA and BA, which seriously constrained the project's implementation. In particular, the provision of technical assistance was deemed unsatisfactory, for a variety of reasons. Interestingly, in March 1987, GoDR launched a parallel, but highly subsidized, coffee and cocoa rehabilitation program that "competed" with the World Bank project and sent conflicting signals to the sectors. After several 
years of slow disbursements, the project was actually "saved" by a hurricane. In the wake of Hurricane Emily in September 1987, the project was amended to accommodate Emergency Relief Measures through the quick disbursement of funds for purposes not originally intended in the project loan.

During the life of the project, there was demand for subloans for cocoa sun drying facilities, but less demand for fermentation boxes for cocoa. Also, the demand for cocoa rehabilitation and replanting, and processing facilities was less than expected. The main reason for the lack of demand for the quality enhancing fermentation boxes was that there was no price premium for better quality fermented cocoa (Hispaniola type), versus the lower quality unfermented (Sanchez type) cocoa. Also, for coffee, there was little demand for improved processing (depulping) facilities because of the lack of differential price based on quality. In addition, demand for shortterm credit for coffee marketing was less than expected. Furthermore, producer associations and cooperatives had limited success, due to capacity constraints and the checkered history of performance by such groups that were initiated by Government.

The project was also negatively impacted by the fact that international prices fell for coffee (by $50 \%$ ) and cocoa (by 25\%). In addition, there were constraints from distorted macro policies, in particular export taxes, interest rates and exchange rates, and from inefficient implementation agencies, SEA and BA.

Also, expected increases in productivity were not achieved, although they were still significantly better than the pre-project situation. Field surveys comparing yields between appraisal estimates and actual yields (at full development, year 5 and beyond) found: for coffee replanting, $670 \mathrm{~kg} / \mathrm{ha}$ versus $900 \mathrm{~kg} / \mathrm{ha}$ (about $75 \%$ of target), for cocoa rehabilitation $500 \mathrm{~kg} / \mathrm{ha}$ versus $560 \mathrm{~kg} / \mathrm{ha}$ (about $90 \%$ of target), and for cocoa replanting, $550 \mathrm{~kg} / \mathrm{ha}$ versus $680 \mathrm{~kg} / \mathrm{ha}$ (about $80 \%$ of target). Nevertheless, the project led to substantial incremental cocoa and coffee production. And, it was concluded that this was accomplished: "In spite of lower yields than expected, and lower cocoa and coffee prices, investments in cocoa and coffee were still attractive to farmers". (World Bank, 19991, p.7)

On a positive note, it was concluded that environmental impacts were positive (or at least, not negative), with the claim that the project did help sustain the physical environment in the project areas through maintenance of a permanent canopy of coffee and cocoa, thereby contributing to soil and water conservation. ${ }^{63}$

Also, there was an isolated success in getting cocoa producers to ferment their beans. GTZ was working to improve the quality of cocoa for export and organized three "blocks" of cocoa producers associations (with another two in the course of establishment) to improve their negotiating position vis-à-vis exporters and to reduce the role of intermediaries in the marketing process. These association blocks were already upgrading the quality of cocoa and receiving a positive price differential for their Hispaniola cocoa. This work by GTZ has continued, and as will be discussed in Chapter IV, these efforts are finally demonstrating significant results via the cocoa producer cooperative CONACADO.

\footnotetext{
${ }^{63}$ This veracity of this claim, however, is a little puzzling considering that some of the cultural practices adopted by coffee producers - such as pure stand coffee plantings with higher applications of agrichemicals - would intuitively seem to, at least, lessen the positive environmental impacts attributed to the project. Authors Note.
} 
Recommended follow-up actions outlined in the Project Completion Report included: a) develop autonomous Coffee and Cocoa Commission responsible for the development of the sectors, and the provision of extension services, b) limit SEA's involvement to their control and regulatory functions, and promote private sector enterprises to produce seeds and improved planting materials (as opposed to SEA), c) introduce policy reforms for interest rates, exchange rates, and export taxes, d) improve BA's loan evaluation and examination units, its accounting systems and collections, and address financial sector distortions, e) provide medium term credit for coffee producers in order to maintain the DR's position in world coffee markets, and f) continue investing in processing and marketing to improve the quality of Dominican coffee and cocoa.

As we will see in this report, more than 30 years after the inception of the World Bank's Cocoa and Coffee Sector project, many of the same issues and challenges remain. On the other hand, many of the recommended actions have also taken place - especially with respect to removing policy distortions that negatively impacted Dominican Republic's comparative advantage vis-àvis external markets. 


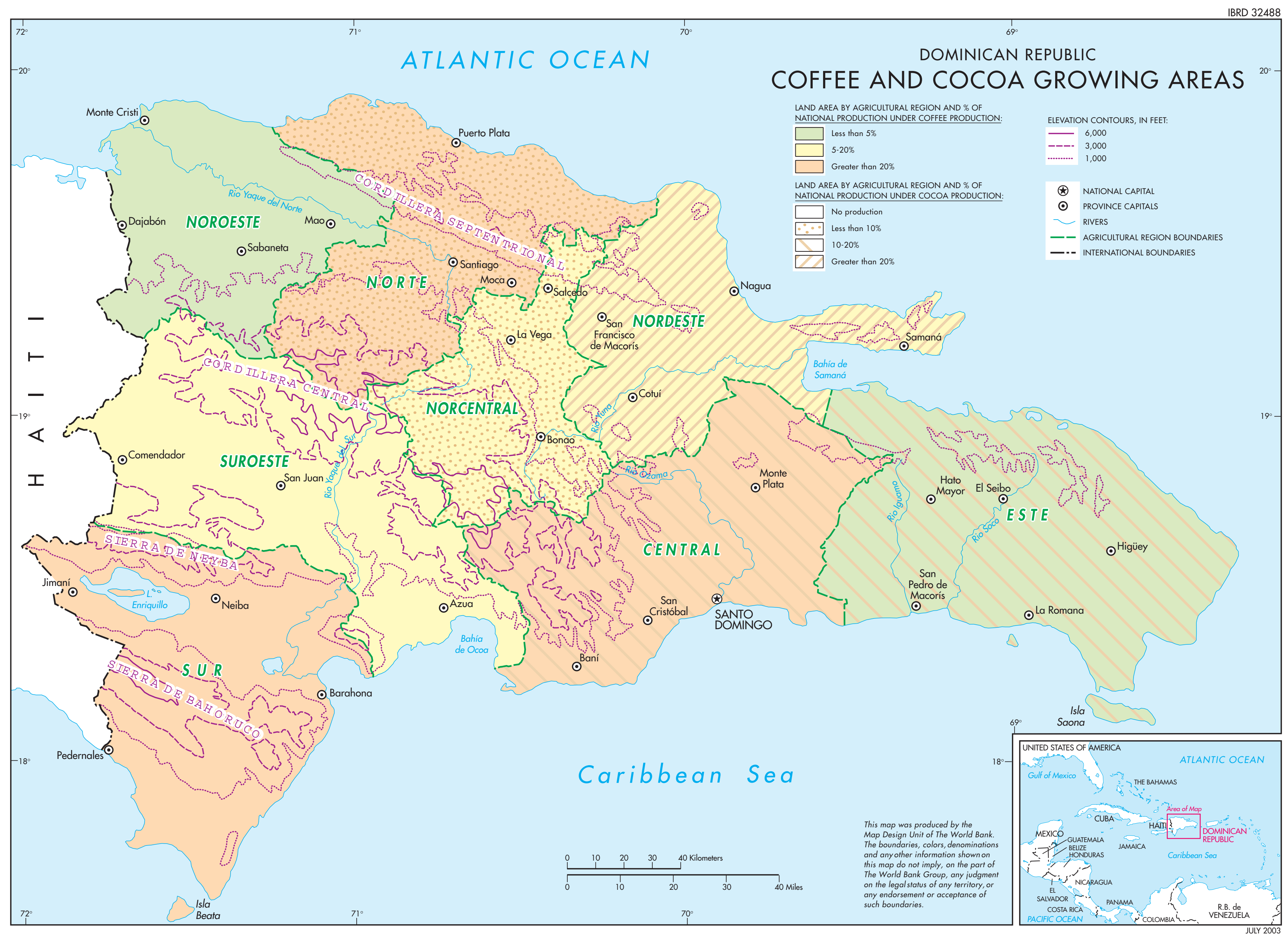

